c. 2

US Army Corps of Engineers

Waterways Experiment

Station
US-CE-C Property of the

United States Government

\title{
Site Characterization and Analysis Penetrometer System (SCAPS) Field Investigation at the Building 4020 Site, Aberdeen Proving Ground, Maryland
}

by William M. Davis, Landris T. Lee, Jr., Jeff F. Powell

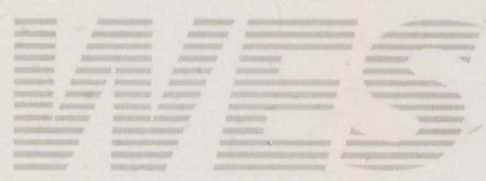

Approved For Public Release; Distribution Is Unlimited

Research Library

US Army Engineer Waterways

Experiment Station

Vicksburg, Mississippi 
The contents of this report are not to be used for advertising, publication, or promotional purposes. Citation of trade names does not constitute an official endorsement or approval of the use of such commercial products. 


\section{Site Characterization and Analysis Penetrometer System (SCAPS) Field Investigation at the Building 4020 Site, Aberdeen Proving Ground, Maryland}

by William M. Davis, Landris T. Lee, Jr., Jeff F. Powell

U.S. Army Corps of Engineers

Waterways Experiment Station

3909 Halls Ferry Road

Vicksburg, MS 39180-6199

Final report

Approved for public release; distribution is unlimited

Prepared for U.S. Army Corps of Engineers

Washington, DC 20314-1000 


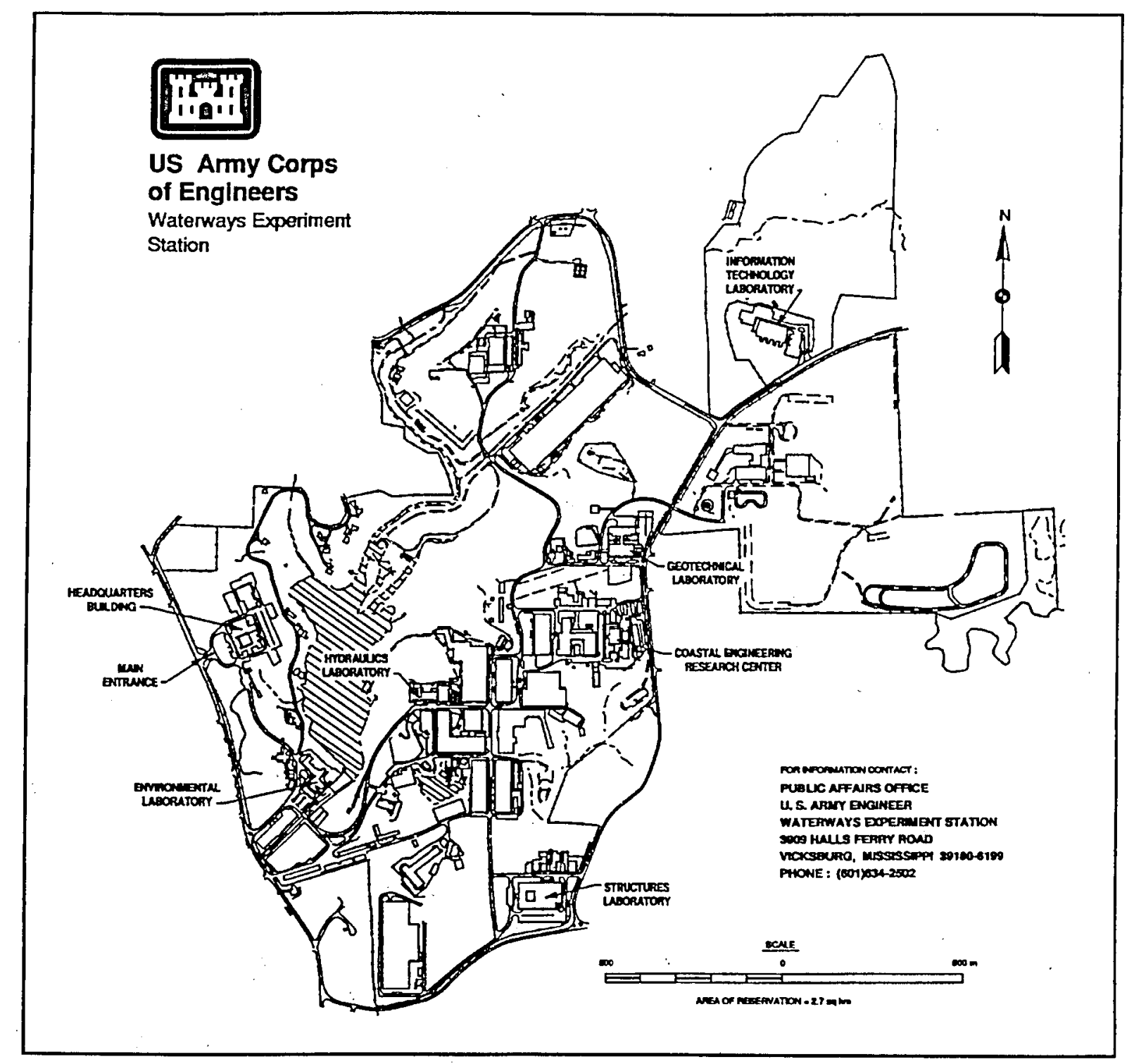

Waterways Experiment Station Cataloging-in-Publication Data

Davis, William $M$.

Site Characterization and Analysis Penetrometer System (SCAPS) field investigation at the Building 4020 Site, Aberdeen Proving Ground, Maryland / by William M. Davis, Landris T. Lee, Jr., Jeff F. Powell ; prepared for U.S. Army Corps of Engineers.

92 p. : ill. ; $28 \mathrm{~cm}$. - (Technical report ; EL-96-17)

Includes bibliographic references.

1. Penetrometer - Evaluation. 2. Soil pollution - Environmental aspects. 3. Soil remediation. I. Lee, Landris T. II. Powell, Jeff F. III. United States. Army. Corps of Engineers. IV. U.S. Army Engineer Waterways Experiment Station. V. Environmental Laboratory (U.S. Army Engineer Waterways Experiment Station) VI. Tri-Service Site Characterization and Analysis Penetrometer System Program. VII. Title. VIII. Series: Technical report (U.S. Army Engineer Waterways Experiment Station) ; EL-96-17.

TA7 W34 no.EL-96-17 


\section{Contents}

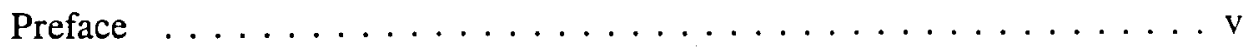

Conversion Factors, Non-SI to SI Units of Measurement $\ldots \ldots \ldots \ldots$ vii

1 -Introduction $\ldots \ldots \ldots \ldots \ldots \ldots \ldots \ldots \ldots \ldots$

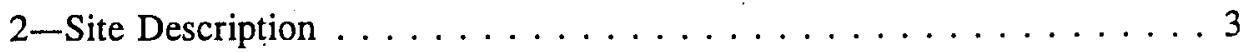

3-Investigation Equipment and Procedures $\ldots \ldots \ldots \ldots \ldots \ldots$

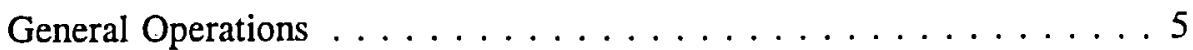

Penetrometer Fluorescence Verification . . . . . . . . . . 9

4-Results and Discussion $\ldots \ldots \ldots \ldots \ldots \ldots \ldots$

Soil Classification Measurements . . . . . . . . . . . . 11

Subsurface Petroleum Detection Using the SCAPS POL Sensor . . . . 19

POL Sensor Verification $\ldots \ldots \ldots \ldots \ldots \ldots \ldots \ldots$

5-Summary and Conclusions $\ldots \ldots \ldots \ldots \ldots \ldots \ldots \ldots \ldots$

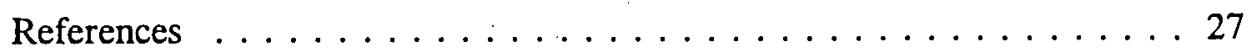

Appendix A: SCAPS POL Sensor Panel Plots $\ldots \ldots \ldots \ldots \ldots \ldots$ A1

Appendix B: List of Demonstration Participants . . . . . . . B1

SF 298

\section{List of Figures}

Figure 1. Site map showing Building 4020 within APG . . . . . . . 2

Figure 2. SCAPS investigation site near Building $4020 \ldots \ldots \ldots$

Figure 3: The SCAPS system $\ldots \ldots \ldots \ldots \ldots \ldots$

Figure 4. Typical SCAPS panel plot .............. 10

Figure 5. View of site soil stratigraphy $\ldots \ldots \ldots \ldots 13$

Figure 6. View of SCAPS POL sensor response, low intensity . . . . 15

Figure 7. View of SCAPS POL response, high intensity $\ldots \ldots \ldots 17$ 
Figure 8. Comparison between TRPH and POL sensor response . . . . 23

Figure 9. Comparison between PAH-NAPH and POL sensor

response . . . . . . . . . . . . . . . 24 


\section{Preface}

This report was prepared by the Environmental Laboratory (EL) of the U.S. Army Engineer Waterways Experiment Station (WES), Vicksburg, MS. The research was funded under the Tri-Service Site Characterization and Analysis Penetrometer System Program by the U.S. Army Environmental Center, Work Unit A5-3, "Demonstration of Rapid Site Characterization with SCAPS POL Sensor.” The Program is managed by Dr. John Cullinane, WES, and Mr. George Robitaille was the Technical Monitor for the U.S. Army. Environmental Center. Personnel who cooperated in the execution of the study and the preparation of this report include Dr. William M. Davis, Principal Investigator, Ecosystem Processes and Effects Branch (EPEB), Environmental Processes and Effects Division (EPED), and Mr. Karl Konecny of the Environmental Engineering Division (EED), EL; Mr. Jeff Powell, Instrumentation Services Division (ISD), Information Technology Laboratory (ITL); Mr. Landris Lee, Earthquake Engineering and Geophysics Division (GG), Geotechnical Laboratory (GL); and Mr. Donald Harris, Public Works Division, WES.

This report was reviewed by Dr. Ernesto Cespedes, Chief, Environmental Sensing Branch, EED, and Ms. Cynthia Price, EPED. The report was prepared under the general supervision of Dr. Richard E. Price, Chief, EPEB; Mr. Joseph Curro, Chief, Engineering Geophysics Branch, GG; Mr. Donald L. Robey, Chief, EPED; Dr. Arley G. Franklin, Chief, GG; Dr. John W. Keeley, Director, EL; and Dr. William F. Marcuson III, Director, GL.

At the time of publication of this report, Dr. Robert W. Whalin was Director of WES. COL Bruce K. Howard, EN, was Commander. 
This report should be cited as follows:

Davis, W. M., Lee, L. T., Jr., and Powell, J. F. (1996). "Site characterization and analysis penetrometer system (SCAPS) field investigation at the Building 4020 site, Aberdeen Proving

Ground, Maryland," Technical Report EL-96-17, U.S. Army

Engineer Waterways Experiment Station, Vicksburg, MS.

The contents of this report are not to be used for advertising, publication, or promotional purposes. Citation of trade names does not constitute an official endorsement or approval of the use of such commercial products. 


\section{Conversion Factors, Non-SI to SI Units of Measurement}

Non-SI units of measurement used in this report can be converted to SI units as follows:

\begin{tabular}{|l|l|l|}
\hline Multiply & By & To Obtain \\
\hline \hline feet & 0.3048 & meters \\
\hline gallons (U.S. liquid) & 3.7854 & liters \\
\hline
\end{tabular}





\section{Introduction}

The U.S. Army Environmental Center sponsored a site characterization conducted by the U.S. Army Engineer Waterways Experiment Station (WES) at a designated petroleum-contaminated site within the U.S. Army Aberdeen Proving Ground (APG), Maryland (Figure 1). The objective was to delineate subsurface petroleum contamination using the petroleum, oil, and lubricant (POL) sensor of the Tri-Service site characterization and analysis penetrometer system (SCAPS). SCAPS with the POL sensor is capable of simultaneously determining subsurface stratigraphy and POL contamination.

SCAPS was deployed at APG from 17 February through 3 March 1995. The site that was characterized is near APG Building 4020 in the vicinity of previously removed $\# 2$ fuel oil underground storage tanks (USTs). Data from a total of 61 subsurface penetrations (51 sensing and 10 sampling penetrations) were collected during the time period (Appendix A). The maximum depth of sensor penetration achieved for data collection during the site investigation was $67 \mathrm{ft}^{1}$ below ground surface.

In addition to the site investigation using the SCAPS POL sensor, there were demonstrations of SCAPS capabilities for 2 days at the site. A list of demonstration participants is given in Appendix B. A local citizens group, APG personnel, and regulatory representatives attended the demonstrations. These demonstrations were a part of the continuing effort to inform user communities of SCAPS capabilities.

1 A table of factors for converting non-SI units of measurement to SI units is presented on page vii. 


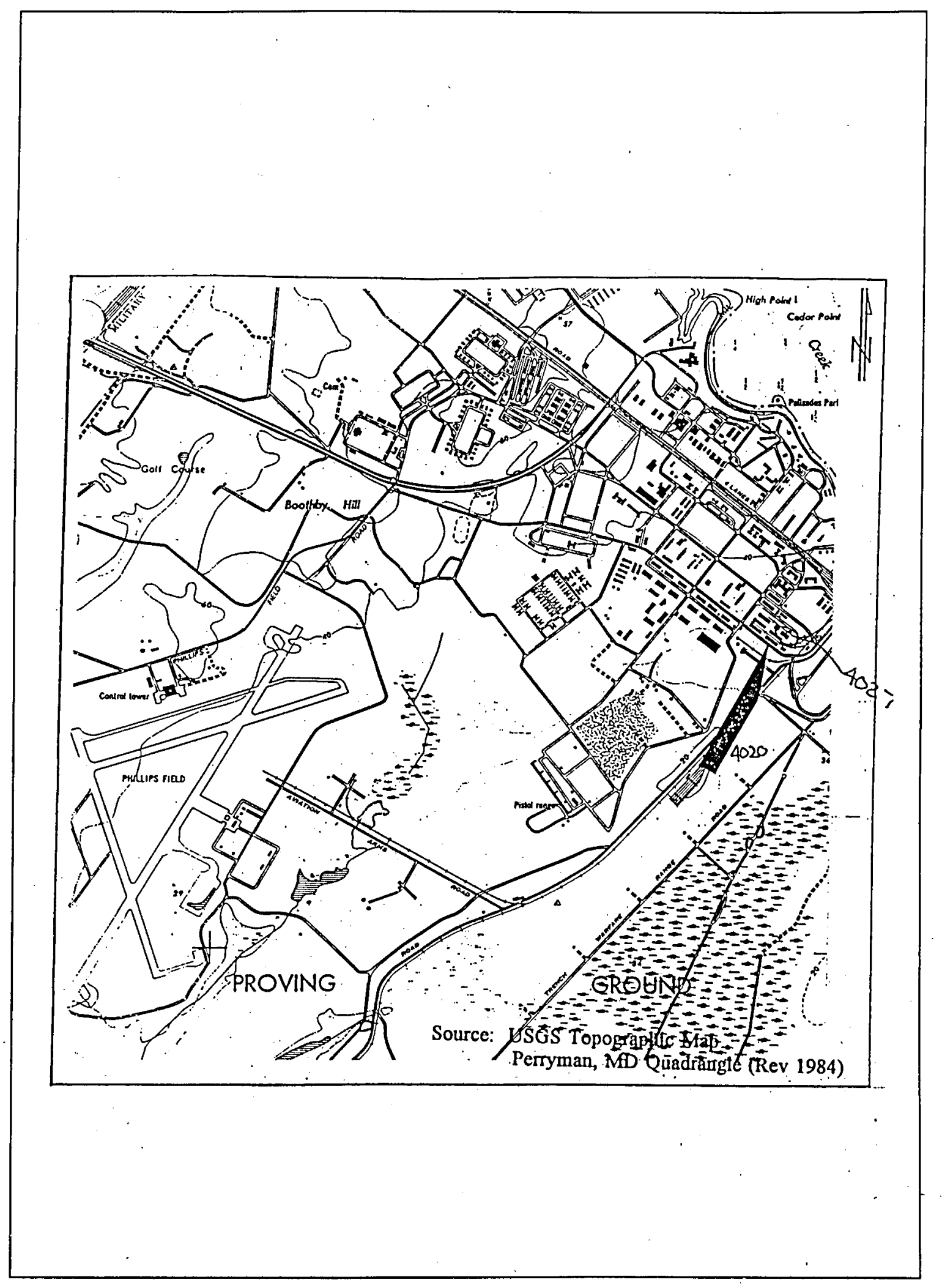

Figure 1. Site map showing Building 4020 within APG 


\section{Site Description}

The SCAPS APG field investigation site is shown in Figure 2. The scope of the investigation initially focused on the area adjacent to Building 4020 and was expanded as the investigation progressed. Previous site investigations have been performed, monitoring wells have been placed, and remediation activities have been accomplished at this site (ENSAT Corporation 1992a,b). The previous investigations identified significant POL contamination near the location of a UST located at the east end of Building 4020.

The site lies approximately $25 \mathrm{ft}$ above mean sea level, and the surface topography does not vary more than $2 \mathrm{ft}$. Subsurface geology consists of unconsolidated sands, gravels, and clays of the Talbot Formation. A layer of silt/clay extends from the surface to approximately $15 \mathrm{ft}$ below surface.

Below $15 \mathrm{ft}$, a layer of predominately coarse-grained soil is approximately 15 to $20 \mathrm{ft}$ thick. This layer contains an unconfined groundwater aquifer. Perched groundwater present at this site is a result of the highly interbedded clay and gravel lenses in the upper silt/clay layer. The general groundwater flow direction is to the northeast as determined from monitoring well logs.

Three monitoring wells have been used as product recovery systems at this site. The monitoring well labeled MW-1, located between Buildings 4040 and 4027 , was pumped to recover fuel product into a 550-gal storage tank (ENSAT Corporation 1992a). Another well labeled MW-1, located just south of the southeast corner of Building 4020, was also pumped to recover fuel product into a 550-gal storage tank (ENSAT Corporation 1992b). It should be noted that Figure 2 includes two wells labeled MW-1; they were installed and labeled separately during two previous investigations. Those two recovery systems were later removed on the assumption that the free POL product had been completely recovered. However, a recovery system is presently operating at MW-11 located between Buildings 4024 and 4025.

The areas around Buildings 4020, 4022, 4024, 4027, and 4040 were chosen for the SCAPS investigation because the area had previously known POL contamination. The reappearance of free product in MW-1 near Building 4020 warranted reassessment of the source of the contamination. The SCAPS investigation was expanded to include the areas around Buildings 4031 and 4035 when SCAPS penetration $\# 32$ detected significant POL contamination. There was no previous knowledge of POL contamination in those areas: 


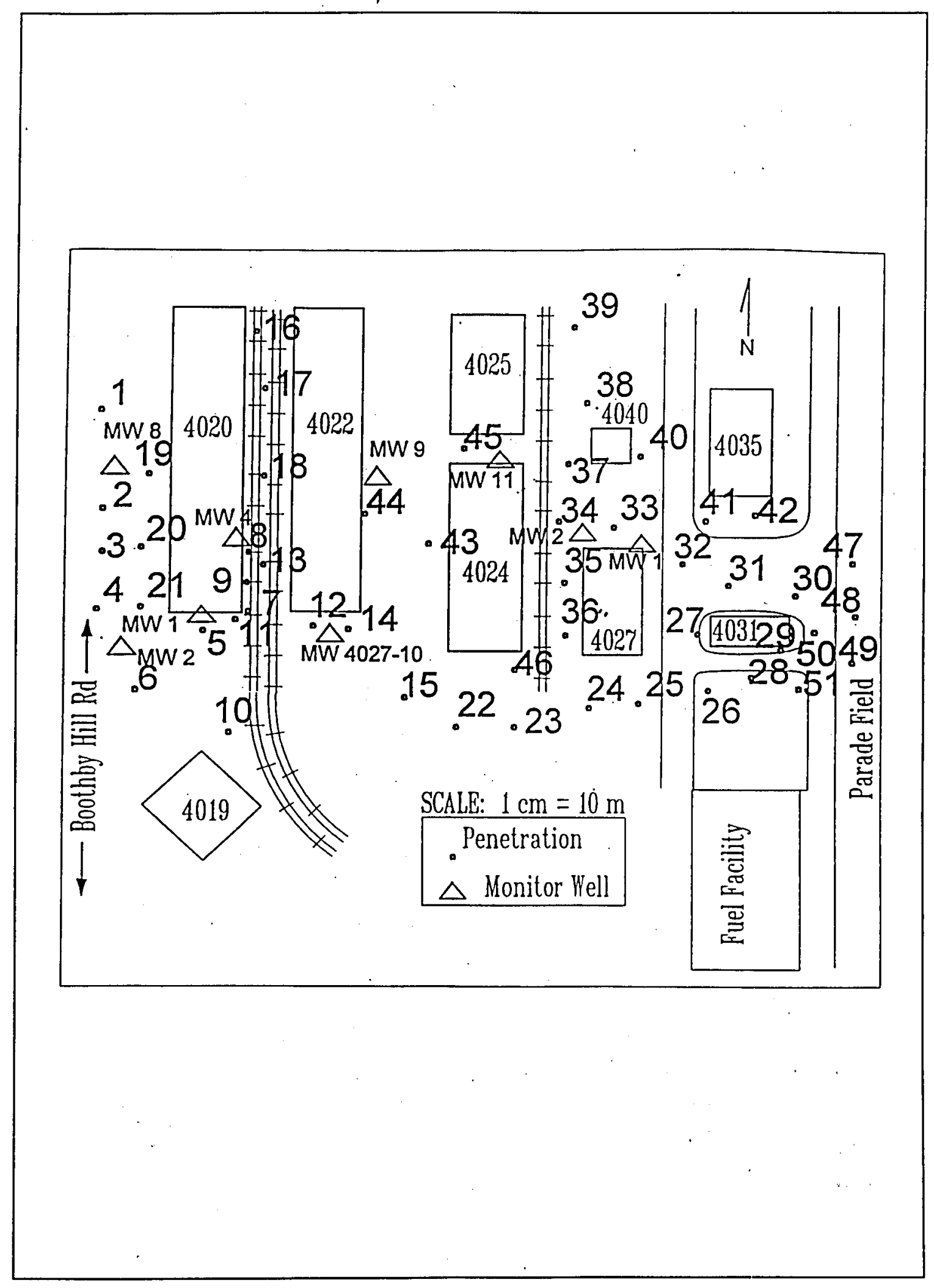

Figure 2. SCAPS investigation site near Building 4020 


\section{Investigation Equipment and Procedures}

\section{General Operations}

SCAPS consists of the cone penetrometer truck, enclosed support trailer containing the decontamination wash water system and grout pumping system, and a mobile analytical laboratory van. Figure 3 shows the SCAPS vehicle and support trailer. The SCAPS sensors used at APG were the soil classification sensor and the laser-induced fluorescence (LIF) sensor combined to form the POL sensor. It should be noted that the soil classification sensor used in the SCAPS is operated in accordance with procedures described in American Society for Testing and Materials (ASTM) Method D3441 (ASTM 1995). For more details, the reader is referred to previous descriptions (Olson and Farr 1986; Lee et al. 1993).

A digging clearance was obtained prior to performing any penetrations in order to comply with APG regulations and the SCAPS APG Safety Plan. The soil classification sensor consists of strain gauges mounted in the penetrometer cone tip and sleeve. These gauges are calibrated at the beginning of each investigation and checked periodically. The LIF sensor is calibrated using an aqueous solution of Rhodamine before and after each penetration event to monitor LIF system response and document any system drift. The standard operating procedures for the SCAPS POL sensor have been described previously (Aptiz et al. 1992; Lee et al. 1994).

Safety precautions involved protection from damage and contamination. Several penetrations required prepushing a few inches to avoid sensor probe damage due to surfaces such as asphalt pavement or gravel. After the measurements for each penetration were completed, the penetration holes were grouted through the probe tip during sensor retraction to prevent cross-strata contamination, and the push rods were decontaminated with the onboard hot water wash (Koester et al. 1993).

Real-time sensor response for the soil classification and LIF sensors is plotted during each penetration. These data allow the operator to observe the soil classification and fluorescence response as the sensors are advanced into 


\section{SITE CHARACTERIZATION AND ANALYSIS PENETROMETER SYSTEM (SCAPS)}

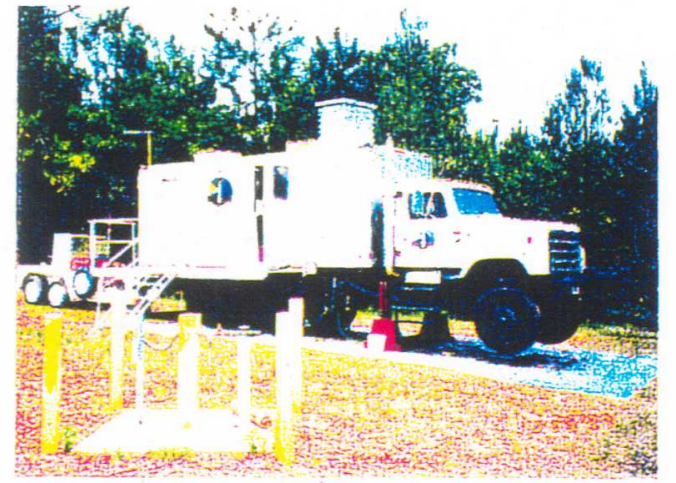

SCAPS Truck and Grout Trailer

(Monitoring Well in Foreground)

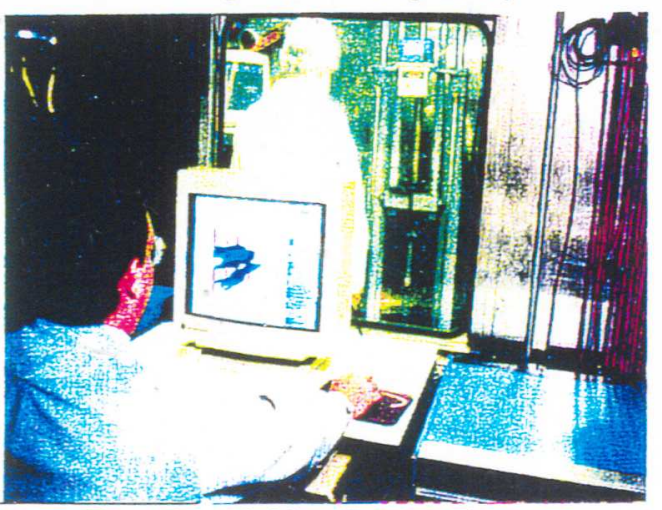

Data Acquisition/Processing Compartment

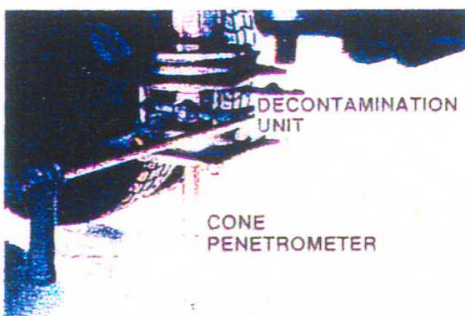

Cone Penetrometer With Sensor Package

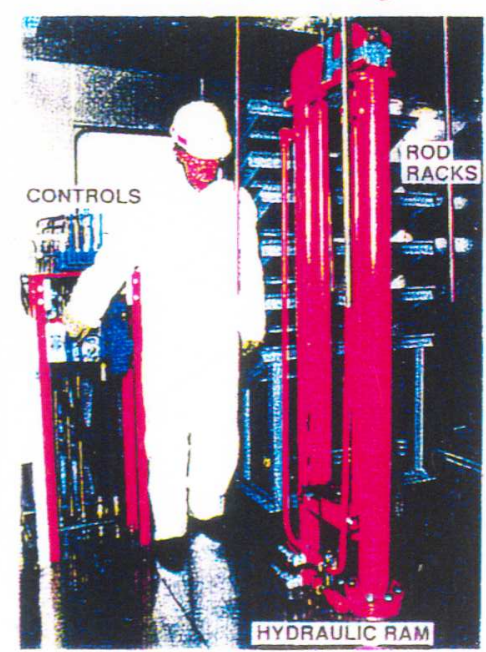

Hydraulic Operations Compartment
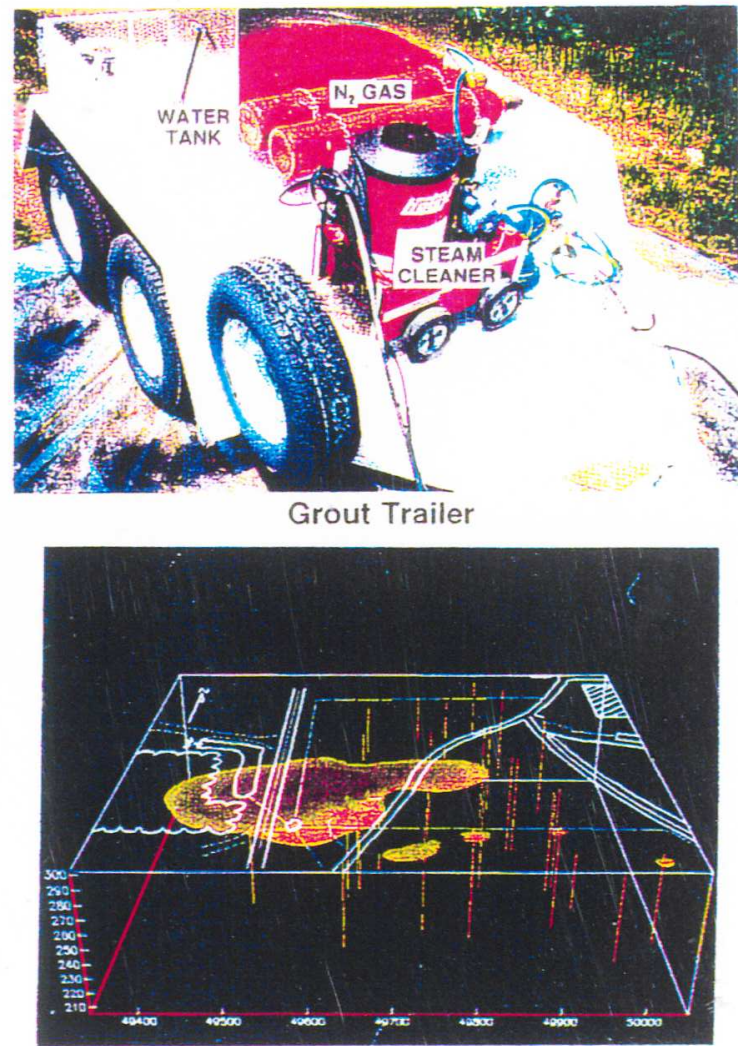

Three-Dimensional Contaminant Visualization

$\checkmark \quad$ Figure 3. The SCAPS system 
<smiles>C1CCCC1</smiles> 
the soil. The sensor data were then plotted as a function of depth for informative visualization (Figure 4).

\section{Penetrometer Fluorescence Verification}

The operating procedures for the SCAPS POL sensor included verification of the fluorescence response for a fraction of the data collected at a particular site. The verification samples were used to confirm the presence of POL contamination detected by the LIF sensor as well as to build a verification database for regulatory acceptance. Soil samples were taken with direct push soil samplers advanced to the sampling depth using the SCAPS truck. Soil samples were obtained at depths of interest approximately $1 \mathrm{ft}$ horizontally offset from corresponding sensor penetrations.

The verification samples were homogenized in the field by mixing with a stainless steel spatula in a stainless steel pan. The samples were placed in precleaned $250-$ or $500-\mathrm{mL}$ glass jars with Teflon-lined caps and stored at $4{ }^{\circ} \mathrm{C}$ until analyzed. The SCAPS LIF response was obtained for each homogenized soil sample in the field by pressing the soil against the sapphire window of the SCAPS POL sensor probe and collecting spectra (Lee et al. 1994). The procedure was carried out in triplicate for each soil sample investigated. Soil analyses for total recoverable petroleum hydrocarbons (TRPH) were performed onsite using a field portable method (Davis, Jones, and Porter 1995) and in the WES analytical laboratory using U.S. Environmental Protection Agency (EPA) Method 418.1 (EPA 1984). Verification samples were also analyzed for polynuclear aromatic hydrocarbons (PAHs) by EPA Method 8270 . 


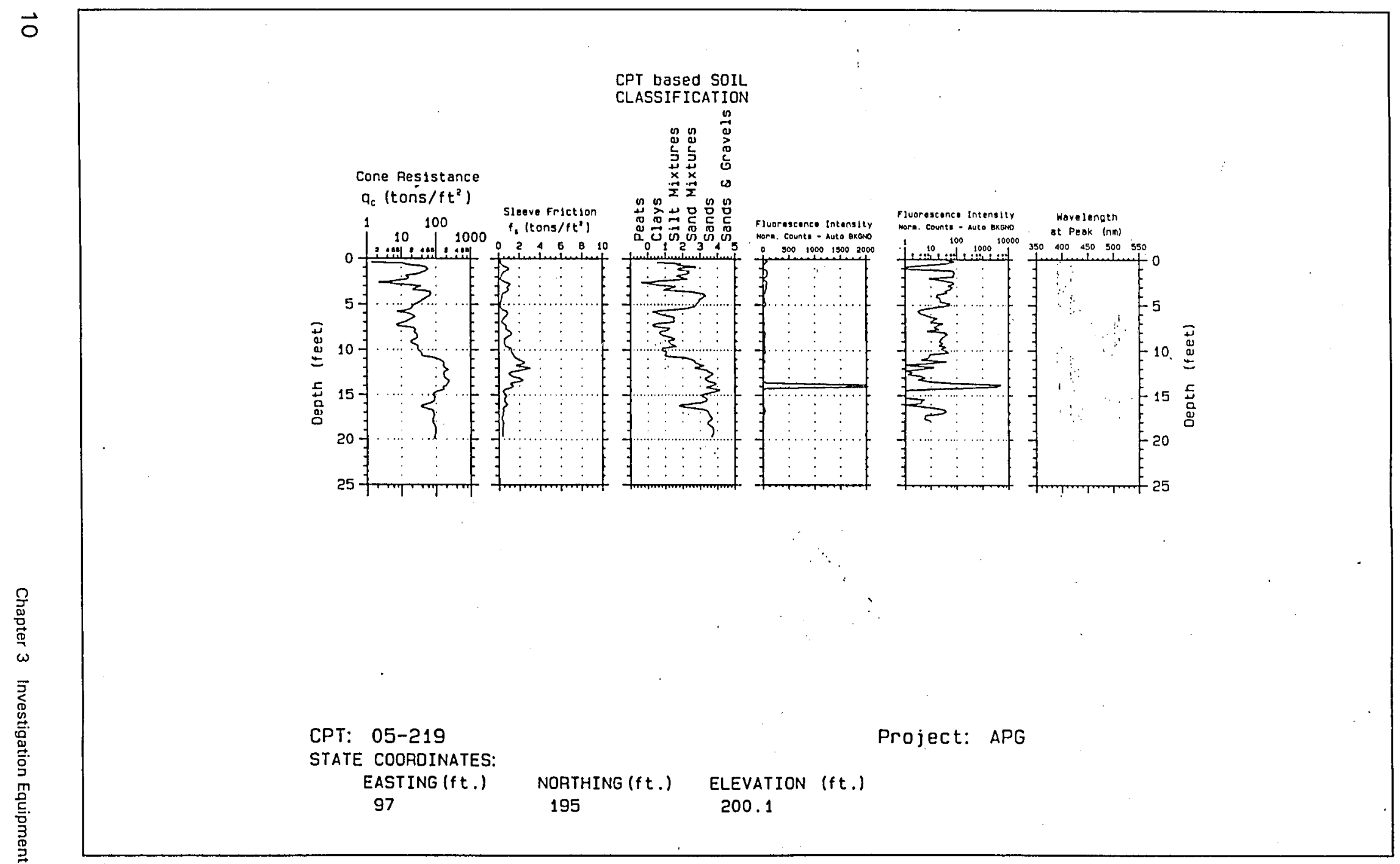

Figure 4. Typical SCAPS panel plot (from penetration \#5 near Building 4020) 


\section{Results and Discussion}

A total of 51 POL sensor penetrations were completed over 12 days. During the same time period, 10 soil sampling penetrations were completed, with 20 verification soil samples retrieved. Three-dimensional (3-D) computer models of both the soil stratigraphy and POL sensor response were generated during the final 3 days of data collection, enabling onsite 3-D visualizations of subsurface site conditions (Figures 5, 6, and 7). The data for Figure 7 are the same as for Figure 6, but replotted to enhance the high-intensity areas.

\section{Soil Classification Measurements}

The site soils consist of gravels, sands, clays, and silts, all highly interbedded. The soil classification sensor data agreed with the soil classification and lithology determined previously (ENSAT Corporation 1992a,b). In general, the fine-grained material to a depth of $15 \mathrm{ft}$ below ground surface (BGS) was underlain by coarse-grained material approximately 15 to $20 \mathrm{ft}$ thick. Below that was another fine-grained material, which appears to be an aquitard based on visual identification of soil sample moisture content. The top of that fine-grained layer (approximately 35 to $38 \mathrm{ft}$ BGS) contains partially decomposed woody material (tree stems) that was not water saturated. The woody material was initially noticed from the amplified LIF response as the probe penetrated the material and was confirmed with subsequent verification soil sampling analyses.

The soil classifications assigned using the SCAPS sensor are those designated in ASTM Method D3441. The soil classification data were plotted as a function of depth and used to generate a 3-D computer model of the site stratigraphy. The site stratigraphy generally conformed to the soil classification and lithology determined from the previous soil borings. However, it should be noted that the SCAPS soil classification sensor stored a data point for every $4 \mathrm{~cm}$ the sensor advanced. The high density of data points for each SCAPS push and the large number of penetrations achievable (e.g., six per day) provide much higher resolution stratigraphic mapping than conventional soil boring techniques (EPA 1995). 
, 
Aberdeen Proving Ground

Soil Stratigraphy

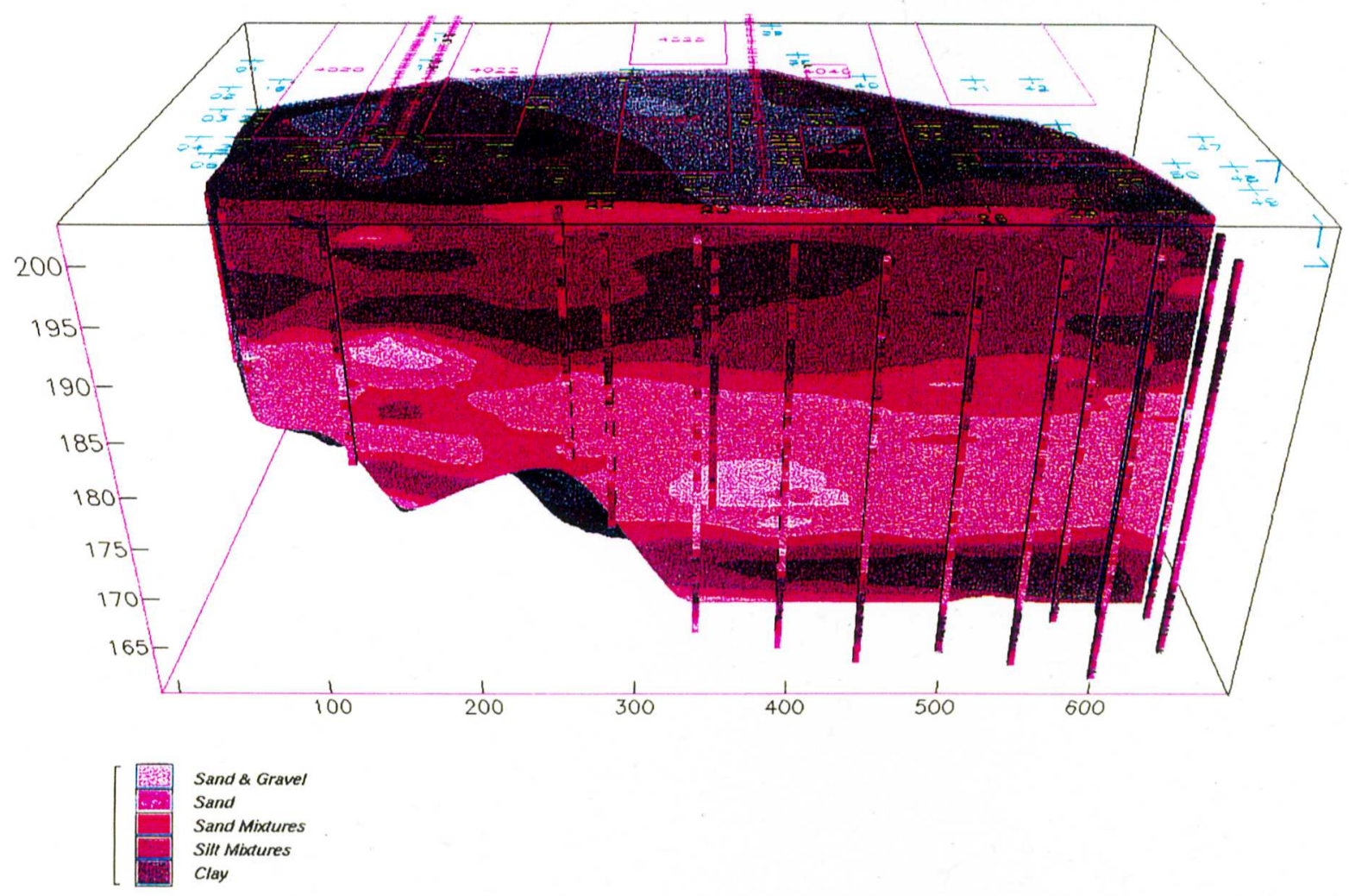





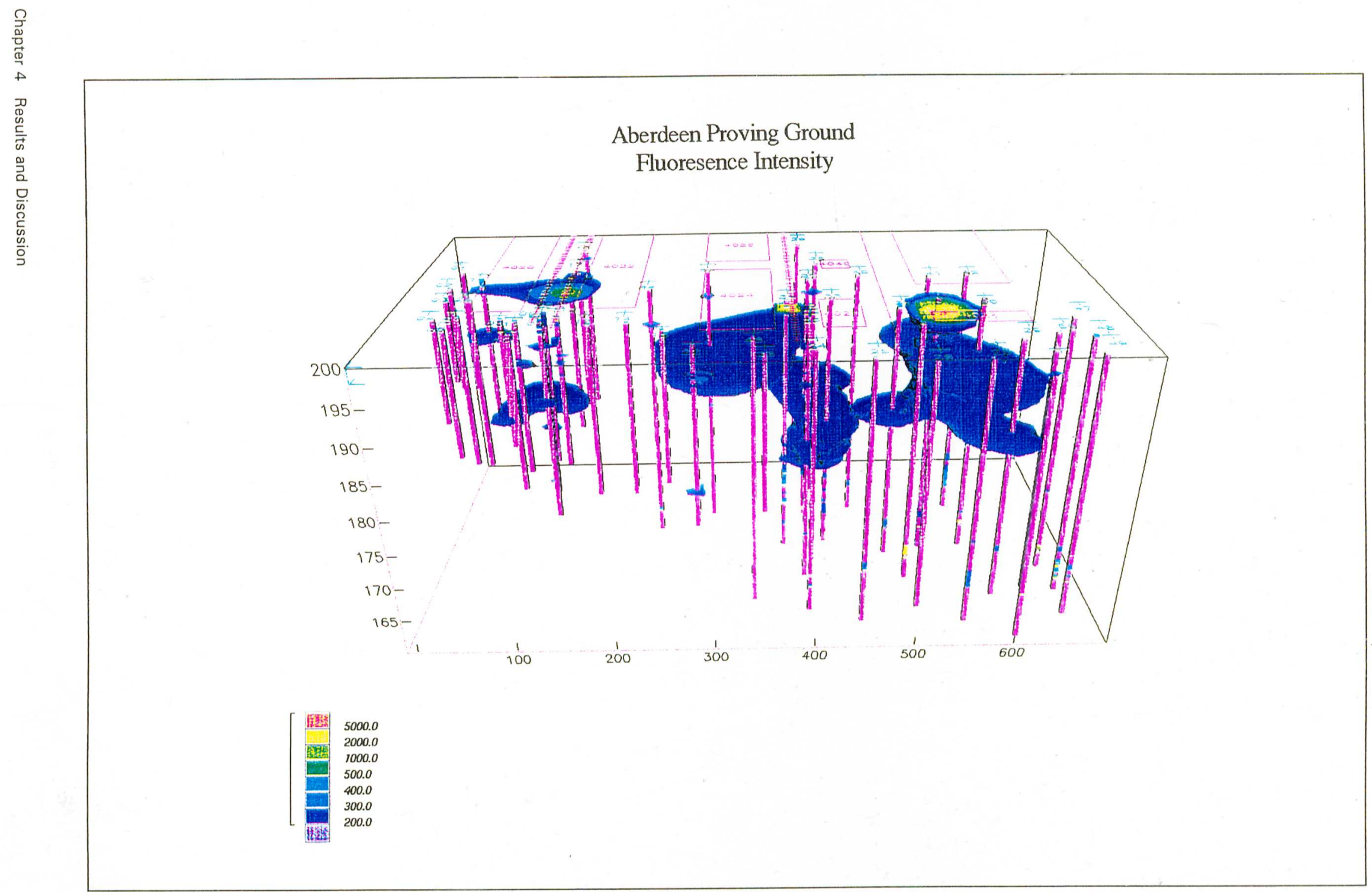

Figure 6. View of SCAPS POL sensor response, low intensity 



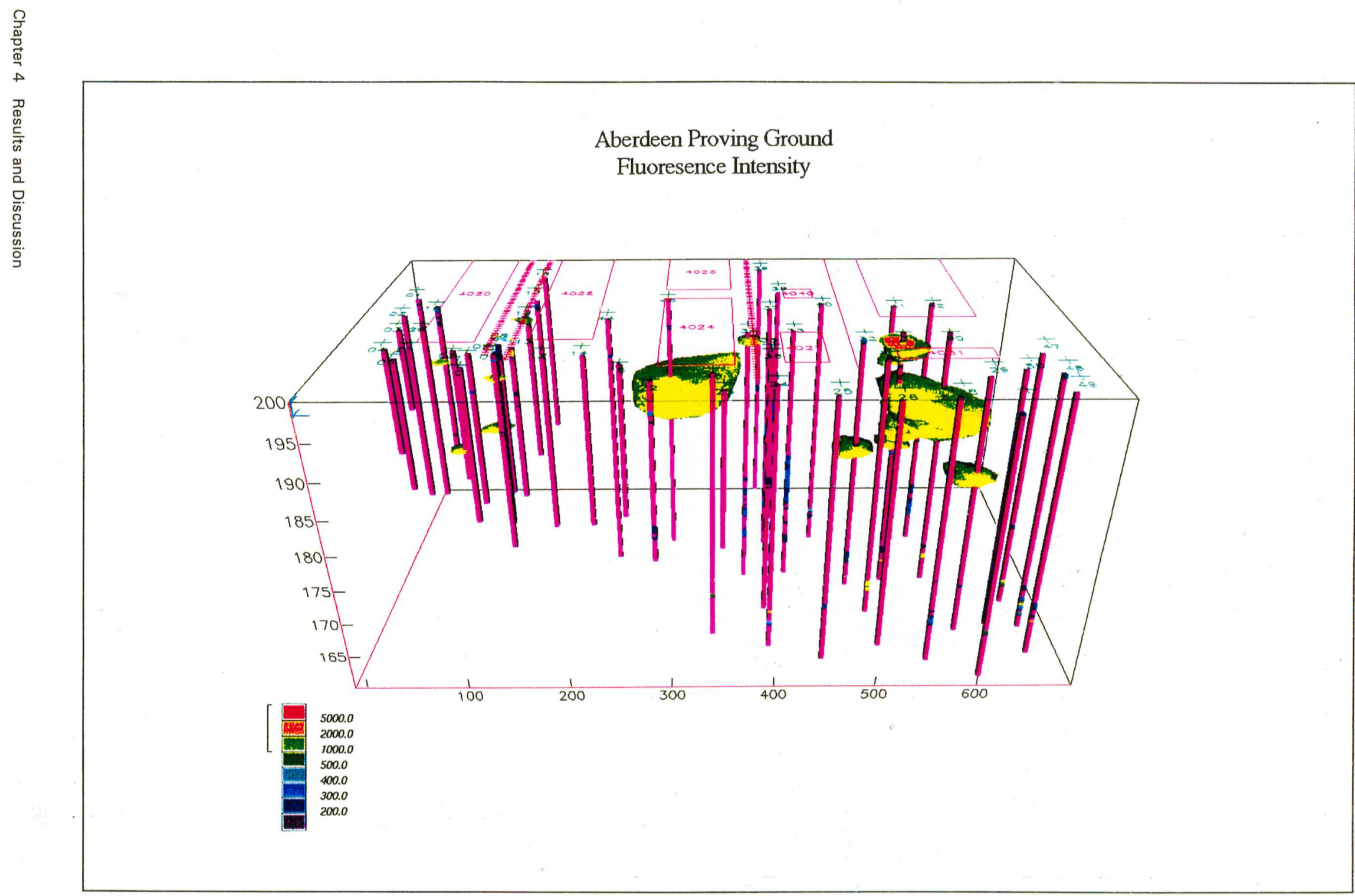

Figure 7. View of SCAPS POL response, high intensity 



\section{Subsurface Petroleum Detection Using the SCAPS POL Sensor}

The SCAPS POL sensor was used to obtain subsurface fluorescence data concurrently with the data collected by the soil classification sensor. These data were plotted real-time during each SCAPS penetration push. After completing a SCAPS push, the data were printed and archived (Appendix A). The locations of penetrations at a particular site were based on historical data and on data generated onsite by SCAPS, allowing the site engineer flexibility in locating penetrations to yield the most informative data.

Initial SCAPS investigations at the APG site were concentrated in the area around the south end of Building 4020 because a previous study indicated POL contamination associated with the $\# 2$ heating oil UST located in this area. Previous investigation indicated free product around $\mathrm{MW}-1$, which had been installed at the previously removed UST location. An additional area of POL contamination was identified near MW-8, where elevated organic vapor analysis (OVA) results were noted during well installation (ENSAT Corporation 1992b).

SCAPS penetrations in the areas around MW-1, MW-4, and MW-8 confirmed the previous findings (Appendix A, Figures A5, A8, and A19). SCAPS penetration \#5 detected a narrow band of intense fluorescence response approximately $14 \mathrm{ft}$ BGS, consistent with the previously reported free product detected in MW-1. Bands of less intense but significant fluorescence response was detected by penetration $\# 19$ (adjacent to MW-8). The SCAPS data indicated low level fluorescence from the surface to $5 \mathrm{ft}$ BGS, and contamination appeared again at $7.5 \mathrm{ft}$ BGS and continued to approximately $20 \mathrm{ft}$ BGS. The OVA analyses performed during the installation of MW-8 indicated elevated readings from 4 to $21 \mathrm{ft}$ BGS.

Slightly elevated OVA response was noted near the surface during installation of MW-4 (ENSAT Corporation 1992b). Fluorescence response detected by the SCAPS POL sensors in this area also indicated low level POL contamination near the surface. SCAPS penetration $\# 8$ (closest to MW-4) detected elevated fluorescence from 0.5 to $3 \mathrm{ft}$ BGS. It should be noted that all the penetrations along the railroad siding between Buildings 4020 and 4022 indicated low fluorescence response near the surface (Appendix A, Figures A7, A9, A13, A16, and A17). The detection of POL contaminants near the surface, all along the railroad siding may indicate fuel leaking from train engines or leached creosote from crossties as possible sources in this area.

Another area investigated was near Buildings 4024, 4025, and 4027. A previous study of the area north of Building 4027 had indicated free product POL contamination, undoubtedly due to the previously removed $\# 2$ heating oil UST (ENSAT Corporation 1992a). A recovery well was installed at MW-1 and the product was recovered. Subsequent soil borings and monitoring wells confirmed that the migration of contaminants was very limited (ENSAT 
Corporation 1992a). The SCAPS POL sensor penetrations in the area indicated very low or nondetectable POL contamination (Appendix A, Figure A33). However, penetration \#45 (near MW-11) on the north end of Building 4024 detected extremely high level POL contamination from 12 to $17 \mathrm{ft}$ BGS (Appendix A, Figure A45). These data are consistent with previous investigations that identified free product in this area.

The third area investigated was east of Building 4027, south of Building 4035 , and all around Building 4031. That area was investigated because significant fluorescence response was noted during SCAPS penetration \#30 (Appendix A, Figure A30). The data indicated a very intense band of POL contamination from 10 to $15 \mathrm{ft}$ BGS. Penetration \#30 was performed to investigate the possible down-gradient migration of free product from the UST that had been located north of Building 4027. However, the low levels of contamination detected in the areas investigated around building 4027 and high contaminant levels detected in penetration \#30 suggested an alternate source of contamination.

Based on the results of penetration $\# 30$, the area of the parking lot to the north of Building 4031 was investigated. The suspected source appears to be in the vicinity of SCAPS penetration \#31 (just west of penetration \#30). That penetration revealed high fluorescence from the surface down to about $15 \mathrm{ft}$ BGS (Appendix A, Figure A31). Subsequent penetrations around Building 4031 delineated the extent of POL contamination in the area (visualized in Figure 5). Penetration \#29 was located to the south of Building 4031 and detected significant fluorescence response in a sandy layer from 13 to $14 \mathrm{ft}$ BGS. Similar levels of contamination were also detected northwest of the building in a sandy layer 15 to $17 \mathrm{ft}$ BGS during penetration \#32 (Appen$\operatorname{dix}$ A, Figure A32).

The other penetrations performed around Building 4031 detected no significant fluorescence response, indicating a lack of POL contamination (Appendix A, Figures A26, A27, A28, A42, A47, A48, A49, A50, and A51). The contamination around Building 4031 thus appears to be relatively localized, as was the case for the leaking USTs at Buildings 4020 and 4027 (ENSAT Corporation 1992a,b). It should be noted that the contamination detected in penetrations $\# 30$ and $\# 31$ was in soil strata that consisted of silts and clays, while the contamination detected in penetrations $\# 29$ and $\# 32$ appear at the top of the sand layer, just below the clay/sand interface. These results indicate that the localized contamination near penetration \#31 has barely seeped onto the groundwater of the surficial aquifer. Data from the SCAPS penetrations performed to the east of Building 4031 (Figure 2, and Appendix A, Figures A47, A48, A49, and A50) indicate that the contamination has not migrated across the street into the parade grounds.

It should be noted that 14 SCAPS penetrations were performed in 2.5 working days and totally delineated the extent of the POL plume in the vicinity of Building 4031. The investigation in the vicinity of Building 4031 completed the SCAPS POL sensor investigation at the APG site. A total of 
51 sensor penetrations were performed during a period of 12 days. Three different areas of POL contamination were investigated during this time.

\section{POL Sensor Verification}

In addition to the SCAPS POL sensor penetrations, 10 penetrations were performed with direct push soil sampling tools to obtain 20 samples for POL sensor verification. Standard verification soil sampling procedures were followed (Koester et al. 1993; Lee et al. 1994). The samples were analyzed onsite for TRPH and offsite at the WES, analytical laboratory for TRPH and PAH. The soil samples were also analyzed for fluorescence response by pressing the soil against the probe window and collecting the fluorescence emission.

Verification soil samples were collected at locations 0.5 to $1 \mathrm{ft}$ horizontally offset from selected sensor penetrations. Soil samples were obtained at depths with high, medium, low, and no fluorescence response (Table 1). Soil samples were named according to the POL sensor penetration being verified (e.g., soil sample 29S1 was the first soil sample obtained adjacent to POL sensor . penetration \#29).

The results show strong correlations between the fluorescence response of the samples, the TRPH (Figure 8), and the total PAH minus naphthalenes (NAPH) (Figure 9). The POL sensor response results from fluorescence emission of the PAH components heavier than naphthalene present in petroleum products (Aptiz et al. 1992). Therefore, it is expected that the strongest correlation would be between the PAH components heavier than naphthalene. For a particular petroleum product, there is a correlation between the TRPH for that product and the PAH concentration (Lee et al. 1994; Davis, Jones, and Porter 1995). Thus, a site contaminated with a single POL product should exhibit a correlation between the TRPH and the POL sensor response.

The influence of the heavier PAHs can be seen in the results of the validation samples collected during the investigation at the APG site (Table 2). The results indicated that the strongest correlation between POL sensor fluorescence response and other POL measures was observed for the total PAH minus NAPH $\left(r^{2}=0.92\right)$. The correlation between the total PAH (including NAPH) and POL sensor response is much weaker $\left(r^{2}=0.79\right)$ and is even weaker for NAPH alone $\left(r^{2}=0.69\right)$. The correlations between both TRPH measures and the POL sensor response were strong $\left(r^{2}=0.91\right.$ for EPA Method $418.1, r^{2}=0.89$ for field portable method, Table 2 ). There is a very strong correlation between the EPA Method 418.1 and the field portable method TRPH $\left(r^{2}=0.99\right)$ (Davis, Jones, and Porter 1995).

Soil samples were also obtained to verify apparently anomalous POL sensor responses. Non-POL fluorescence has been documented to occur due to the presence of fluorescent minerals (Lee et al. 1994). Soil samples were obtained at all locations that yielded POL sensor fluorescence response in a 


\begin{tabular}{|c|c|c|c|c|c|c|c|}
\hline \multicolumn{8}{|c|}{$\begin{array}{l}\text { Table } 1 \\
\text { APG Validation Sample Results }\end{array}$} \\
\hline $\begin{array}{l}\text { Sample } \\
\text { Name }\end{array}$ & $\begin{array}{l}\text { Sampling } \\
\text { Depth BGS } \\
\mathrm{ft}\end{array}$ & $\begin{array}{l}\text { POL Sensor } \\
\text { Response } \\
\text { Counts }\end{array}$ & $\begin{array}{l}\text { TRPH } \\
\text { Field } \\
\text { Method } \\
\mathrm{mg} / \mathrm{kg} \\
\end{array}$ & $\begin{array}{l}\text { EPA } \\
\text { Method } \\
418.1 \\
\mathrm{mg} / \mathrm{kg} \\
\end{array}$ & $\begin{array}{l}\text { Total } \\
\mathrm{PAH} \\
\mathrm{mg} / \mathrm{kg}\end{array}$ & $\begin{array}{l}\text { Total } \\
\text { PAH- } \\
\text { NAPH } \\
\text { mg/kg }\end{array}$ & $\begin{array}{l}\text { Total } \\
\text { NAPH } \\
\mathbf{m g} / \mathbf{k g} \\
\end{array}$ \\
\hline 0552 & $13.5-15.0$ & $5,695.0$ & 7,337 & 7,500 & 31.9 & 15.77 & 16.13 \\
\hline 0551 & $13.6-14.4$ & 104.3 & $<10$ & $<25$ & $<0.41$ & $<0.41$ & $<0.41$ \\
\hline 0951 & $3.83-4.17$ & 145.3 & 16 & $<25$ & $<0.41$ & $<0.41$ & $<0.41$ \\
\hline 1751 & $1.0-1.75$ & 167.3 & $<10$ & $<25$ & 0.56 & 0.52 & 0.04 \\
\hline $17 S 2$ & $4.0-5.0$ & 141.3 & $<10$ & $<25$ & $<0.41$ & $<0.41$ & $<0.41$ \\
\hline 1753 & $6.5-7.5$ & 115.7 & $<10$ & $<25$ & $<0.41$ & $<0.41$ & $<0.41$ \\
\hline $19 S 1$ & $7.5-8.25$ & 136.3 & $<10$ & $<25$ & $<0.41$ & $<0.41$ & $<0.41$ \\
\hline $19 S 2$ & $8.25-9.0$ & 223.0 & 10 & $<25$ & $<0.41$ & $<0.41$ & $<0.41$ \\
\hline 2751 & $32.0-33.5$ & 218.7 & $<10$ & $<25$ & $<0.41$ & $<0.41$ & $<0.41$ \\
\hline 27S2 & $33.5-34.5$ & 137.7 & 11 & 200 & $<0.41$ & $<0.41$ & $<0.41$ \\
\hline 2951 & $13.5-13.8$ & $15,594.0$ & 51,444 & 62,000 & 407.87 & 105.87 & 302.0 \\
\hline $29 S 2$ & $13.8-14.4$ & 2.920 .0 & 5,944 & 7,500 & 49.49 & 14.27 & 35.22 \\
\hline 3151 & $3.5-4.0$ & 357.7 & 152 & 370 & 2.65 & 1.17 & 1.48 \\
\hline $31 \mathrm{~s} 2$ & $4.25-5.0$ & 415.7 & 745 & 2,000 & 15.91 & 5.59 & 10.32 \\
\hline 3153 & $11.5-12.0$ & $5,341.7$ & 4,681 & 8,400 & 55.19 & 20.98 & 34.21 \\
\hline 3851 & $18.0-18.7$ & 171.7 & $<25$ & $<25$ & $<0.41$ & $<0.41$ & $<0.41$ \\
\hline 3852 & $32.75-34$ & 205.0 & $<25$ & $<25$ & $<0.41$ & $<0.41$ & $<0.41$ \\
\hline $45 \mathrm{S1}$ & $13.0-14.0$ & 144.3 & 87 & 66 & 0.089 & 0.089 & $<0.41$ \\
\hline $45 \mathrm{~S} 2$ & $17.0-17.83$ & 194.7 & 598 & 920 & 1.938 & 1.29 & 0.648 \\
\hline 5351 & $32.6-33.4$ & 156.3 & 32 & 52 & 0.435 & 0.215 & 0.22 \\
\hline
\end{tabular}

strata or geologic location where POL contamination would not be expected. For example, there was often significant fluorescence response at 31 to $35 \mathrm{ft}$ BGS (Appendix A, Figures A24, A27, A38, A40, A44, A47, A48, and A51). The fluorescent responses all occurred at a sand/clay interface and were located at depths significantly below the top of the surficial aquifer.

Based on these observations, it was suspected that fluorescence at these locations was not due to POL contamination. Verification soil samples obtained at these locations (Table 1, samples 27S1, 27S2, and 38S2) confirmed the lack of POL contamination at these locations. In addition, samples 27S2 and 39S2 both contained pieces of wood that yielded significant fluorescence response when analyzed. Naturally occurring soil organic matter is 
Figure $8 \mathrm{~A}$

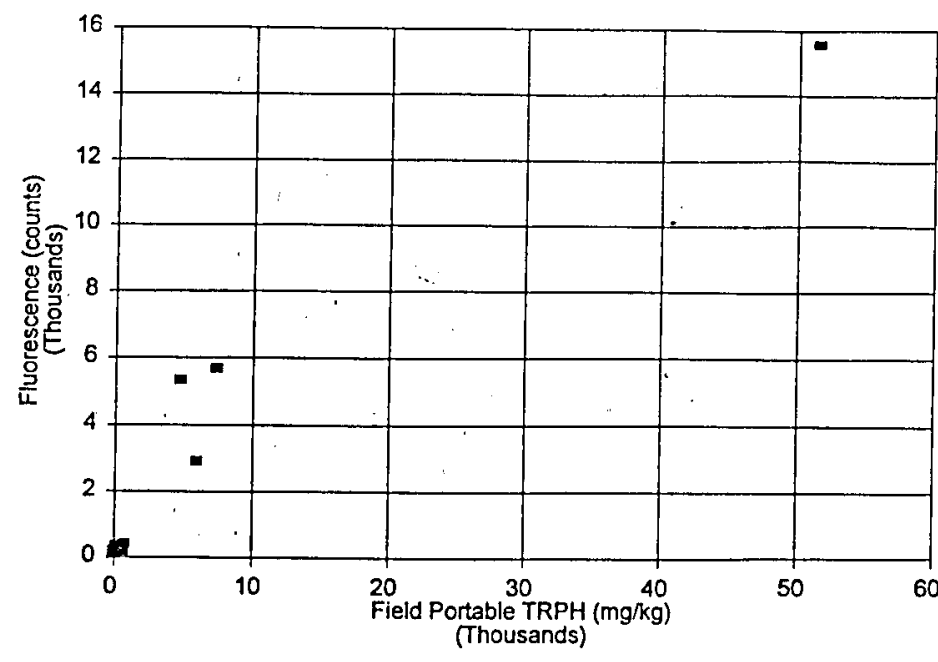

Figure 8B

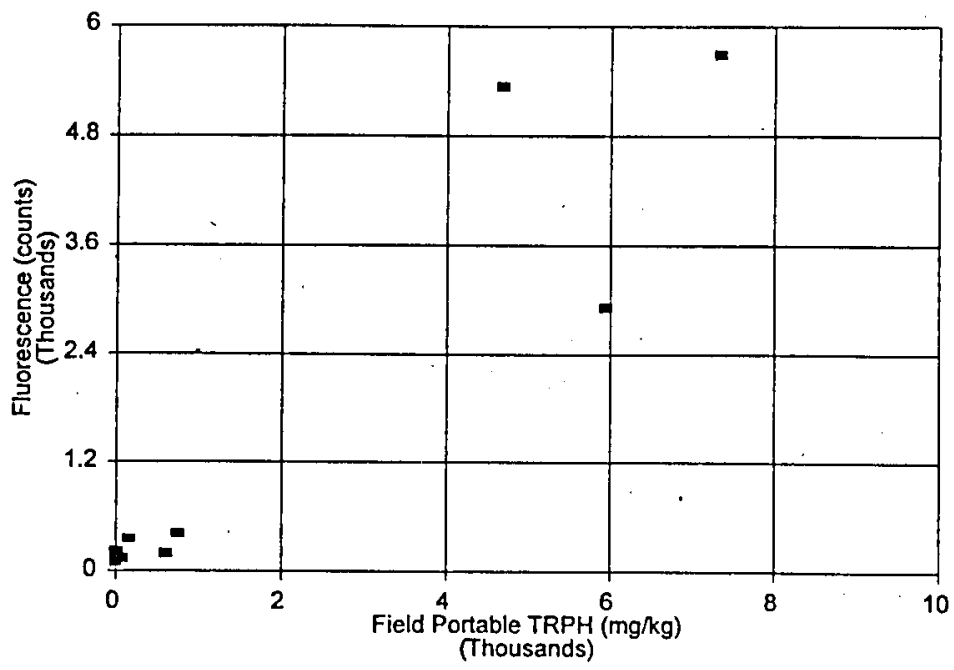

Figure 8. Comparison between TRPH and POL sensor response $18 \mathrm{~A}$ contains all data presented in Table $1 ; 8 \mathrm{~B}$ is an expanded view of the low concentration region of 8A) 


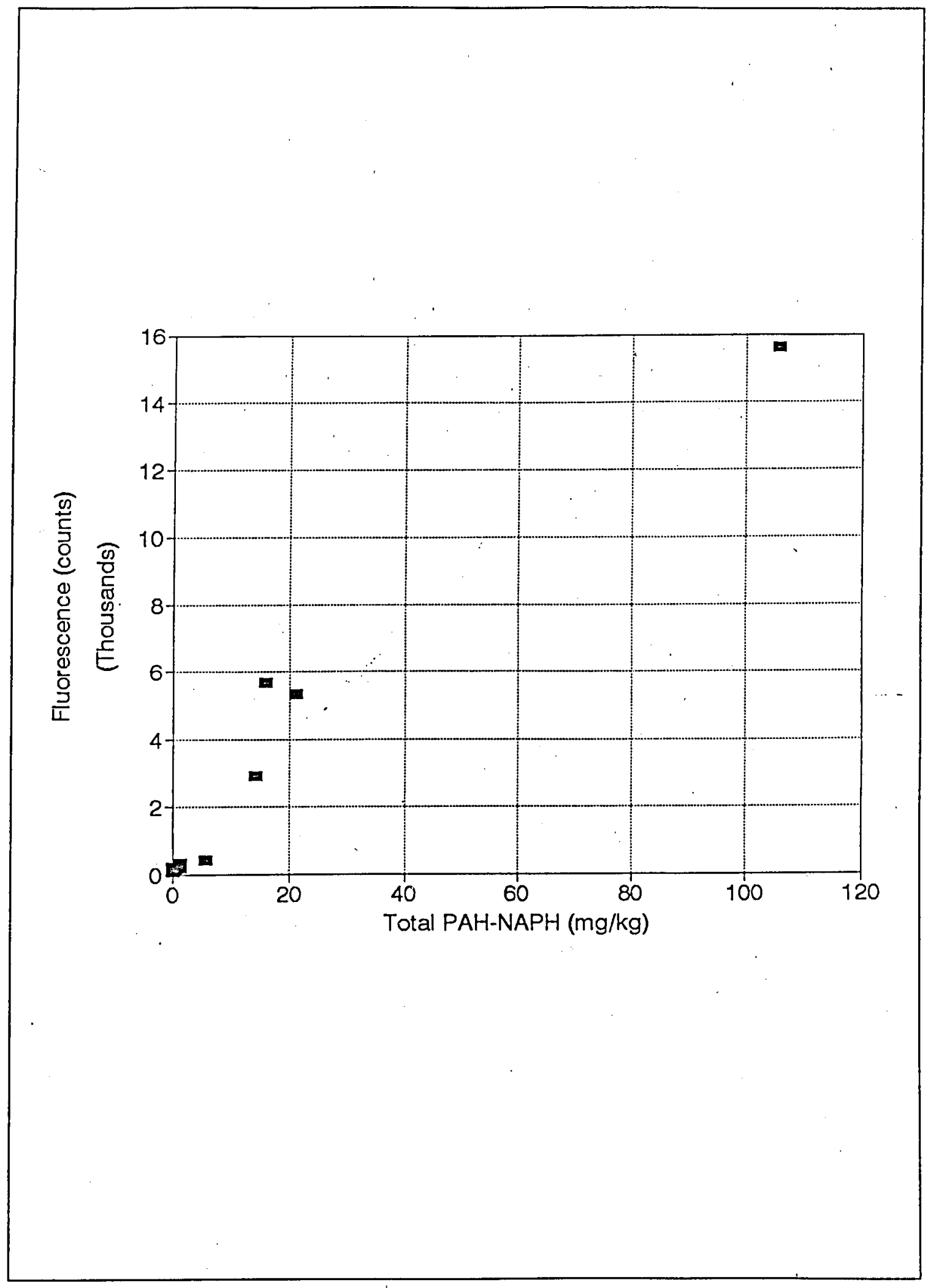

Figure 9. Comparison between PAH-NAPH and POL sensor response 


\begin{tabular}{|c|c|c|c|}
\hline \multicolumn{4}{|c|}{$\begin{array}{l}\text { Table } 2 \\
\text { Aberdeen Proving Grounds Validation Soil Sample Results }\end{array}$} \\
\hline \multicolumn{2}{|c|}{ EPA Method 418.1 Versus POL Sensor Response } & \multicolumn{2}{|c|}{ Total PAH Versus POL Sensor Response } \\
\hline \multicolumn{2}{|c|}{ Regression Output } & \multicolumn{2}{|c|}{ Regression Output } \\
\hline $\begin{array}{l}\text { Constant } \\
\text { Std Err of Y Est } \\
\text { R Squared } \\
\text { No. of Observations } \\
\text { Degrees of Freedom }\end{array}$ & $\begin{array}{l}72.77089 \\
541.1965 \\
0.909438 \\
19 \\
17 \\
\end{array}$ & $\begin{array}{l}\text { Constant } \\
\text { Std Err of } Y \text { Est } \\
\text { R Squared } \\
\text { No. of Observations } \\
\text { Degrees of Freedom }\end{array}$ & $\begin{array}{l}150.9029 \\
820.0173 \\
0.792087 \\
19 \\
17 \\
\end{array}$ \\
\hline $\begin{array}{l}\text { X Coefficient(s) } \\
\text { Std Err of Coef }\end{array}$ & $\begin{array}{l}0.577941 \\
0.044233 \\
\end{array}$ & $\begin{array}{l}X \text { Coefficient(s) } \\
\text { Std Err of Coef }\end{array}$ & $\begin{array}{l}89.30408 \\
11.0969 \\
\end{array}$ \\
\hline \multicolumn{2}{|c|}{ TRPH Field Method Versus POL Sensor Response } & \multicolumn{2}{|c|}{ Total PAH-NAPH Versus POL Sensor Response } \\
\hline \multicolumn{2}{|c|}{ Regression Output } & \multicolumn{2}{|c|}{ Regression Output } \\
\hline $\begin{array}{l}\text { Constant } \\
\text { Std Err of } Y \text { Est } \\
R \text { Squared } \\
\text { No. of Observations } \\
\text { Degrees of Freedom }\end{array}$ & $\begin{array}{l}139.2433 \\
589.4408 \\
0.892572 \\
19 \\
17 \\
\end{array}$ & $\begin{array}{l}\text { Constant } \\
\text { Std Err of Y Est } \\
R \text { Squared } \\
\text { No. of Observations } \\
\text { Degrees of Freedom }\end{array}$ & $\begin{array}{l}69.76189 \\
512.7827 \\
0.918698 \\
19 \\
17 \\
\end{array}$ \\
\hline \multirow[t]{5}{*}{$\begin{array}{l}\text { X Coefficient(s) } \\
\text { Std Err of Coef } \\
\end{array}$} & $\begin{array}{l}0.731322 \\
0.061535\end{array}$ & $\begin{array}{l}\text { X Coefficient(s) } \\
\text { Std Err of Coef }\end{array}$ & $\begin{array}{r}261.5653 \\
18.87212\end{array}$ \\
\hline & & \multicolumn{2}{|c|}{ Total NAPH Versus POL Sensor Response } \\
\hline & & \multicolumn{2}{|c|}{ Regression Output } \\
\hline & & $\begin{array}{l}\text { Constant } \\
\text { Std Err of Y Est } \\
\text { R Squared } \\
\text { No. of Observations. } \\
\text { Degrees of Freedom }\end{array}$ & $\begin{array}{l}223.75179 \\
993.9005 \\
0.694563 \\
19 \\
17\end{array}$ \\
\hline & & $\begin{array}{l}\text { X Coefficient(s) } \\
\text { Std Err of Coef }\end{array}$ & $\begin{array}{r}129.6494 \\
20.85217\end{array}$ \\
\hline
\end{tabular}

known to fluoresce (Christman and Gjessing 1983; Thurman 1985). The fluorescence response at these locations and depths was determined onsite with the TRPH analysis to be due to naturally occurring organic matter. 


\section{Summary and Conclusions}

The SCAPS POL sensor site investigation at Aberdeen Proving Ground demonstrated the rapid site characterization capabilities of SCAPS. The investigation at Buildings 4020,4025 , and 4027 confirmed the presence of previously known POL.contamination. The SCAPS penetrations in these areas confirmed the localized nature of the contamination in these areas.

SCAPS penetrations in the vicinity of Building 4031 identified an area of previously unknown POL contamination. The contamination in this area was also shown to be relatively localized. The ability to locate data collection points (SCAPS POL sensor penetrations) based on data generated onsite in real-time was demonstrated to greatly accelerate the delineation of the POL plume in the vicinity Building 4031. The POL contamination in this area was mapped with 14 SCAPS sensor penetrations, requiring approximately 2.5 working days.

Soil samples obtained for POL sensor verification indicated a strong correlation between conventional methods of POL measurement and the SCAPS POL sensor response. 


\section{References}

Aptiz, S. E., Borbridge, L. M., Theriault, G. A., and Lieberman, S. H. (1992). Analus 20, 461-474.

American Society for Testing and Materials (ASTM). (1995). Annual book of ASTM standards. 04.08 (D-3441), Philadelphia.

Christman, R. F., and Gjessing, E. T. (1983). Aquatic and terrestrial humic materials. Ann Arbor Science Publishers, Ann Arbor. MI.

Davis, W. M., Jones, P., and Porter, B. (1995). "Field portable petroleum analysis for validation of the site characterization and analysis penetrometer system petroleum, oil and lubricant sensor." Proceedings of the fourth international symposium of field screening methods for hazardous waste and toxic chemicals. U.S. Environmental Protection Agency, Las Vegas, NV.

ENSAT Corporation. (1992a). "Site characterization APG-Building 4027 Aberdeen, Maryland ENSAT Job \#91A-00040," Culpeper, VA.

. (1992b). "Site characterization APG-Building 4020 Aberdeen, Maryland ENSAT Job \#91A-00045,” Culpeper, VA.

Koester, J. P., Lee, L. T., Powell, J. F., and Goodson. R. (1993). “Operators manual for the site characterization and analysis penetrometer system," U.S. Army Engineer Waterways Experiment Station. Vicksburg, MS.

Lee, L. T., Chrestman, A. M., Douglas, D. H., Powell, J. F., and Malone, P. G. (1993). "Site investigations with the site characterization and analysis penetrometer system at Fort Dix, New Jersy," Teclnnical Report GL-9317, U.S. Army Engineer Waterways Experiment Station, Vicksburg, MS.

Lee, L. T., Davis, W. M., Goodson, R. A., Powell, J. F., and Register, B. A. (1994). "Site characterization and analysis penetrometer (SCAPS) field investigation at the Sierra Army Depot, California." Technical Report GL-94-4, U.S. Army Engineer Waterways Experiment Station, Vicksburg, MS. 
Olsen, R. S., and Farr, J. V. (1986). "Site characterization using the cone penetrometer test." Proceedings of the American Society of Civil Engineers Conference on in-situ testing in geotechnical engineering: New York.

Thurman; E. M. (1985). Organic geochemistry of natural water. Kluwer Academic Publishers, Hingham, MA.

U.S. Environmental Protection Agency. (1984). "Test methods for evaluating solid waste; Physical/chemical methods," SW-846 Third Edition, Washington, DC.

- (1995). "Tri-Service SCAPS technology innovative technology evaluation report," Office of Research and Development, Washington, DC. 


\section{Appendix A SCAPS POL Sensor Panel Plots}




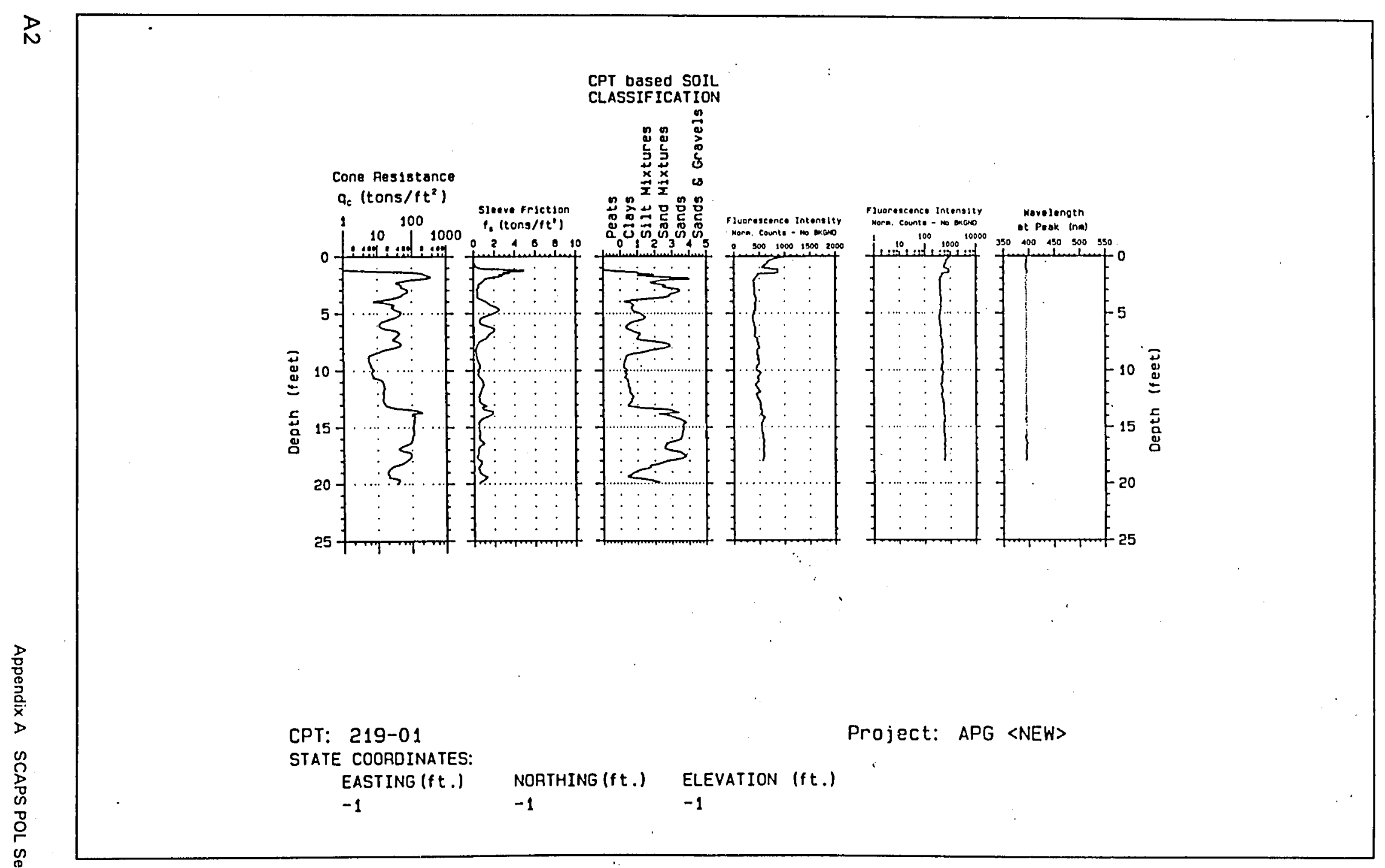

Figure A1. CPT 219-01, Aberdeen Proving Ground 


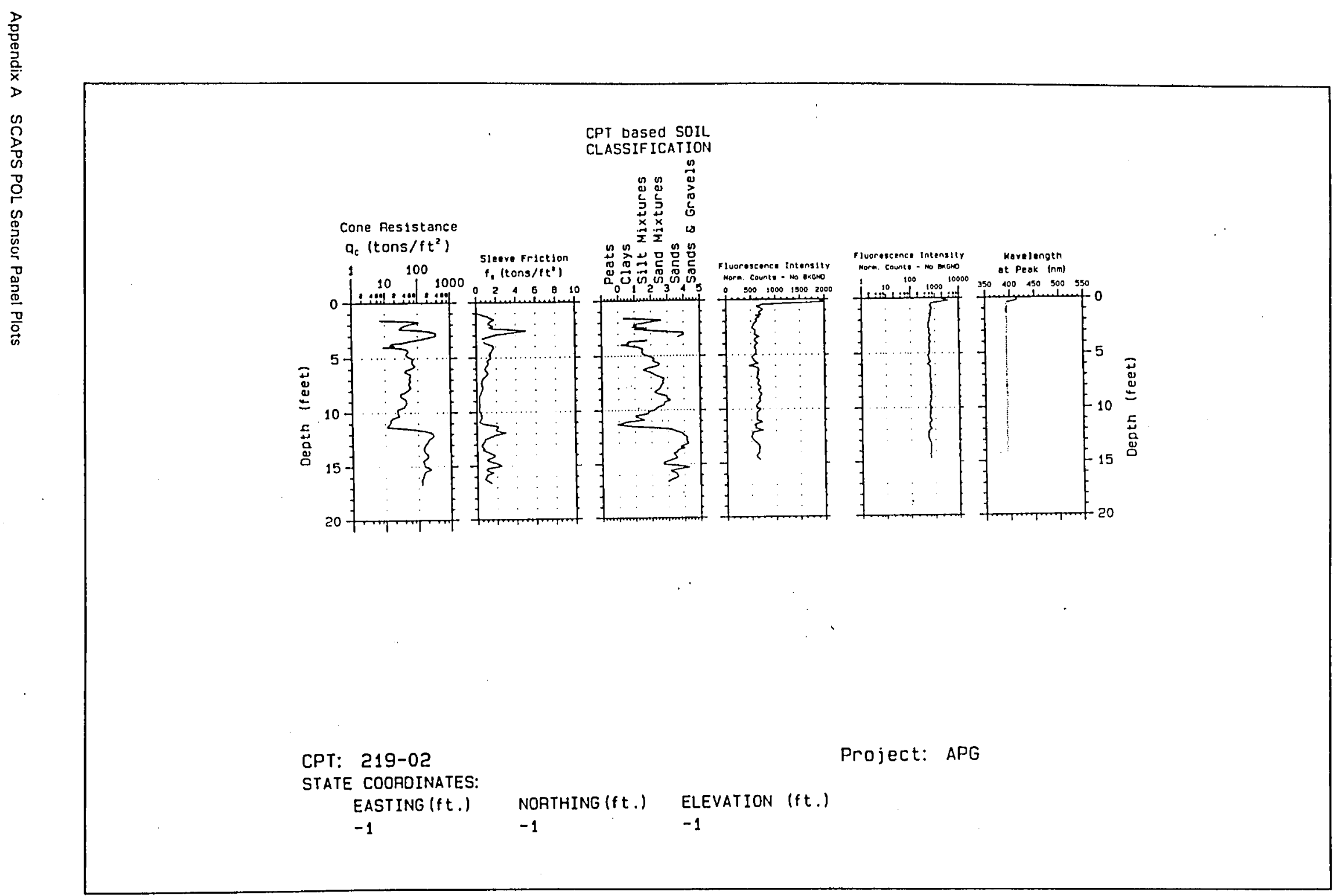




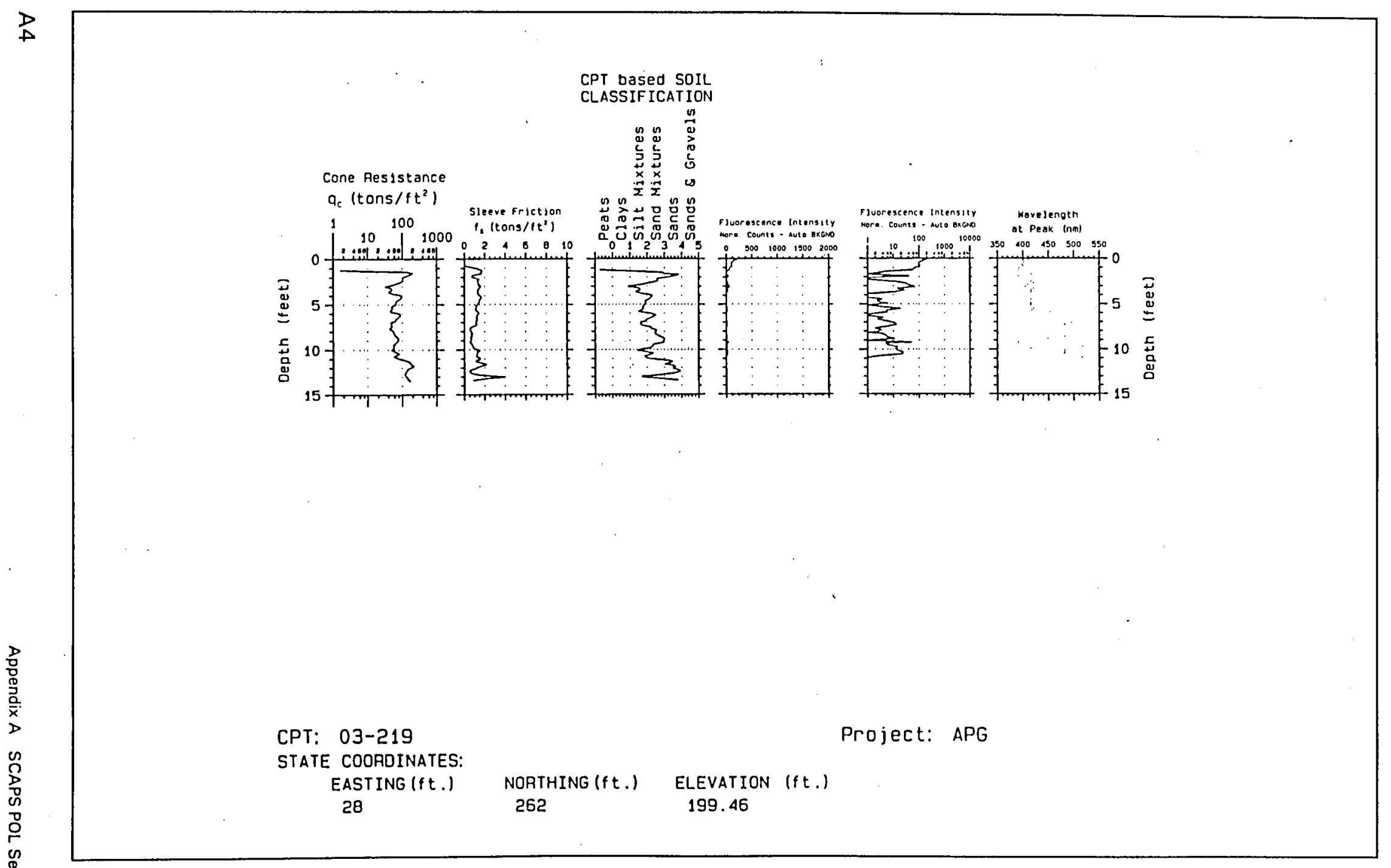

Figure A3. CPT 03-219, Aberdeen Proving Ground 


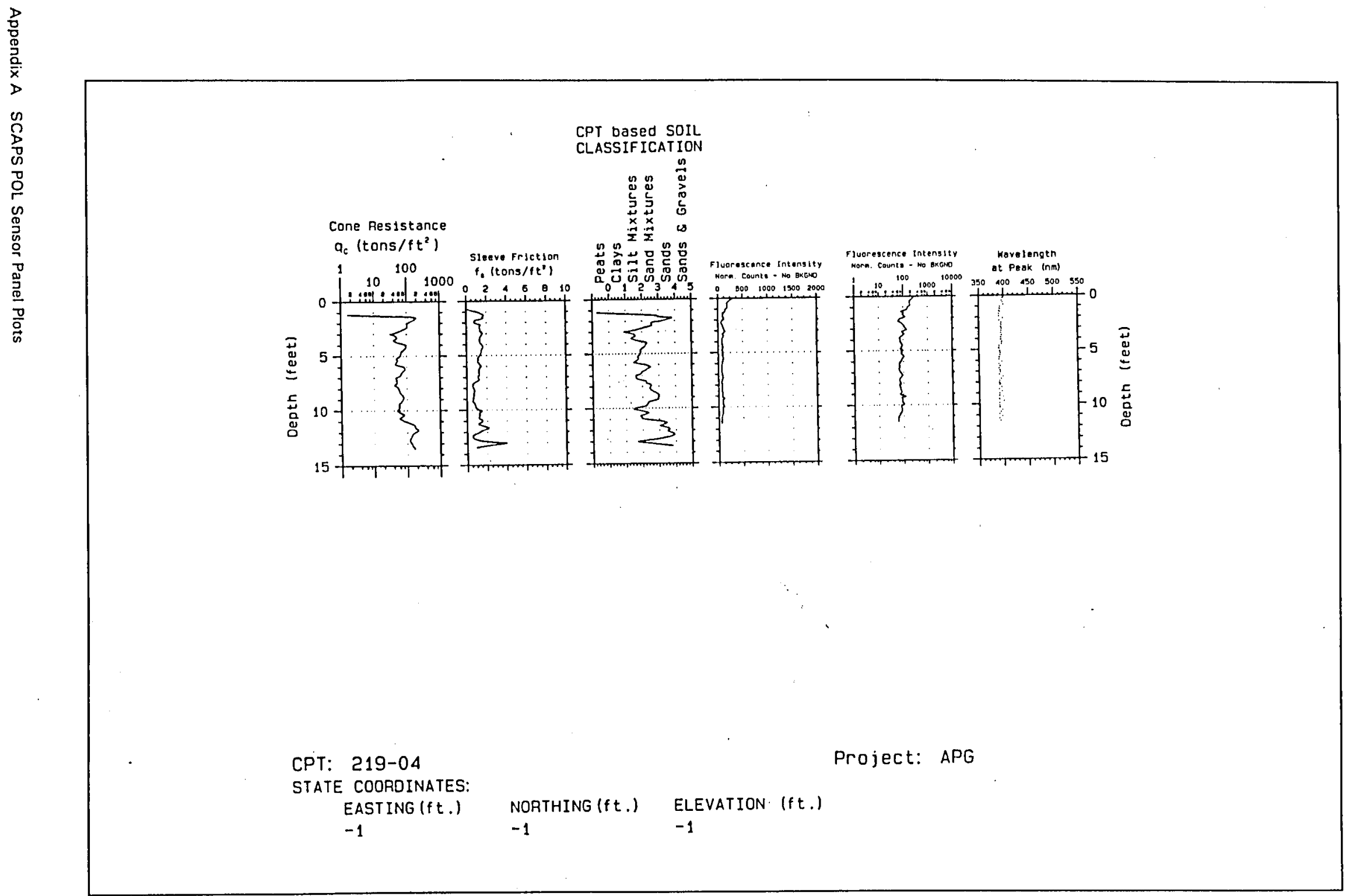

or Figure A4. CPT 04-219, Aberdeen Proving Ground 


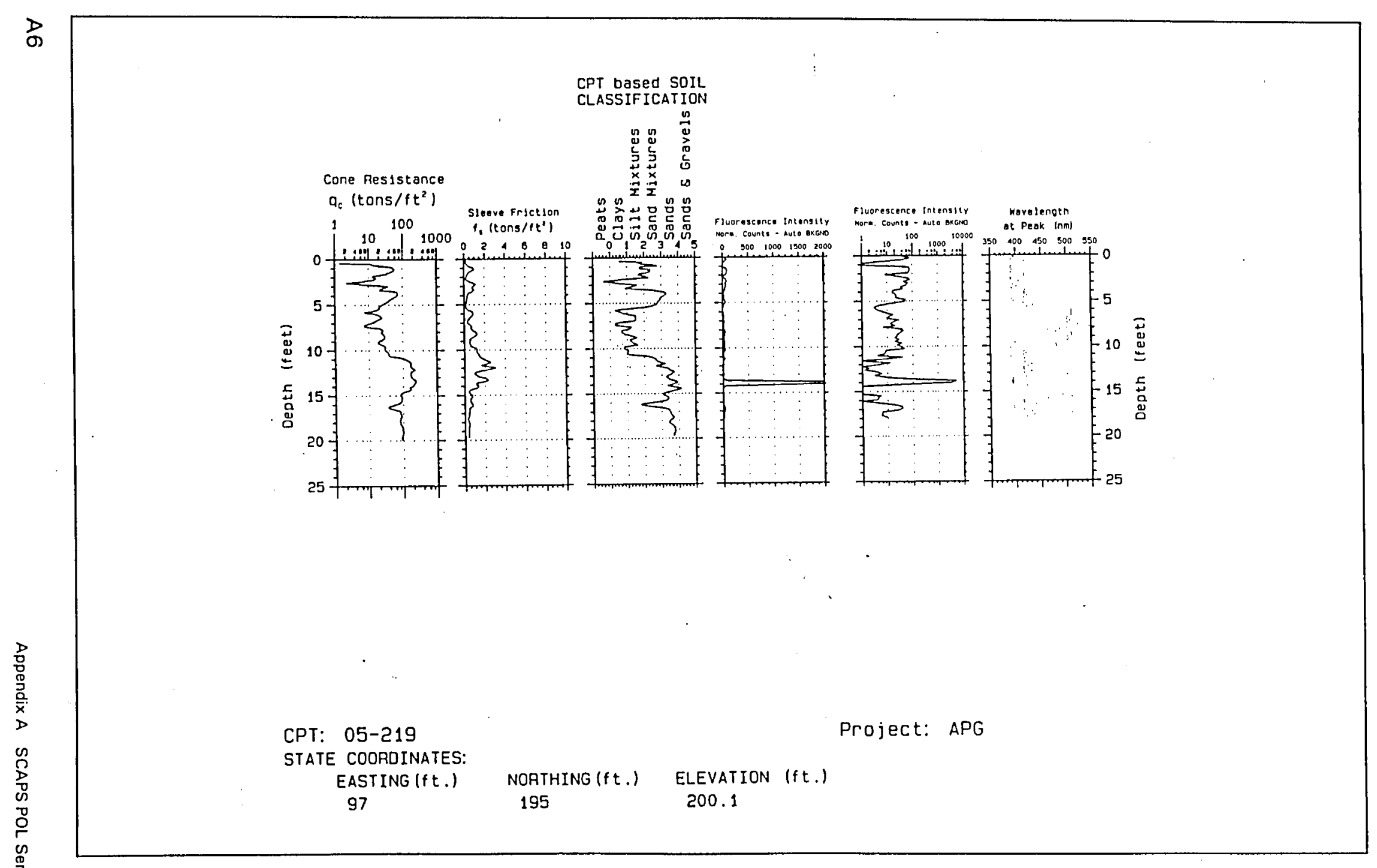

Figure A5. CPT 05-219, Aberdeen Proving Ground 


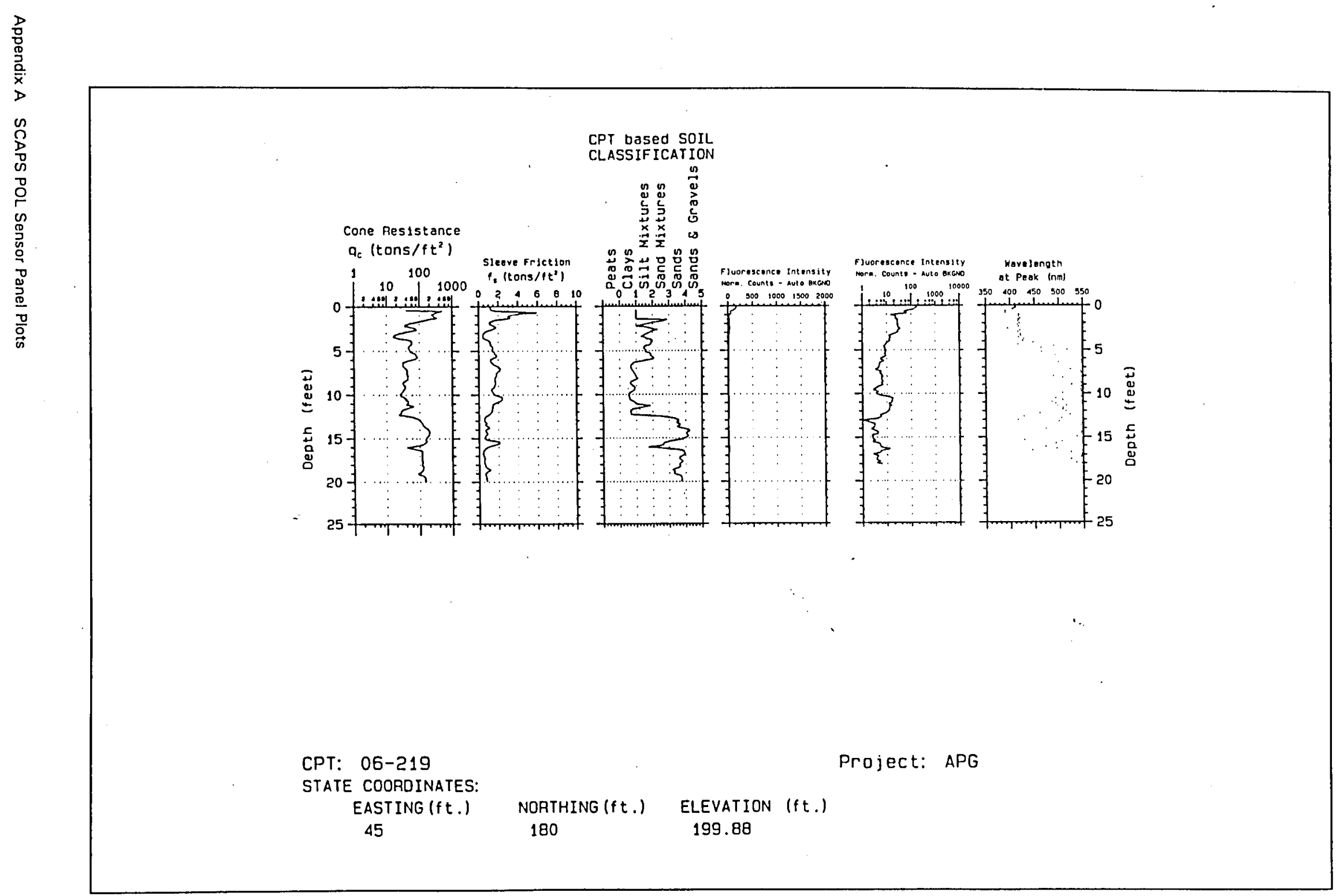

Figure A6. CPT 06-219, Aberdeen Proving Ground 


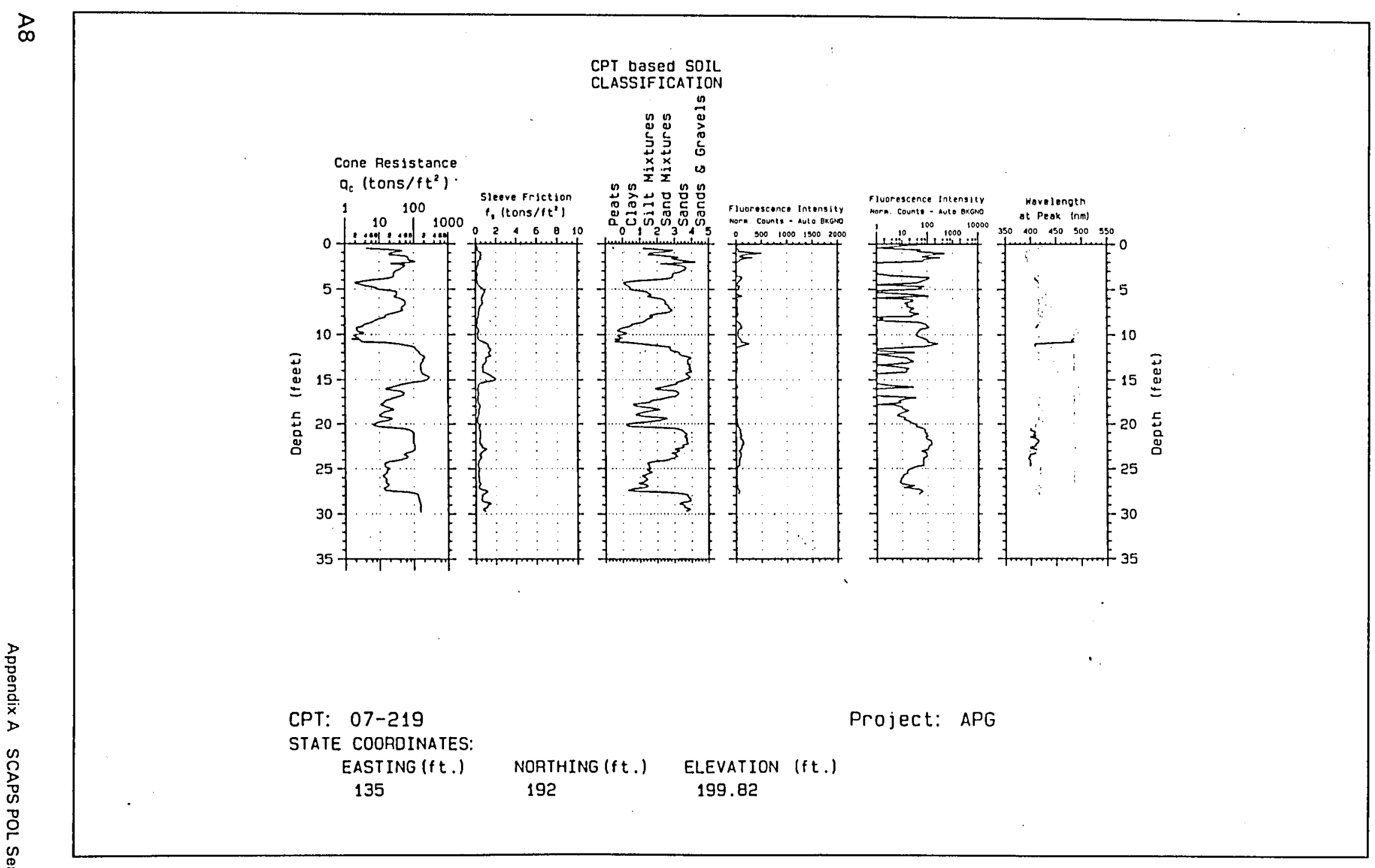

Figure A7. CPT 07-219, Aberdeen Proving Ground 


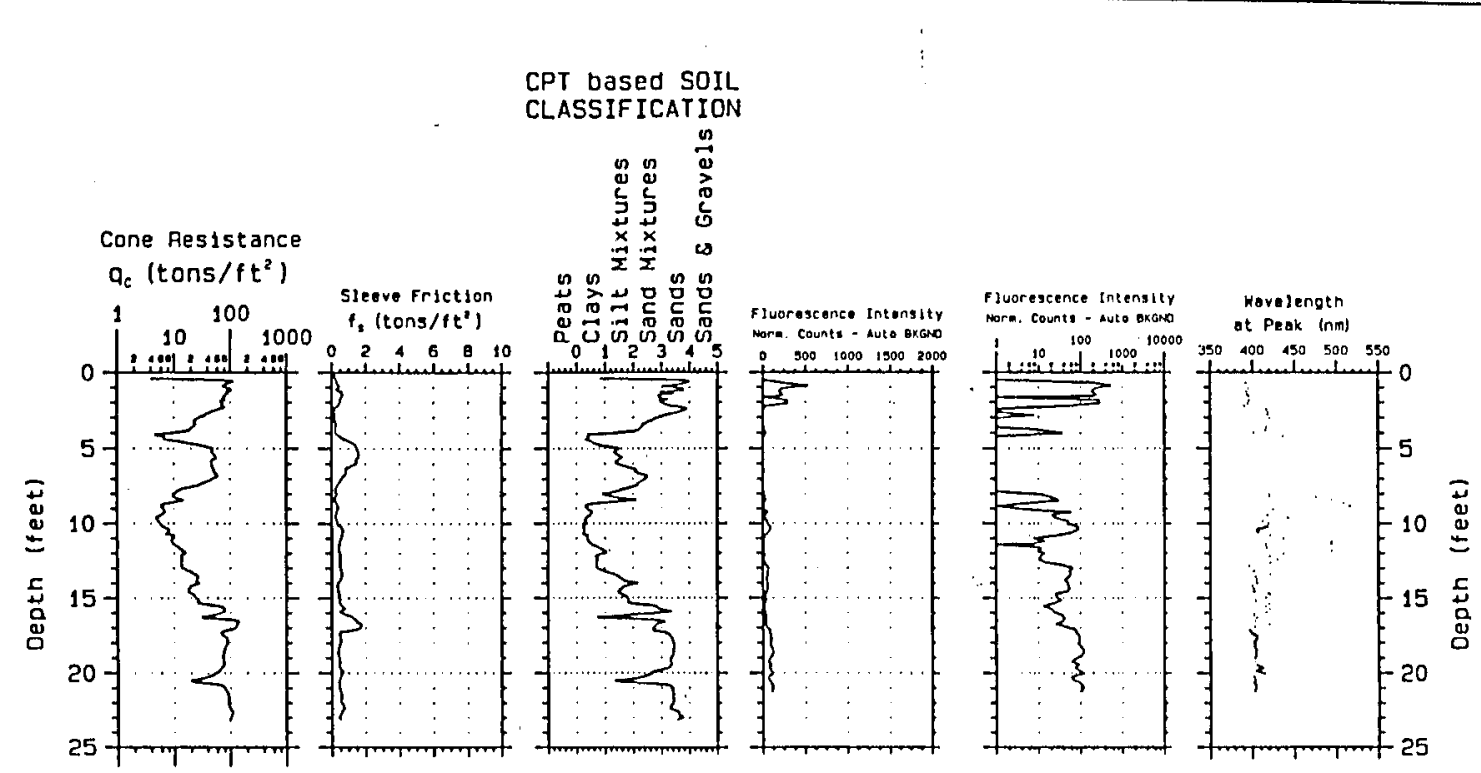

CPT: 08-220

STATE COORDINATES:

EASTING (ft .)

135

NORTHING ( $f$ t .)

217

Project: APG

Figure A8. CPT 08-220, Aberdeen Proving Ground 


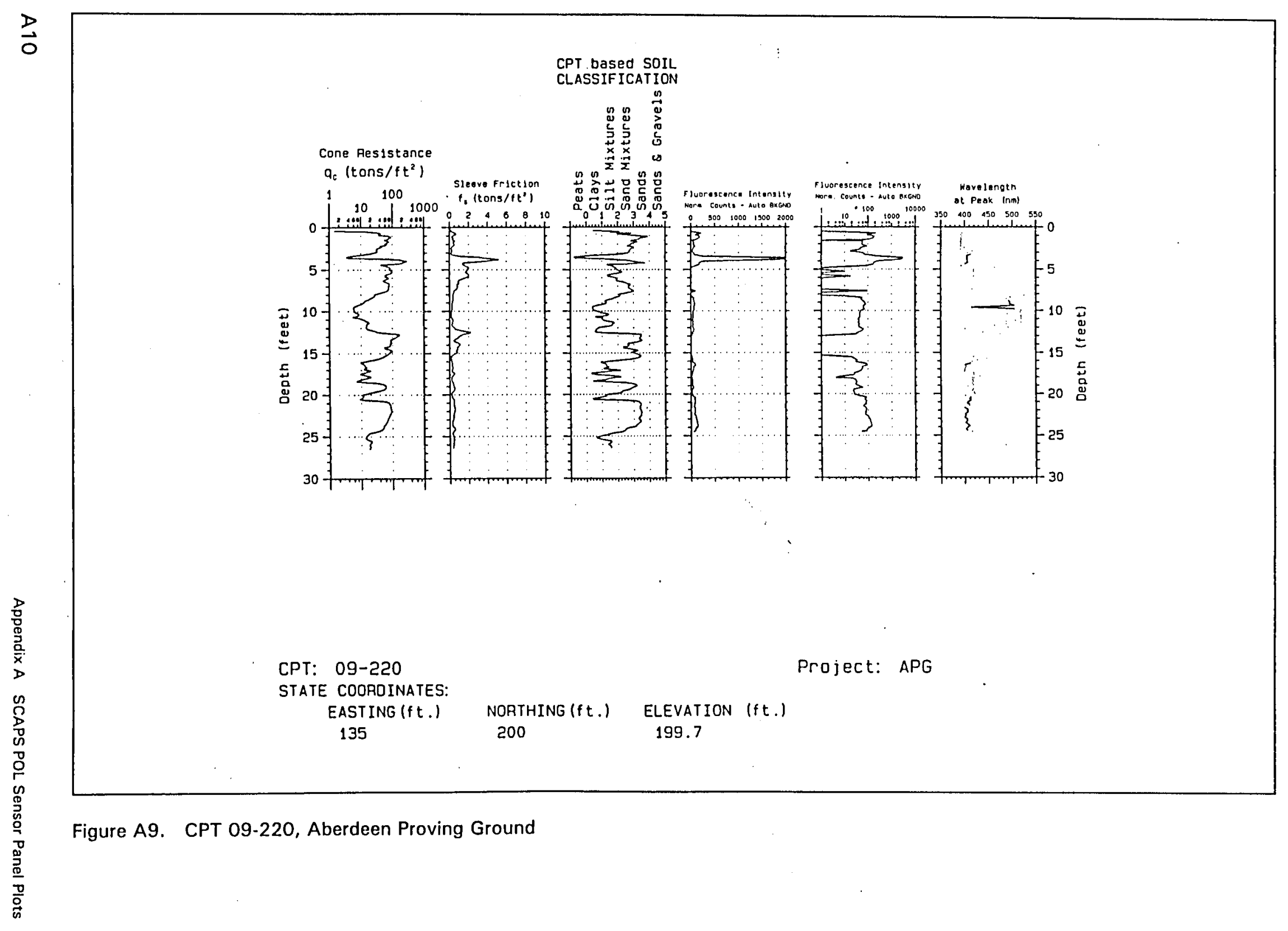




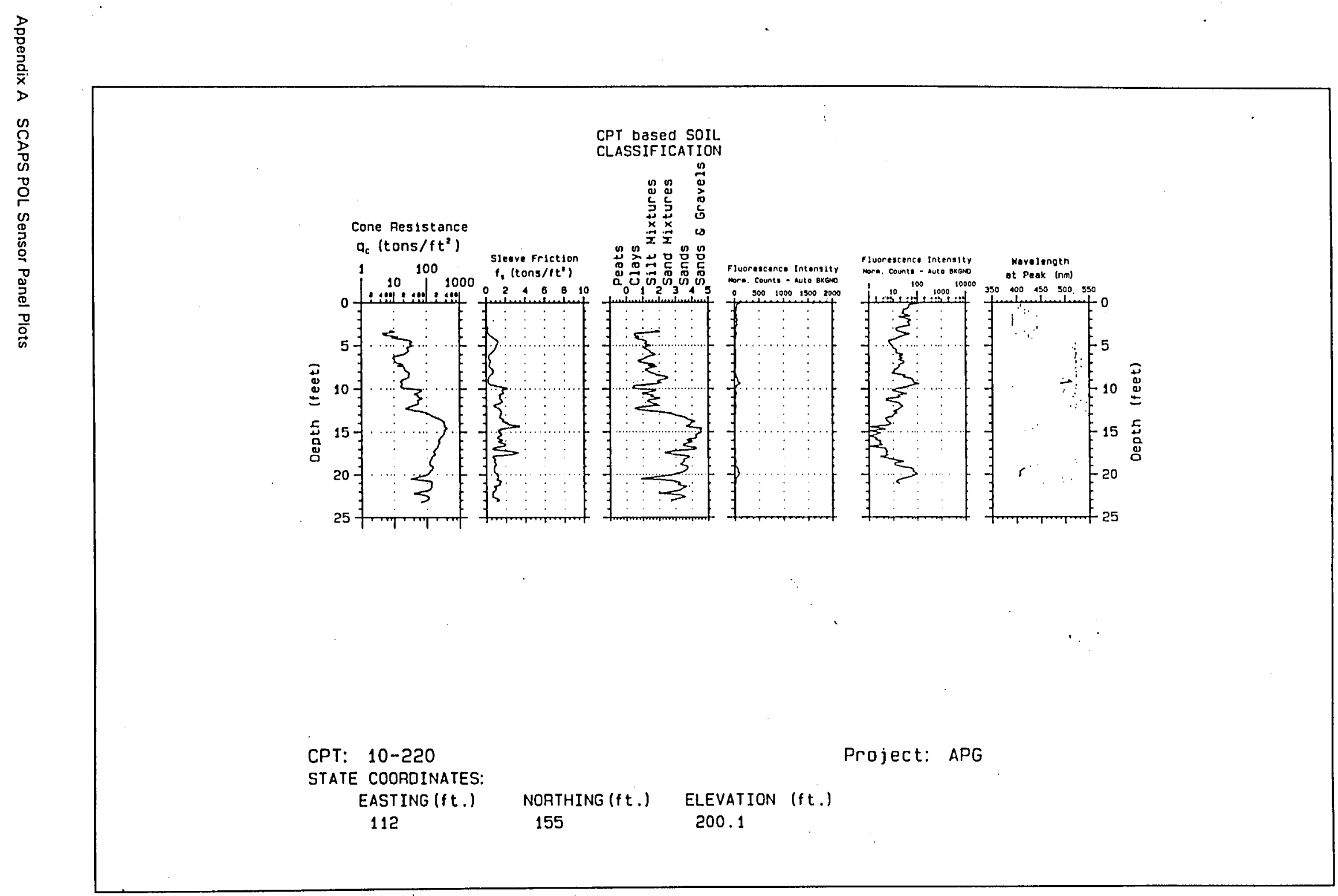

$\stackrel{D}{\rightrightarrows} \quad$ Figure A10. CPT 10-220, Aberdeen Proving Ground 


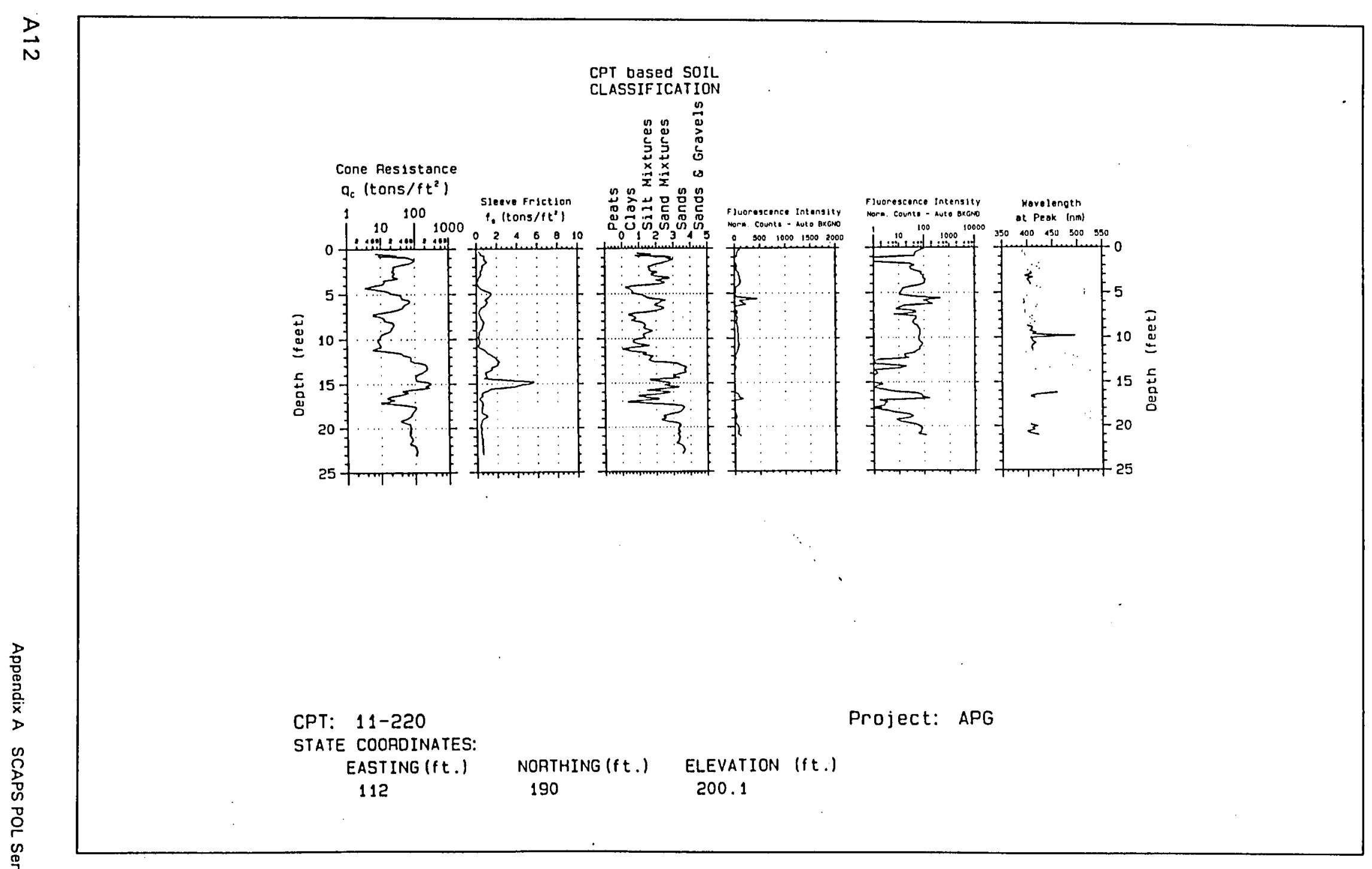

Figure A11. CPT 11-220, Aberdeen Proving Ground 
CPT based SOIL

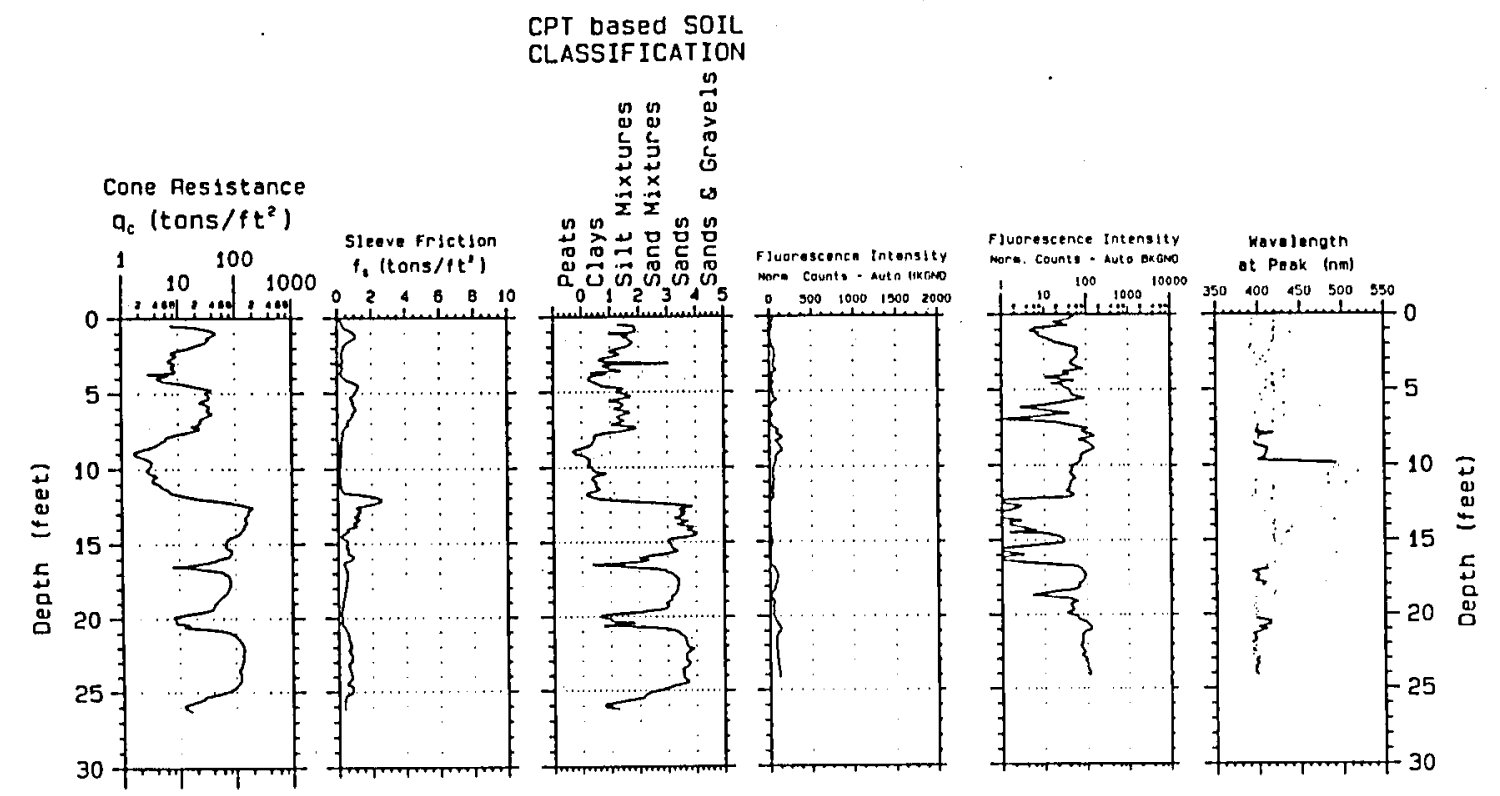

CPT: $12-220$

STATE COORDINATES:

EASTING ( $f \mathrm{t}$. )

180

NORTHING ( $\mathrm{ft}$.)

195

Project: APG

$\vec{\omega}$

Figure A12. CPT 12-220, Aberdeen Proving Ground 


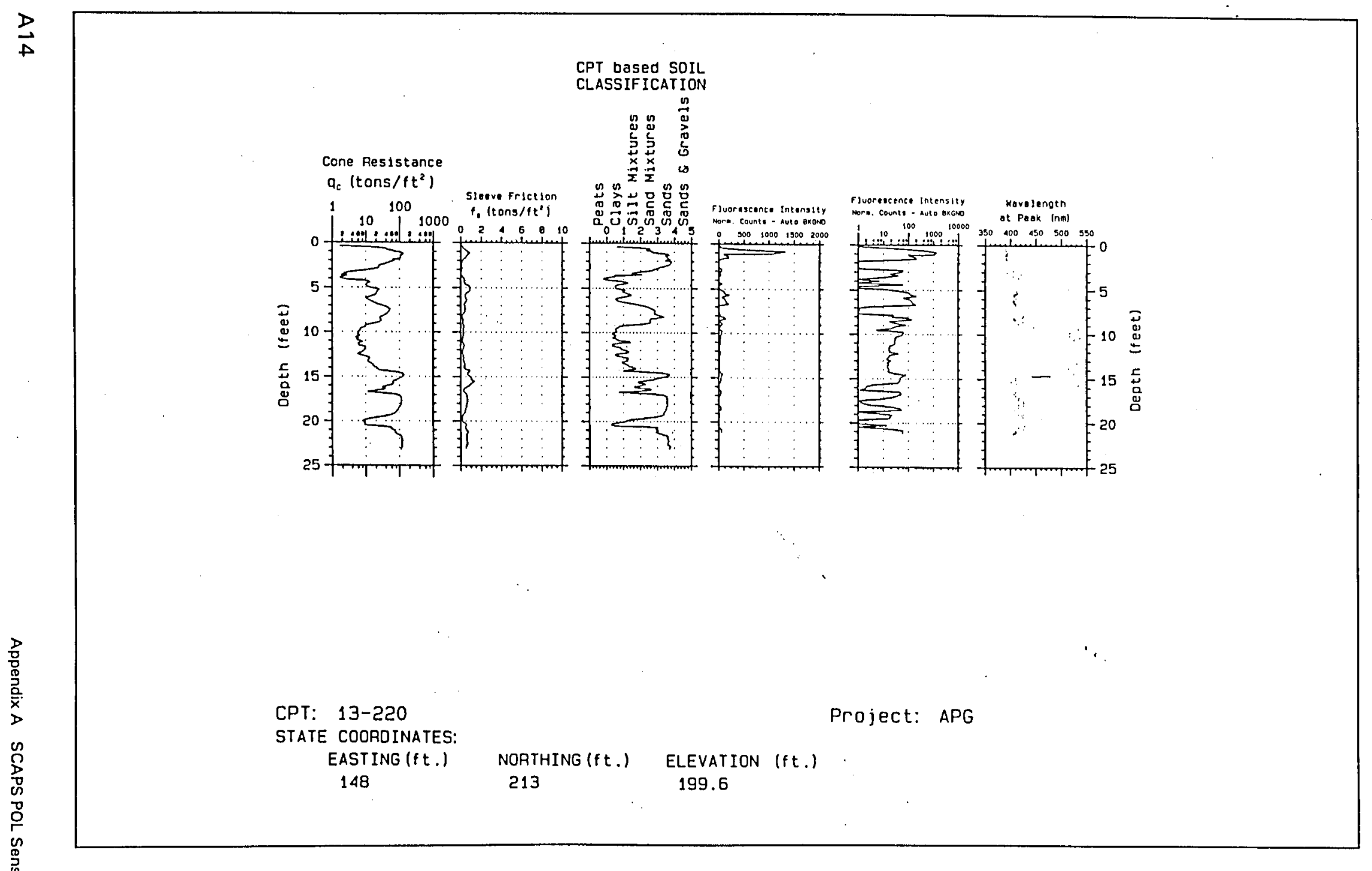

Figure A13. CPT 13-220, Aberdeen Proving Ground 


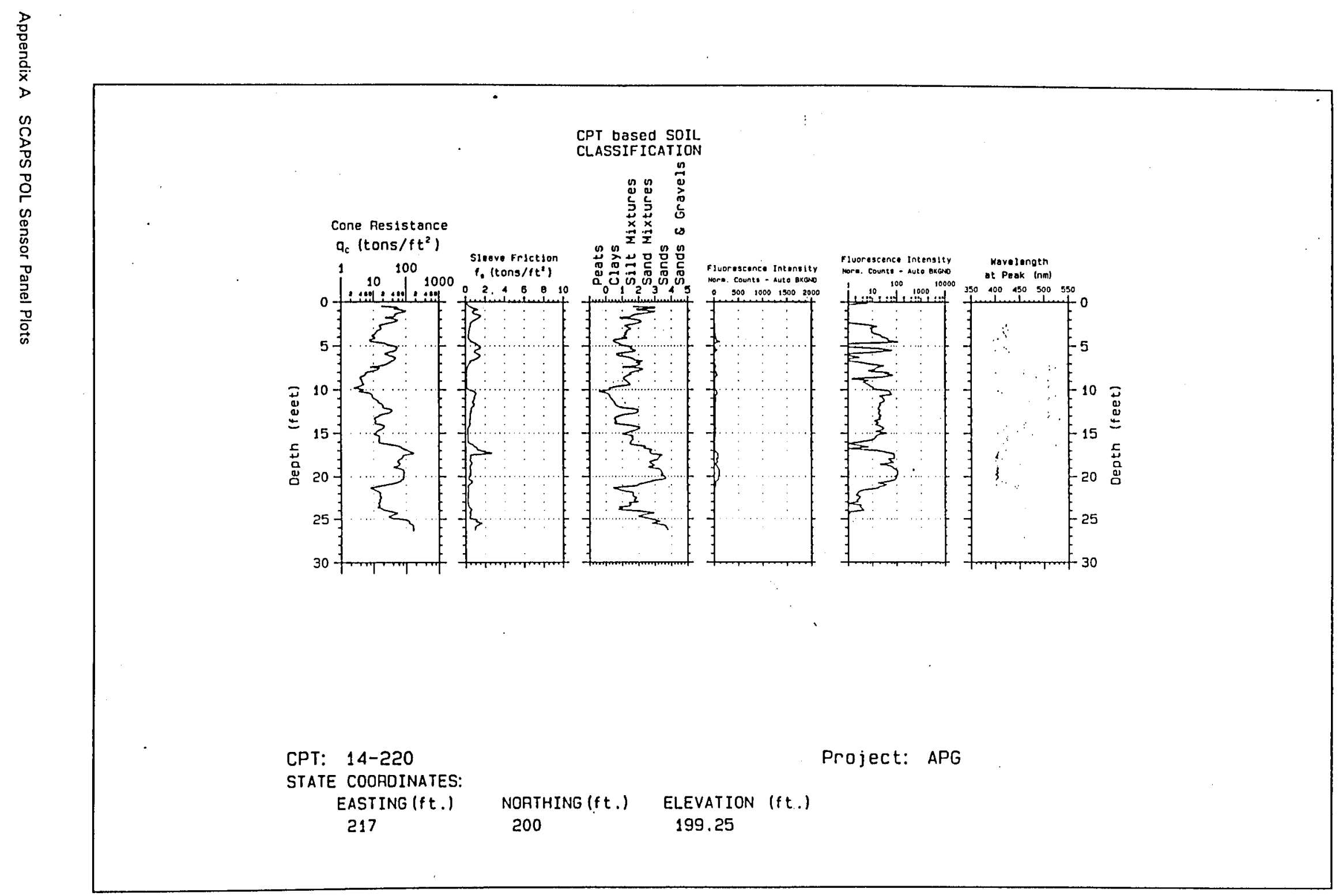




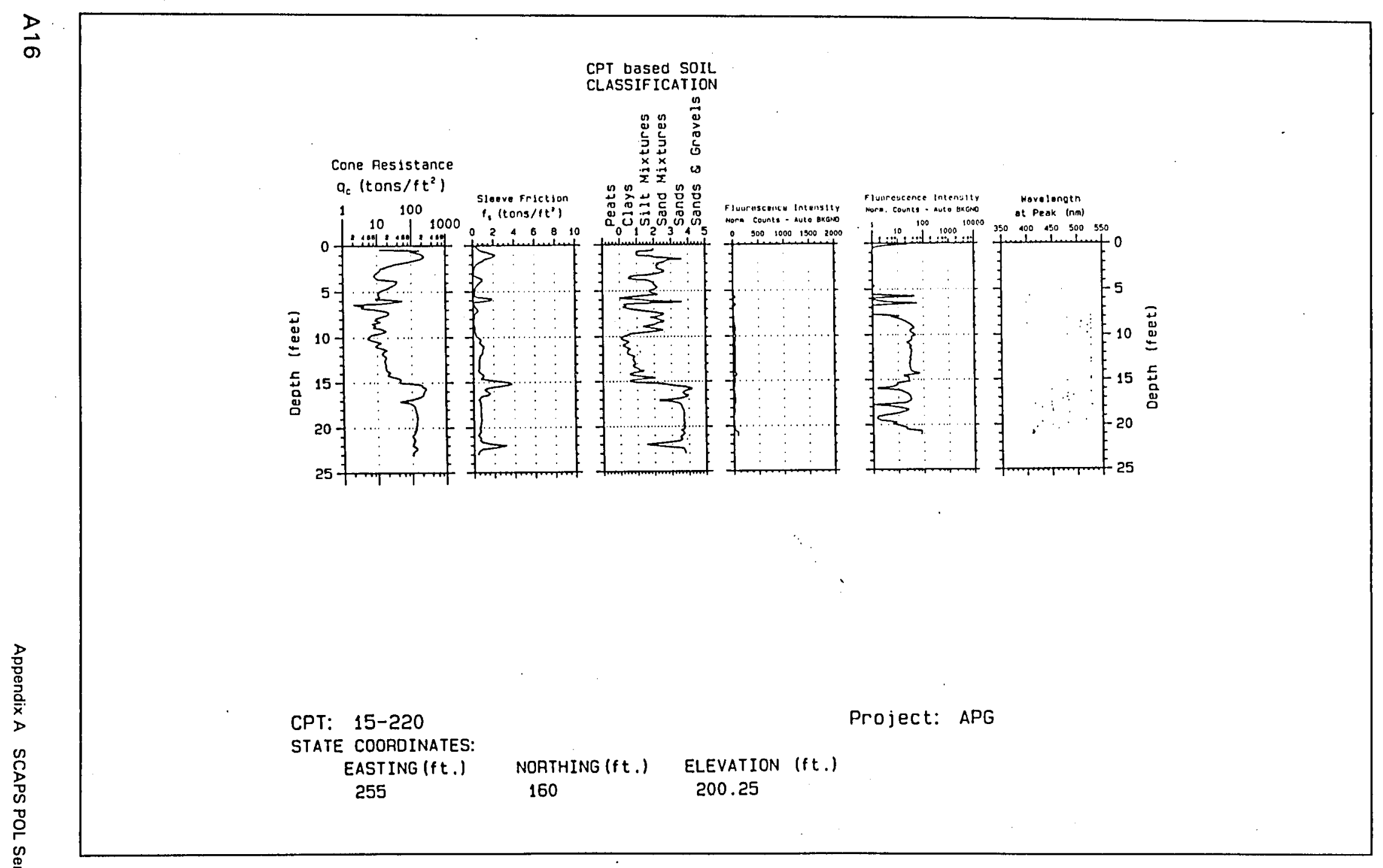

Figure A15. CPT 15-220, Aberdeen Proving Ground 


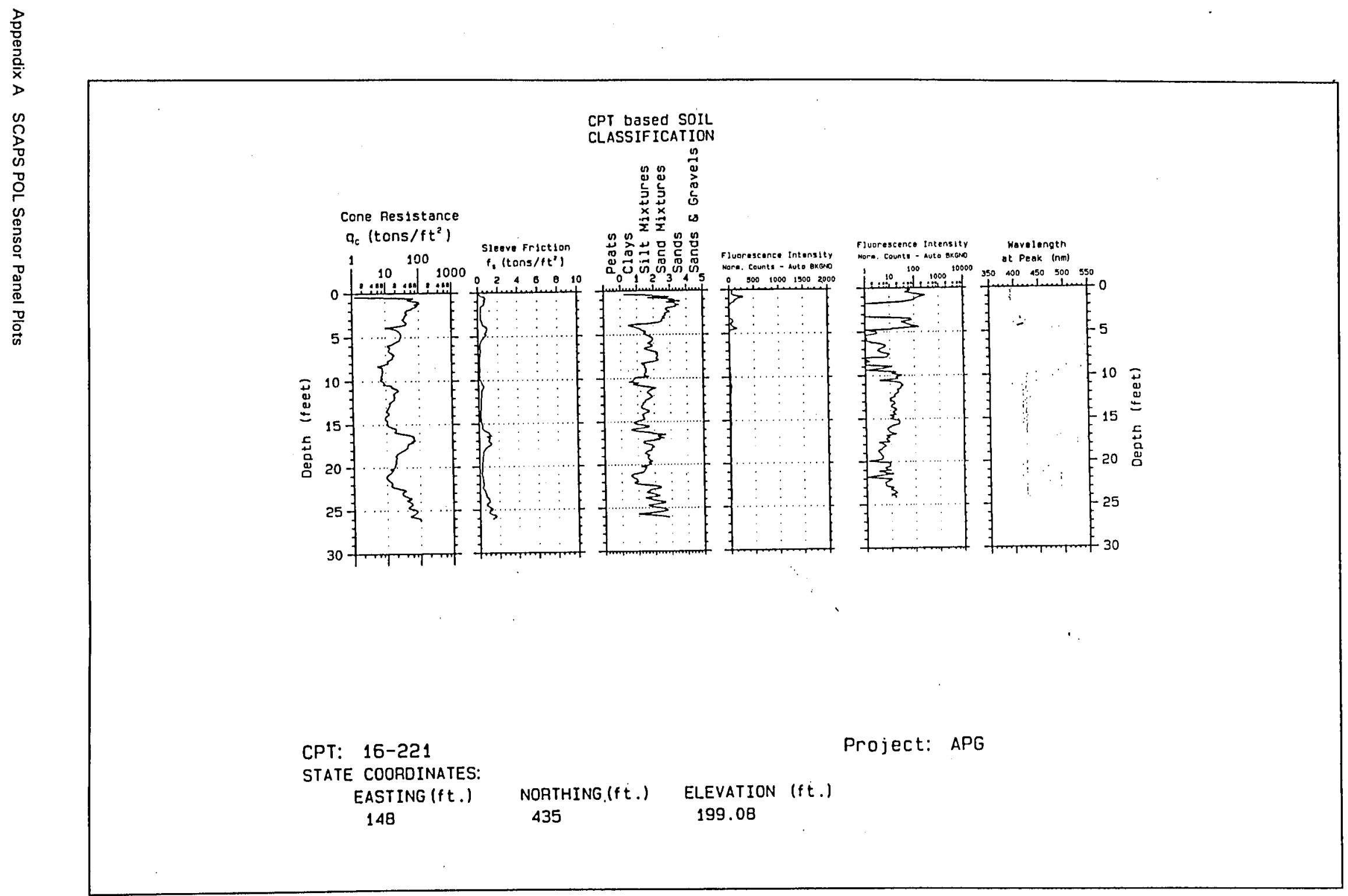




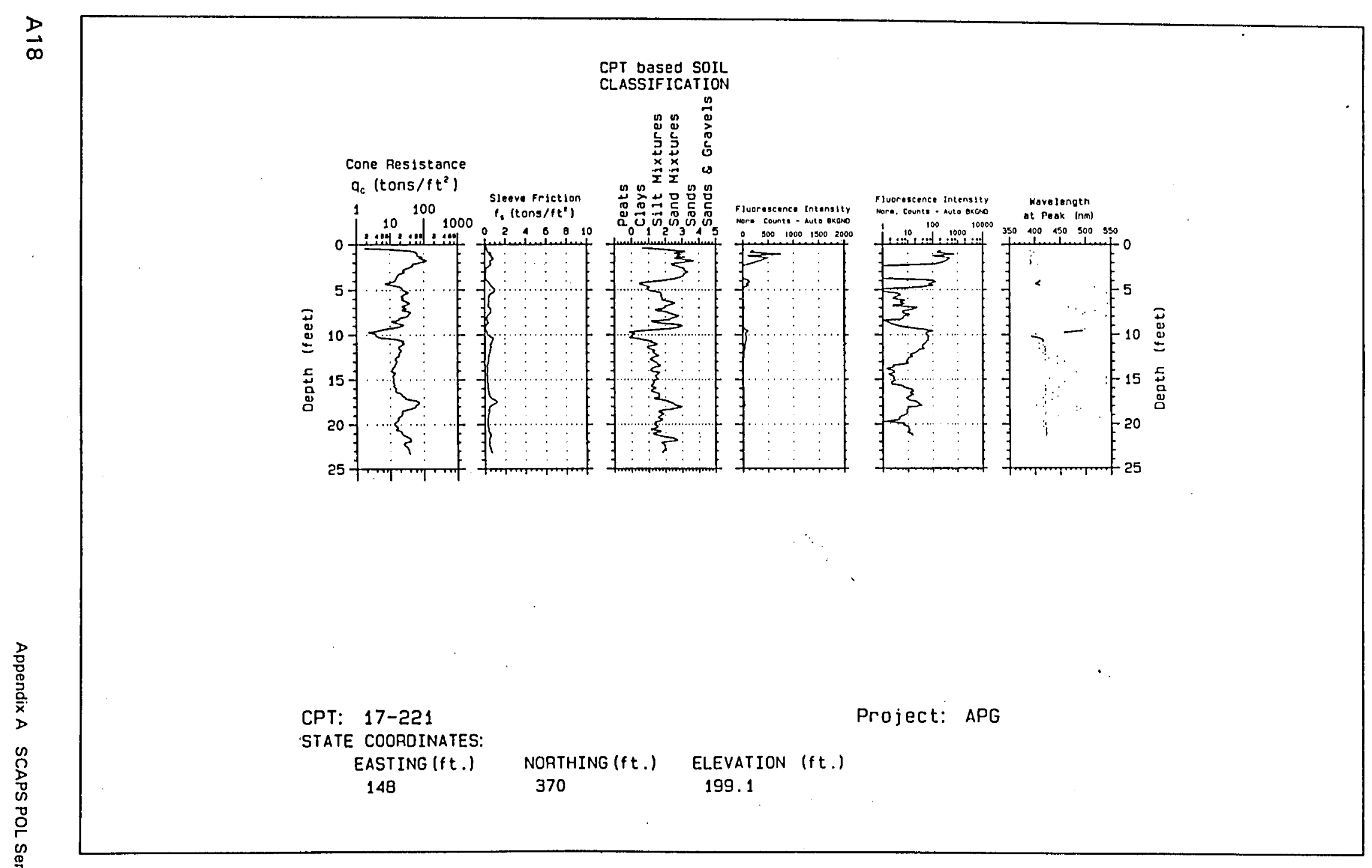

Figure A17. CPT 17-221, Aberdeen Proving Ground 


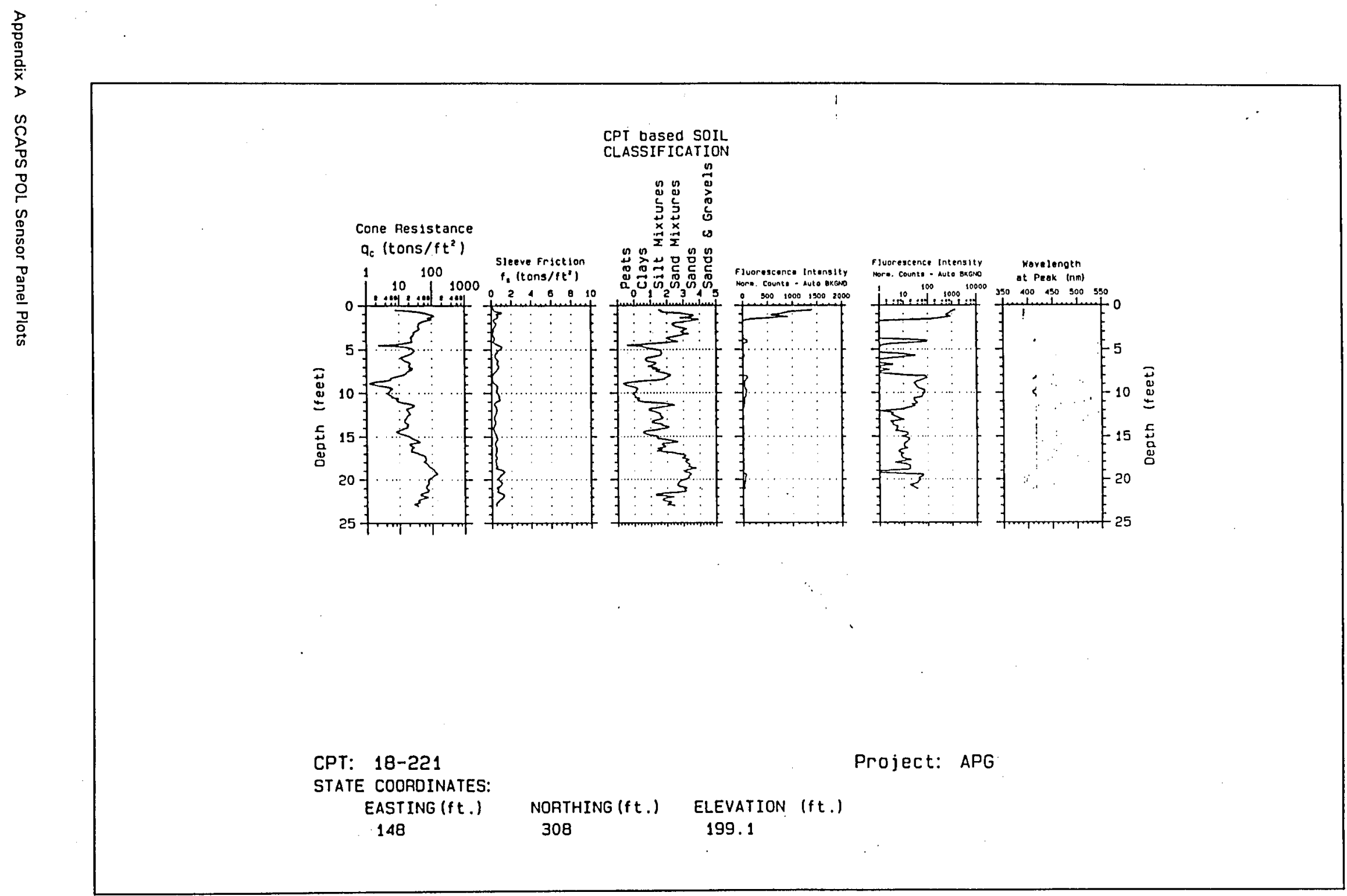




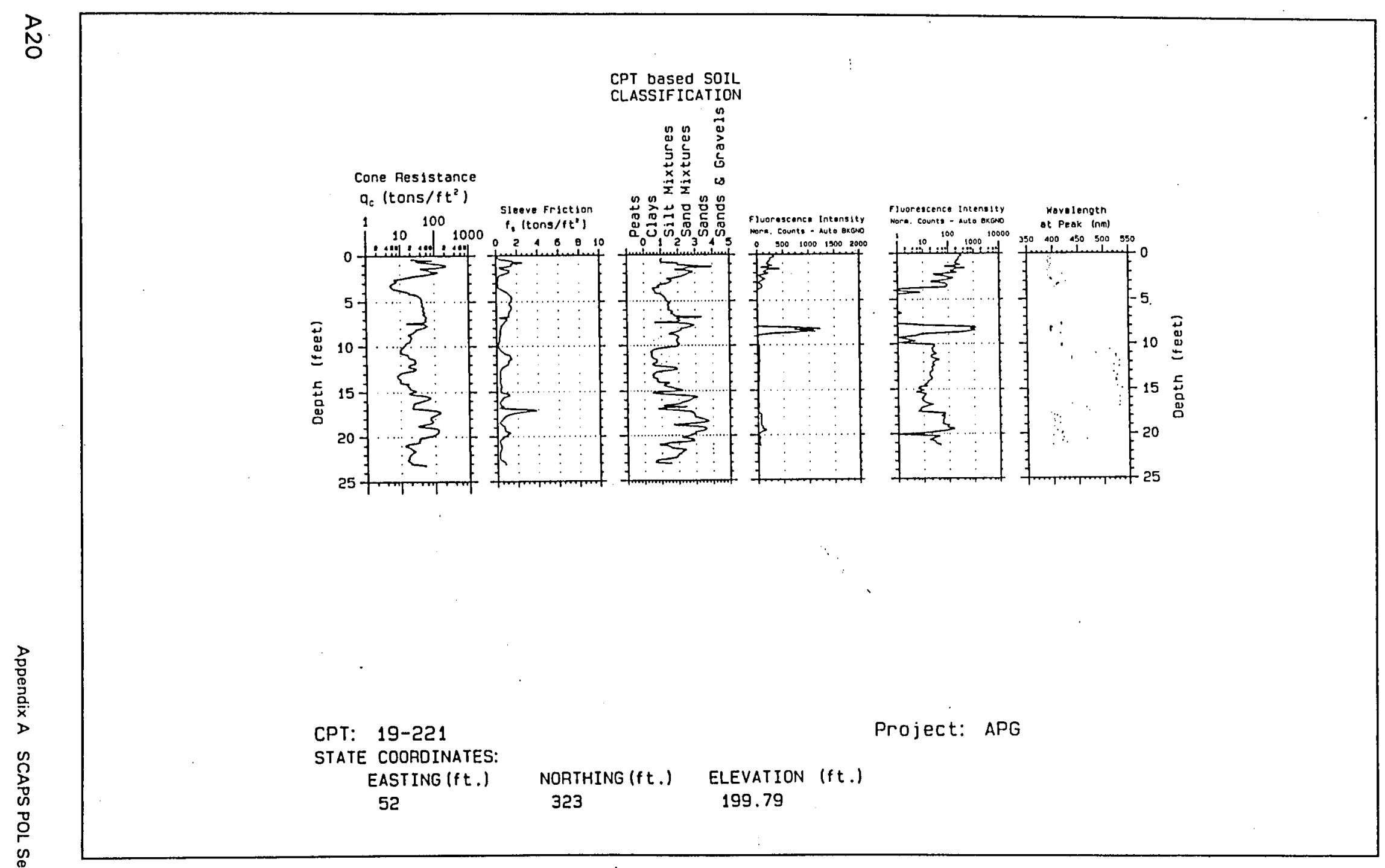

Figure A19. CPT 19-221, Aberdeen Proving Ground 


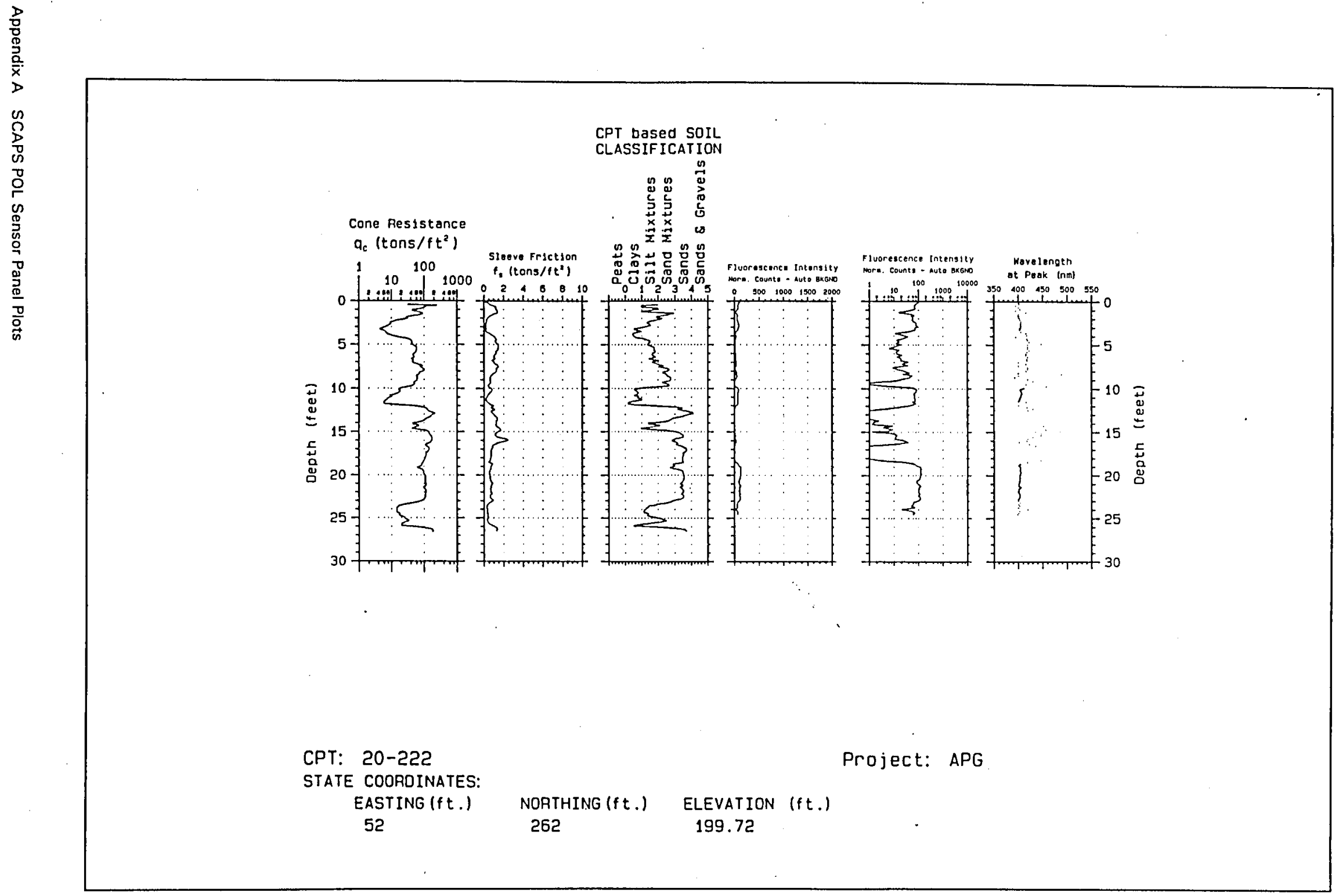




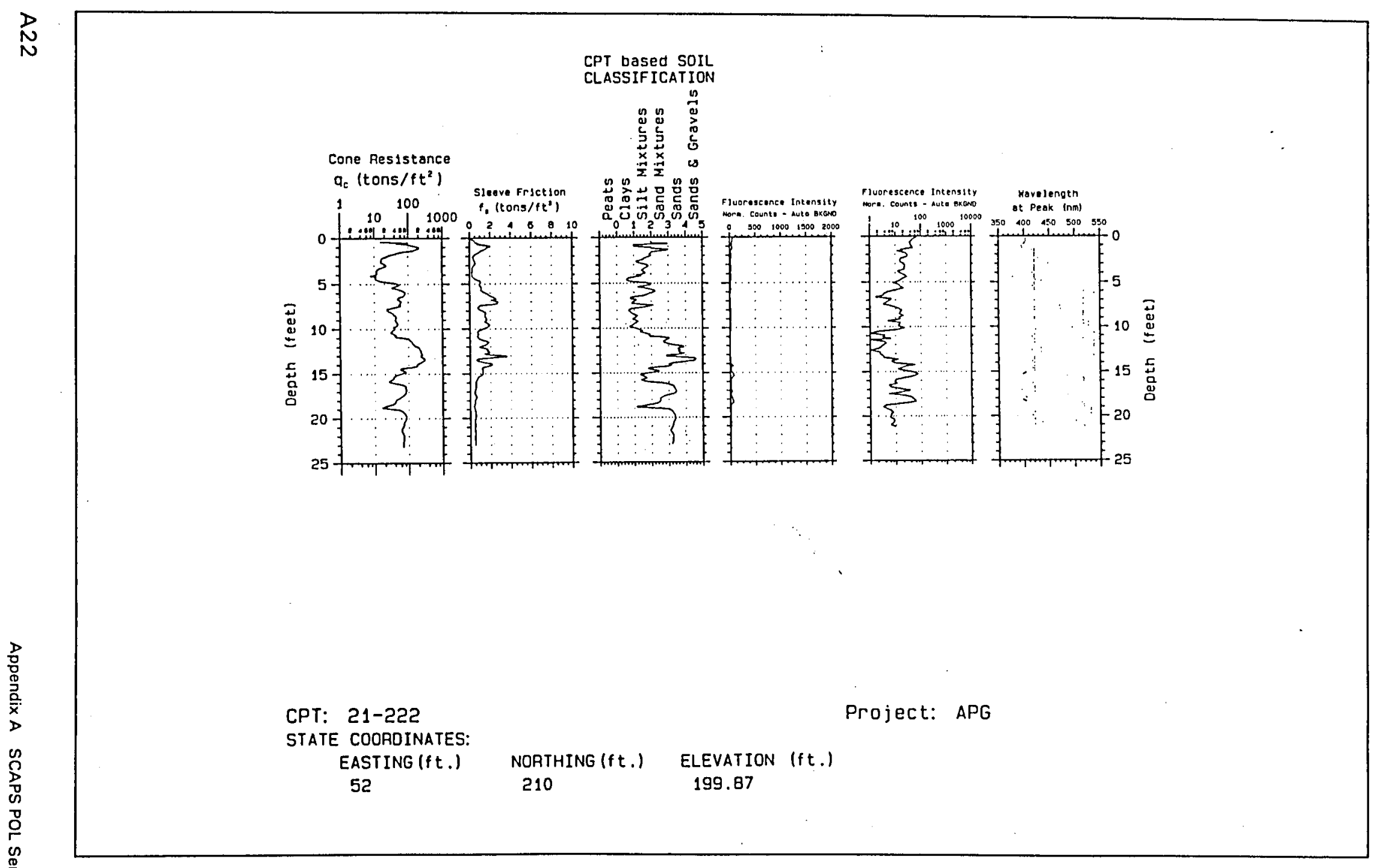

Figure A21. CPT 21-222, Aberdeen Proving Ground 


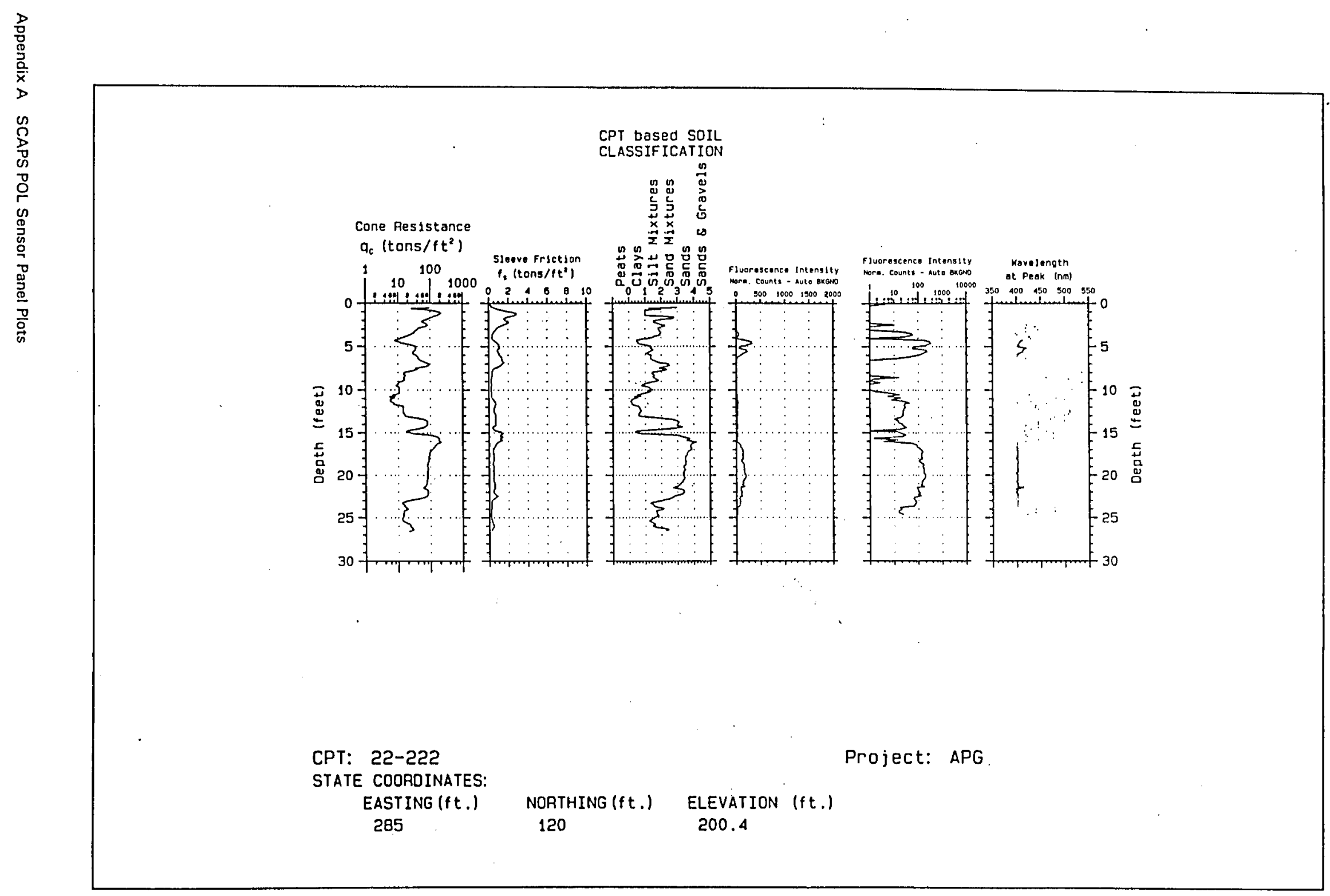




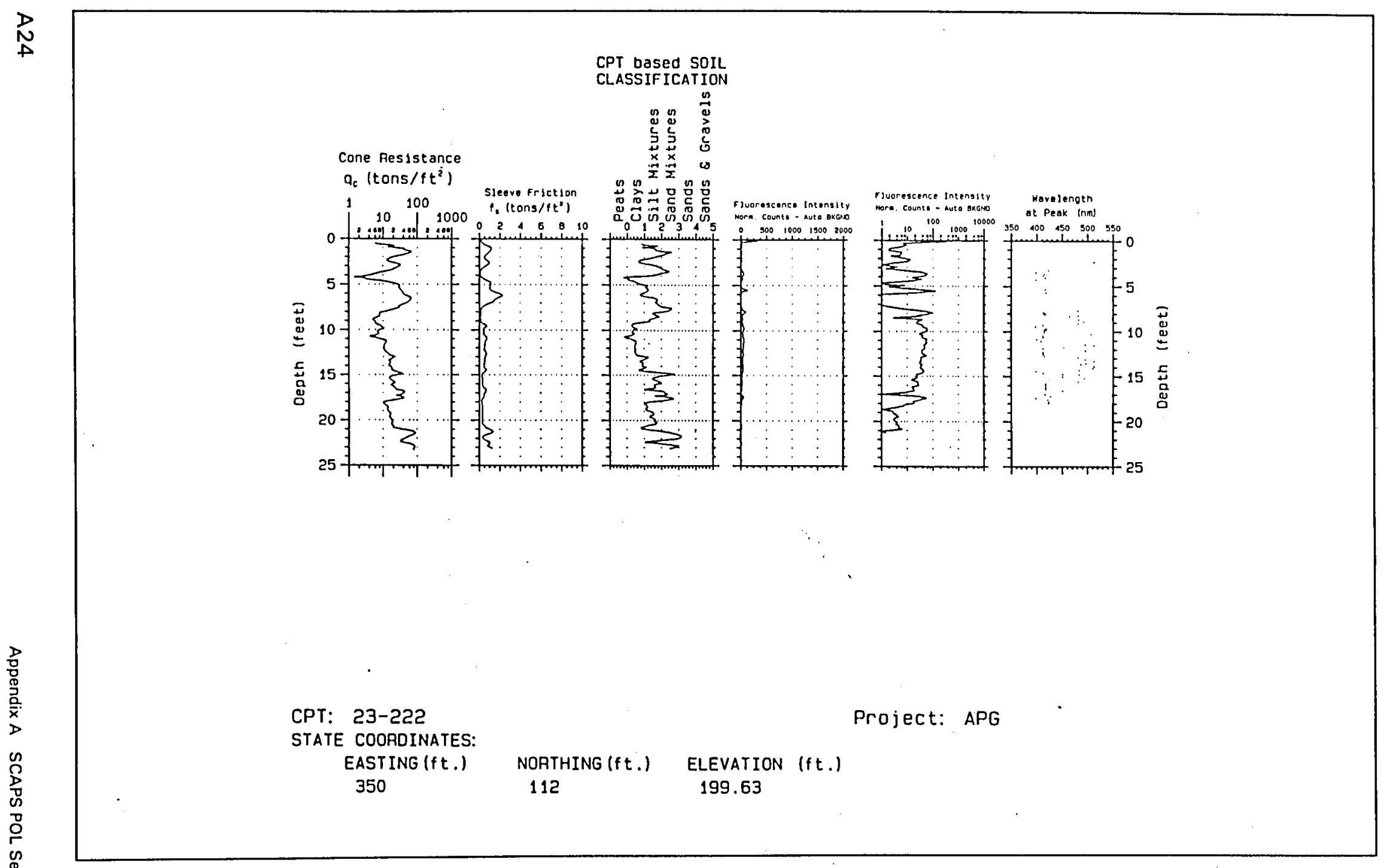

Figure A23. CPT 23-222, Aberdeen Proving Ground 


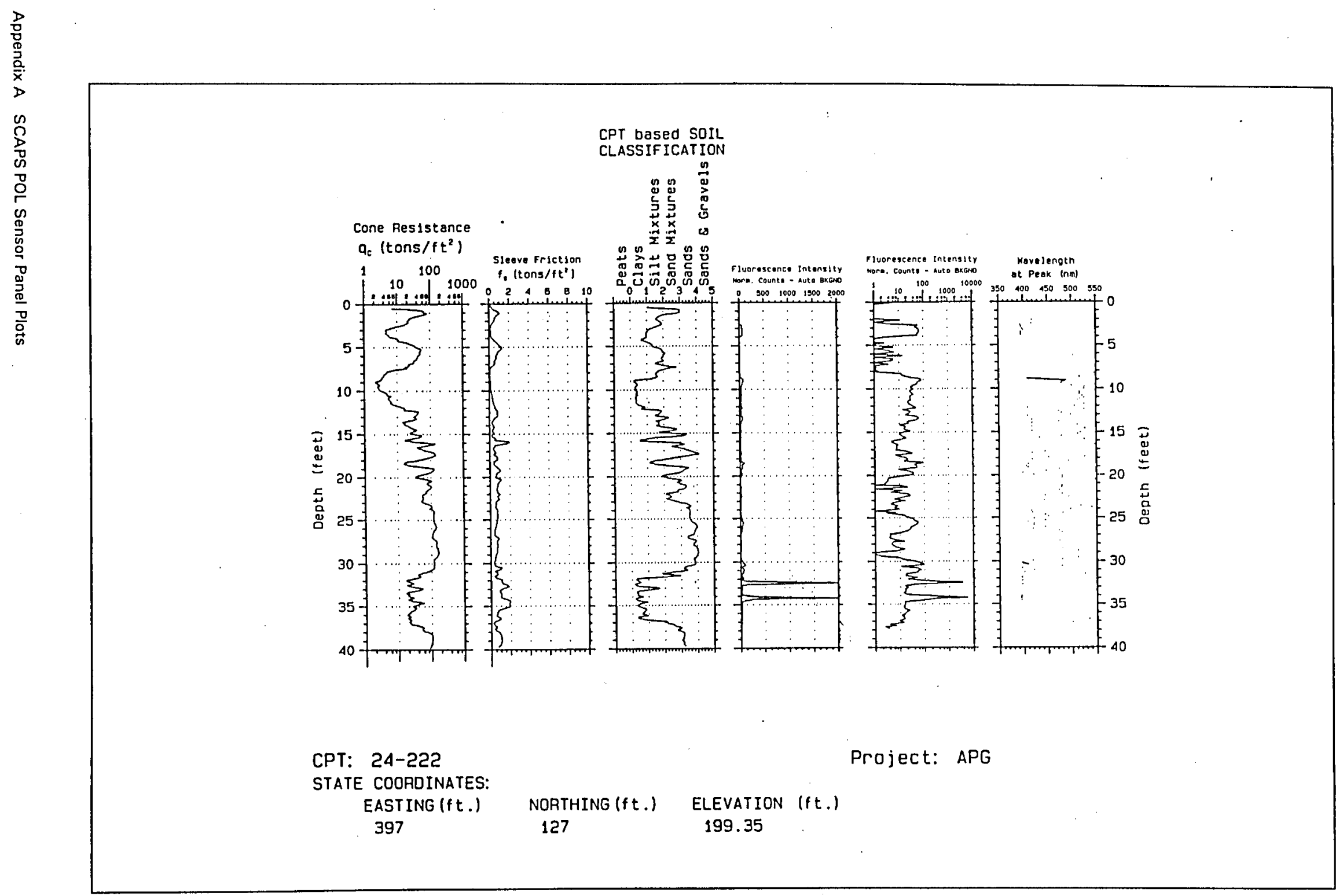

N Figure A24. CPT 24-222, Aberdeen Proving Ground 


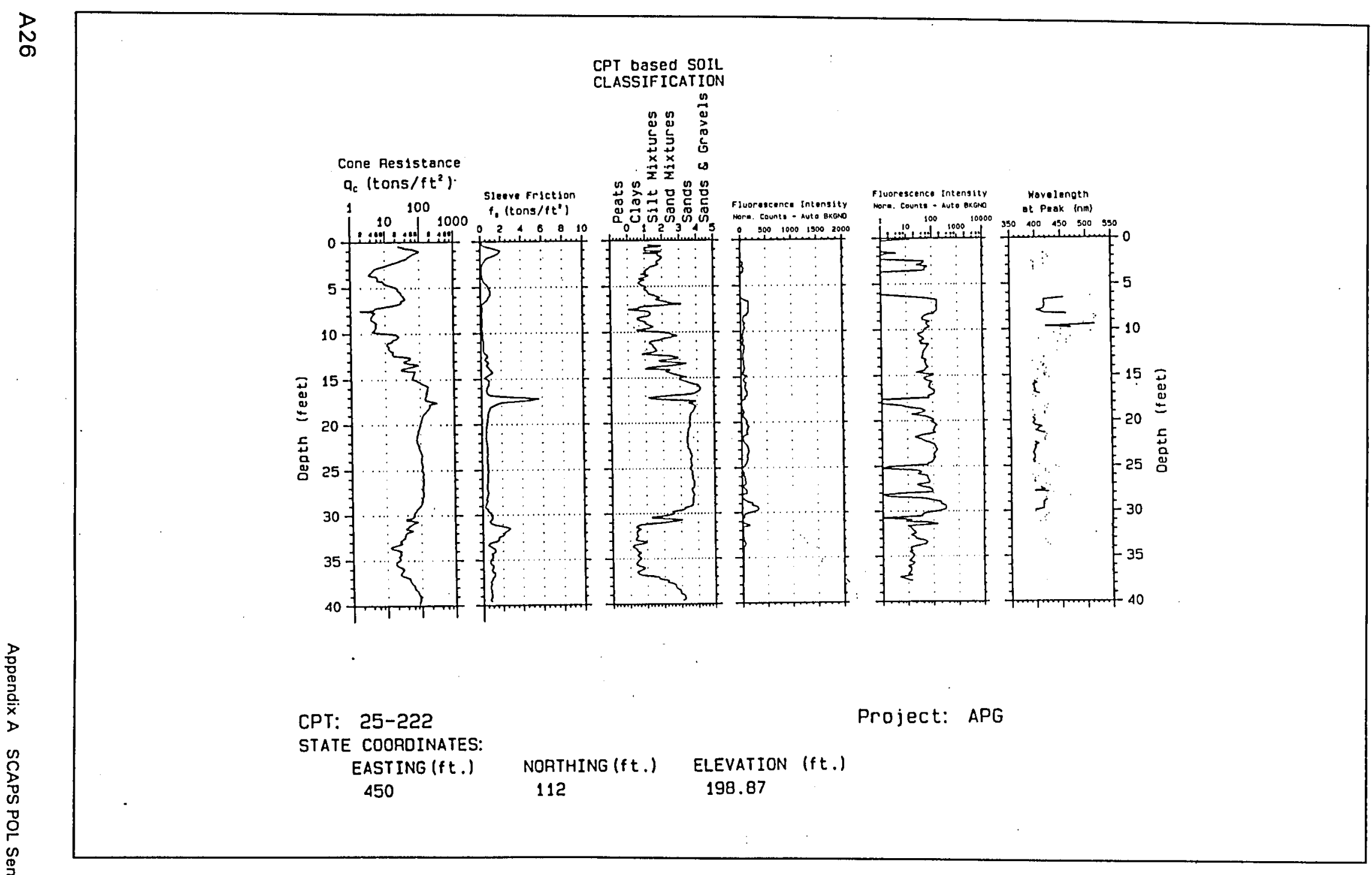

Figure A25. CPT 25-222, Aberdeen Proving Ground 


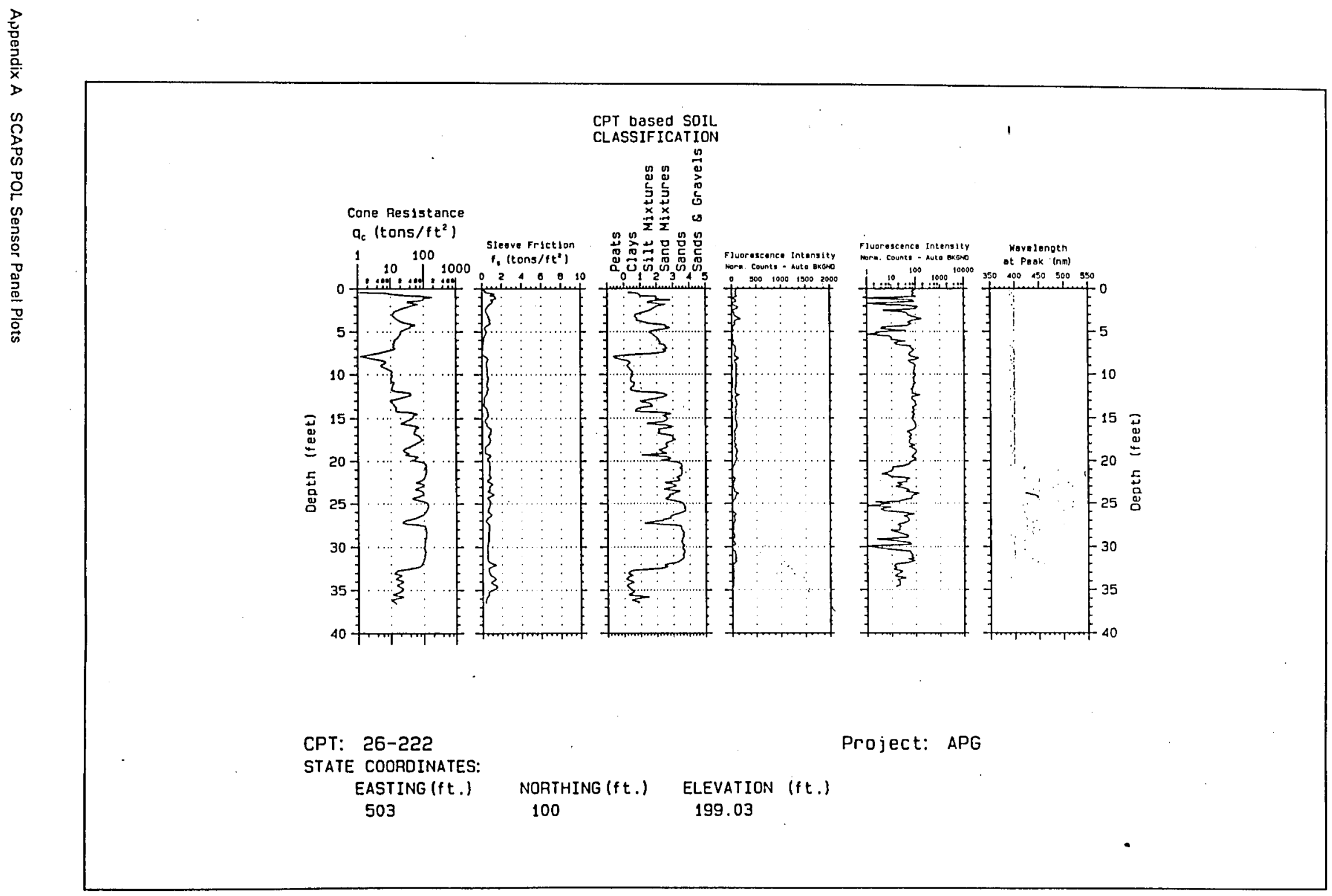

Figure A26. СРT 26-222, Aberdeen Proving Ground 


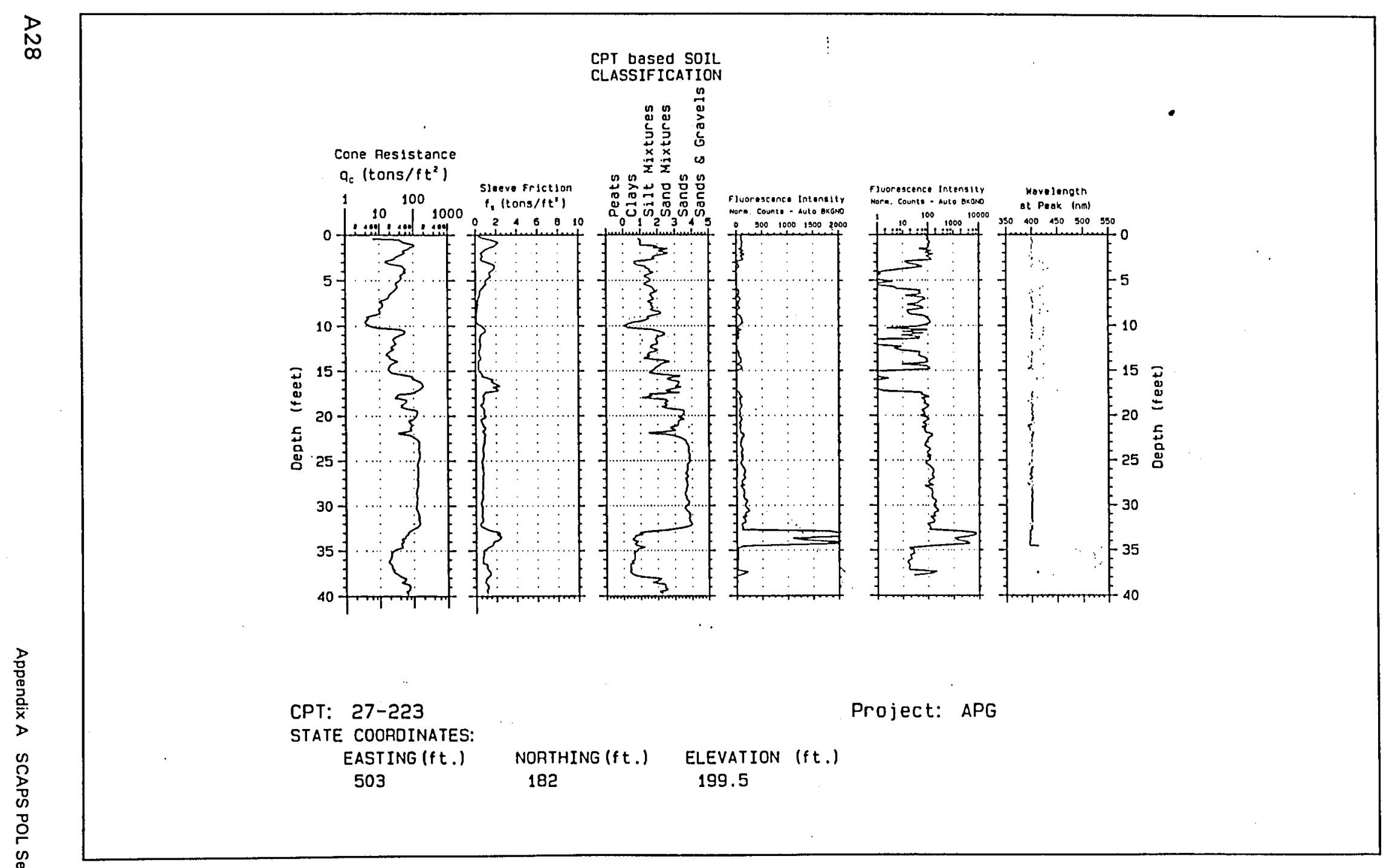

Figure A27. CPT 27-223, Aberdeen Proving Ground 


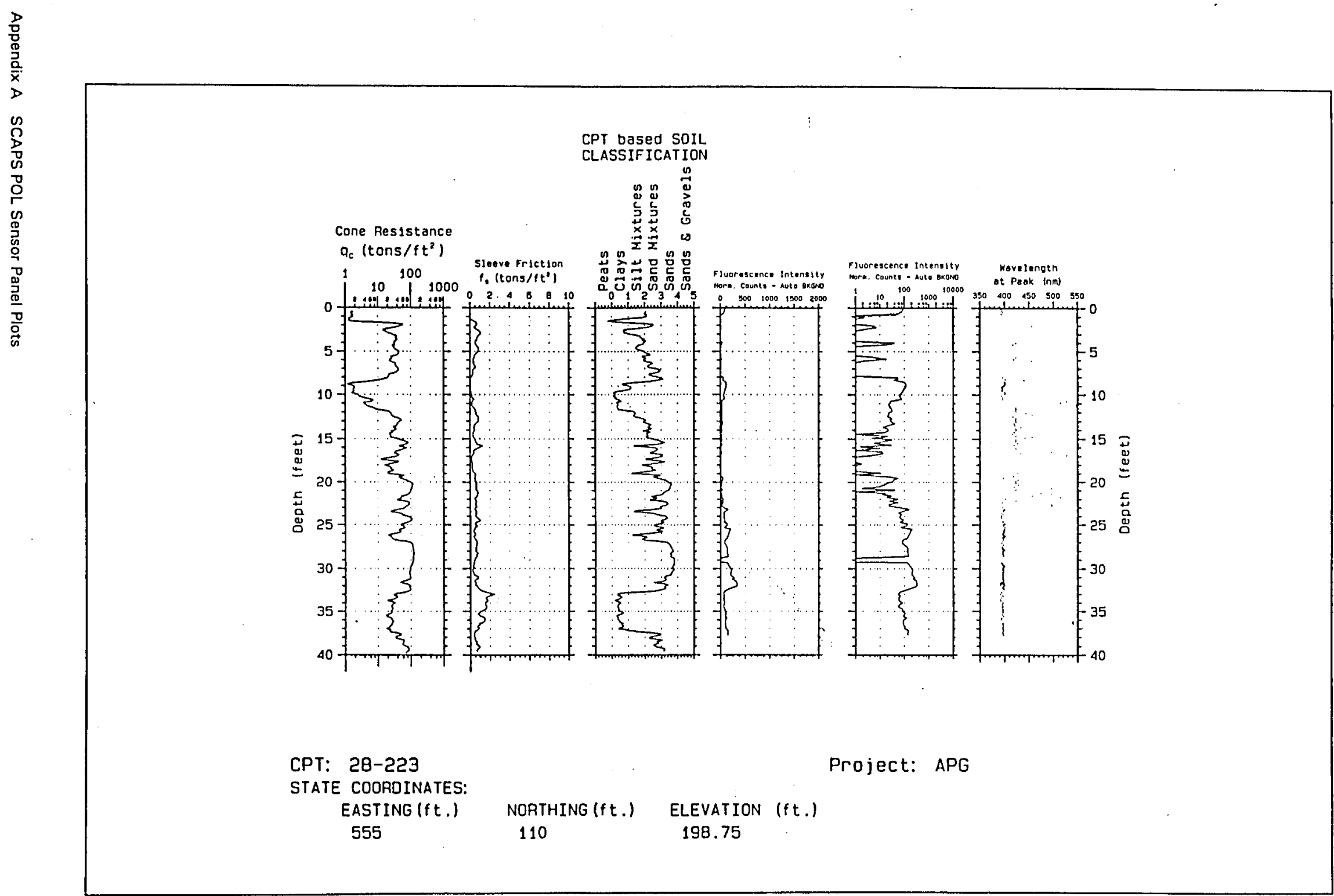




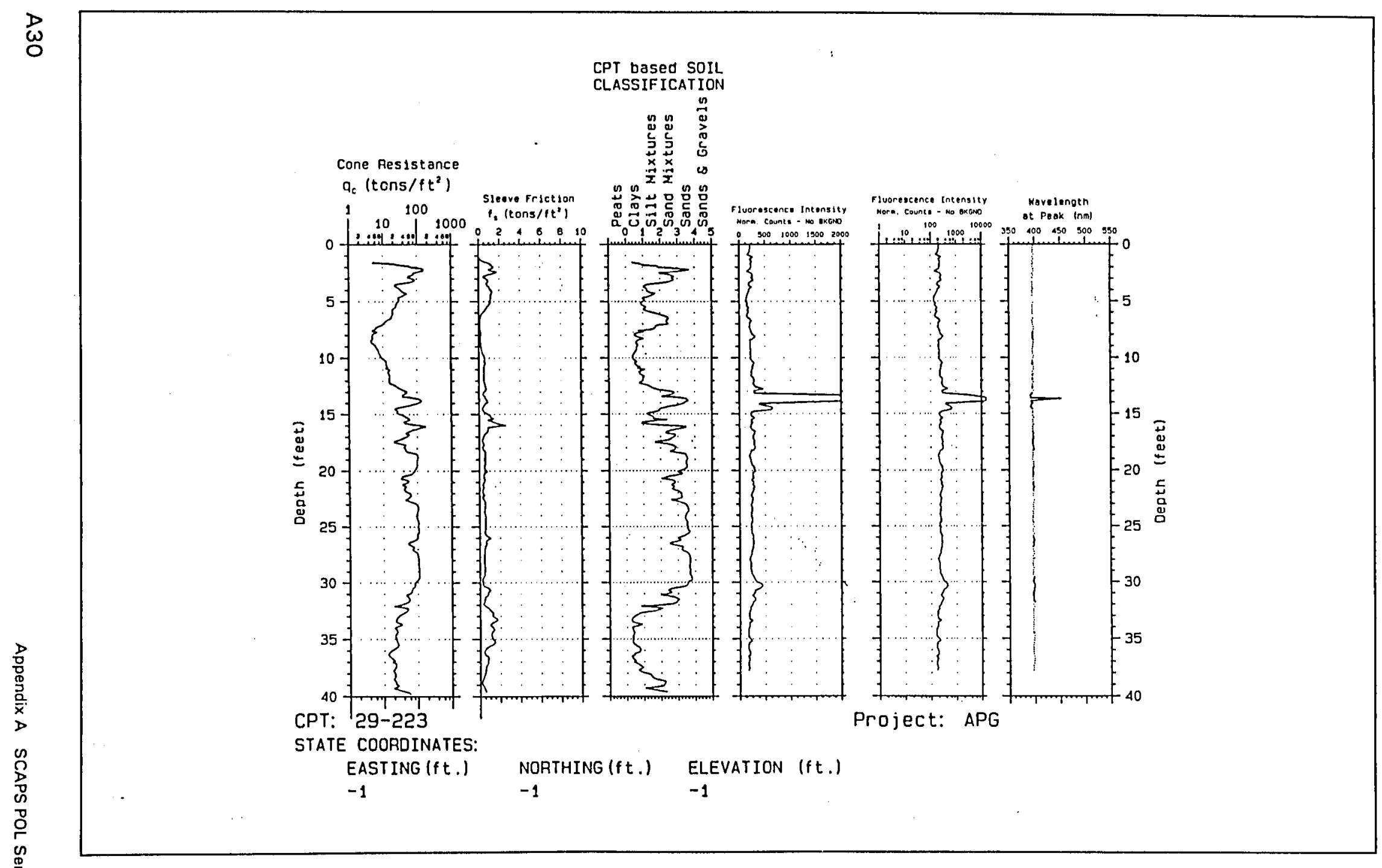

Figure A29. CPT 29-223, Aberdeen Proving Ground 


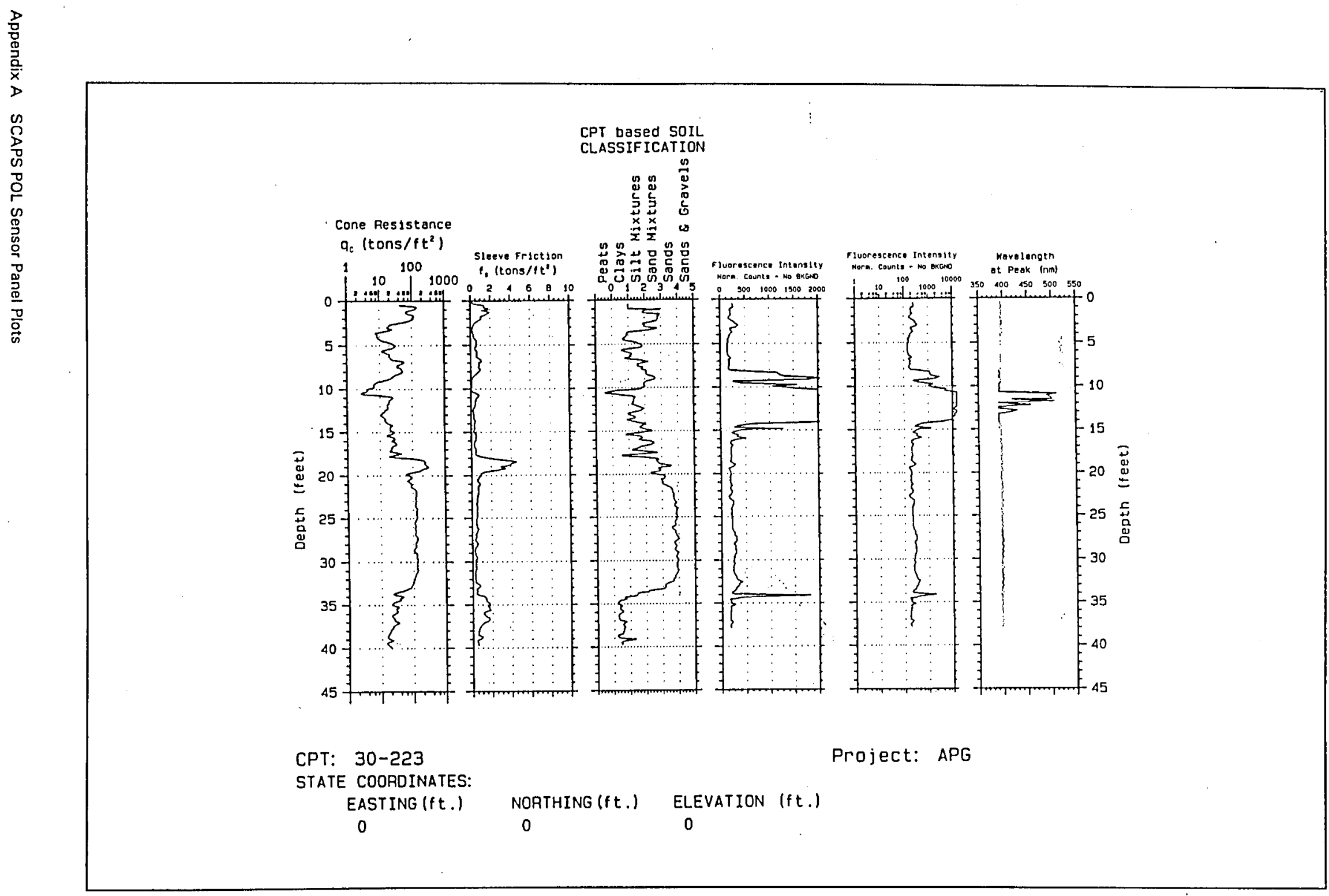




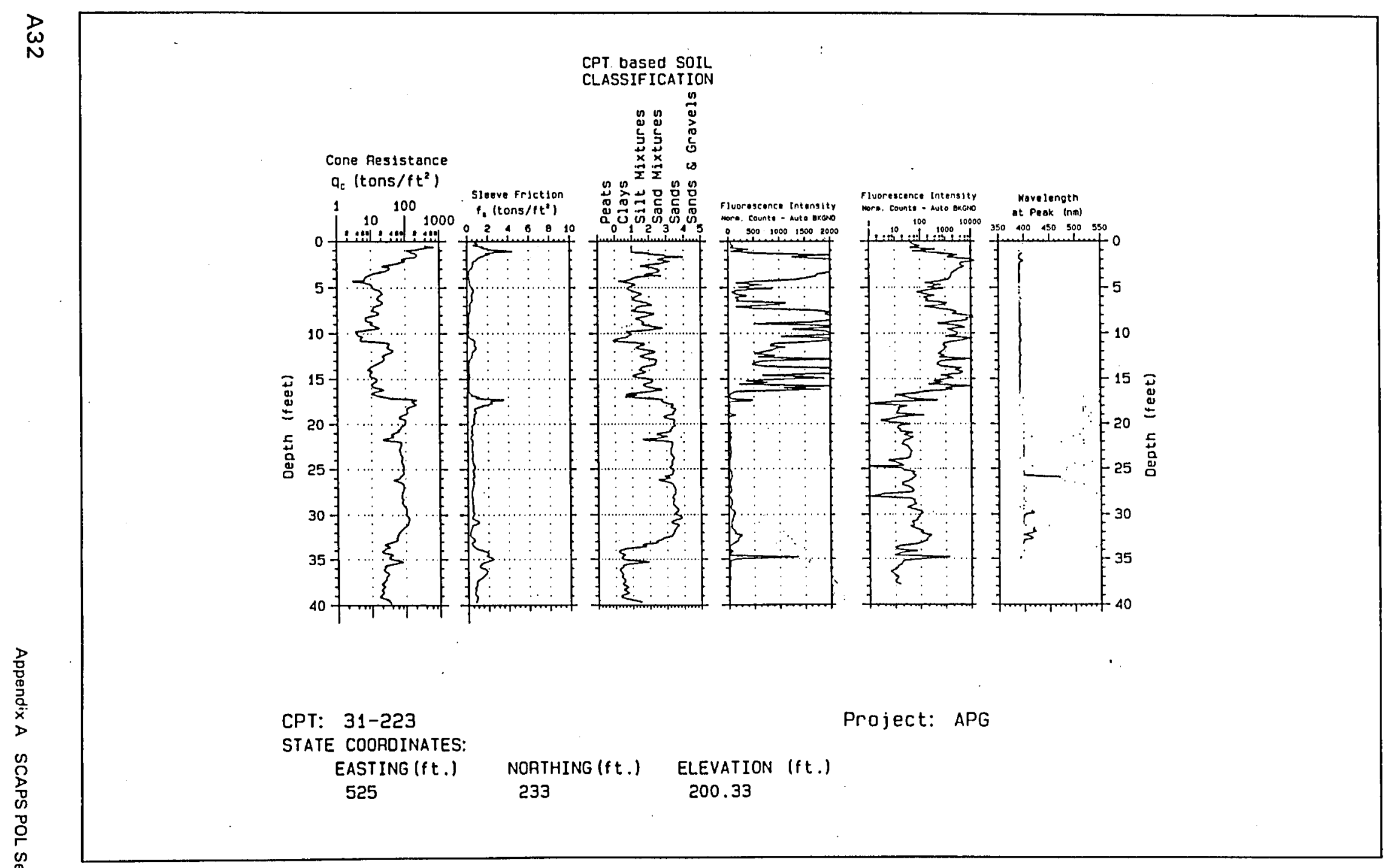

Figure A31. CPT 31-223, Aberdeen Proving Ground 


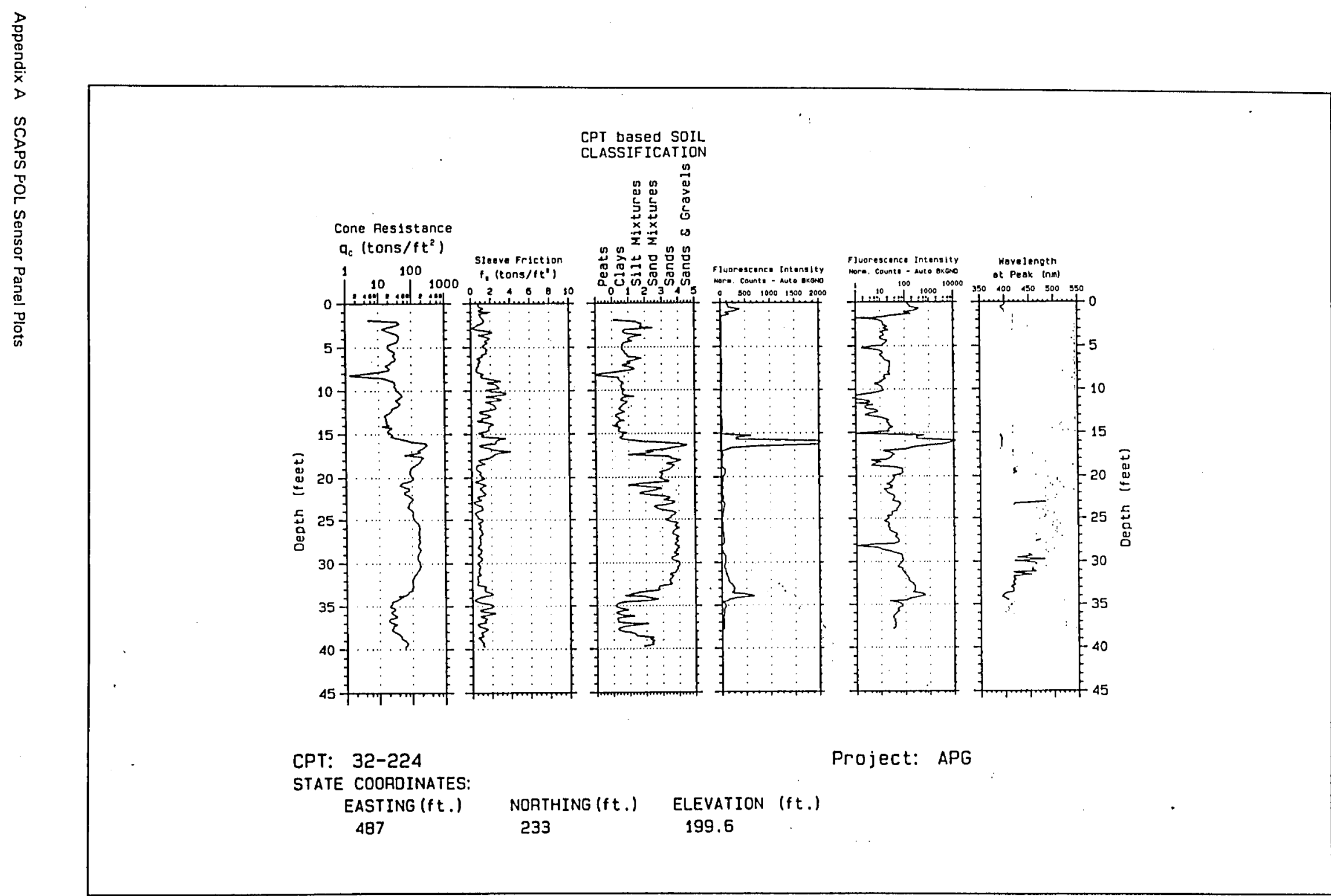




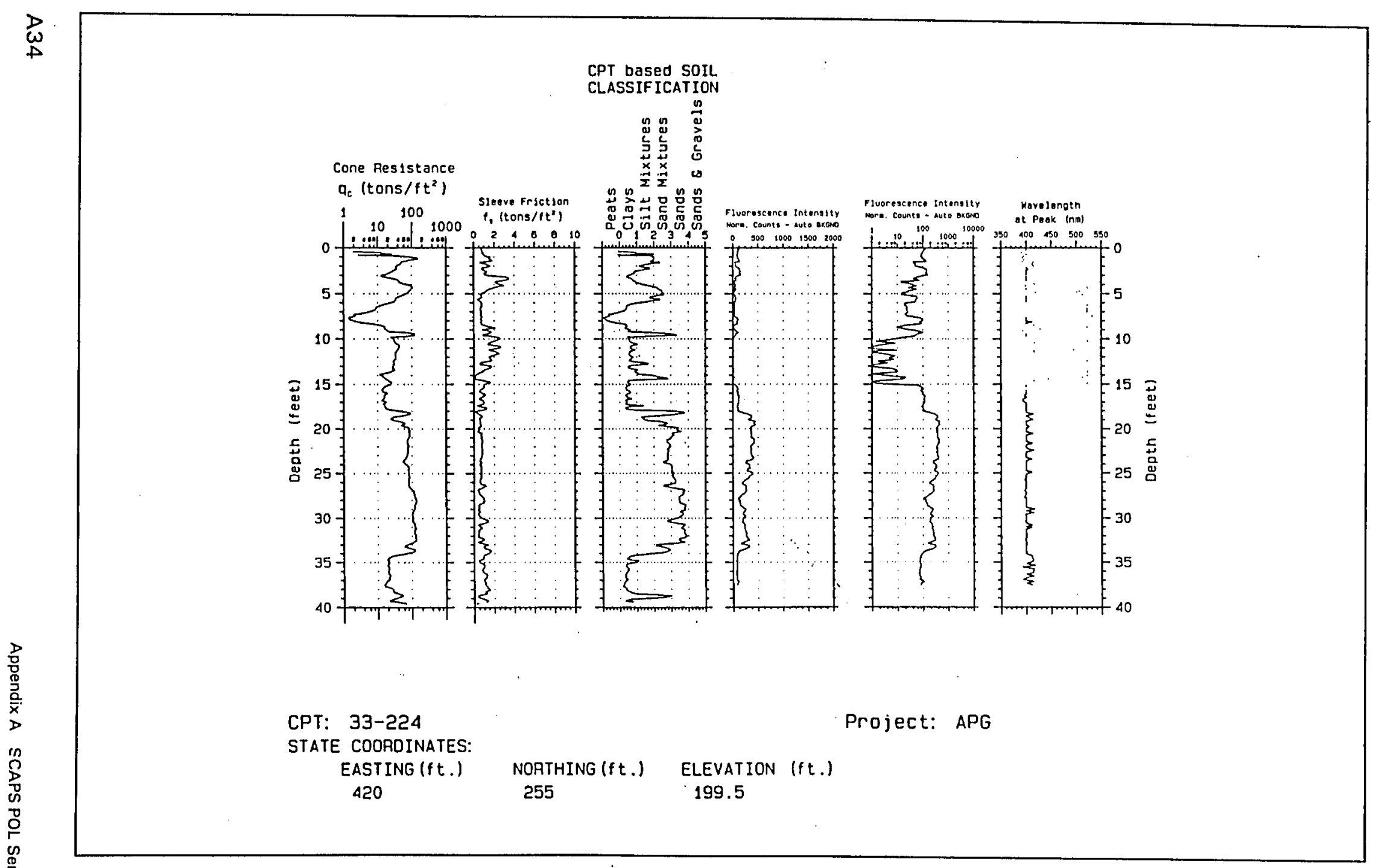

Figure A33. CPT 33-224, Aberdeen Proving Ground 


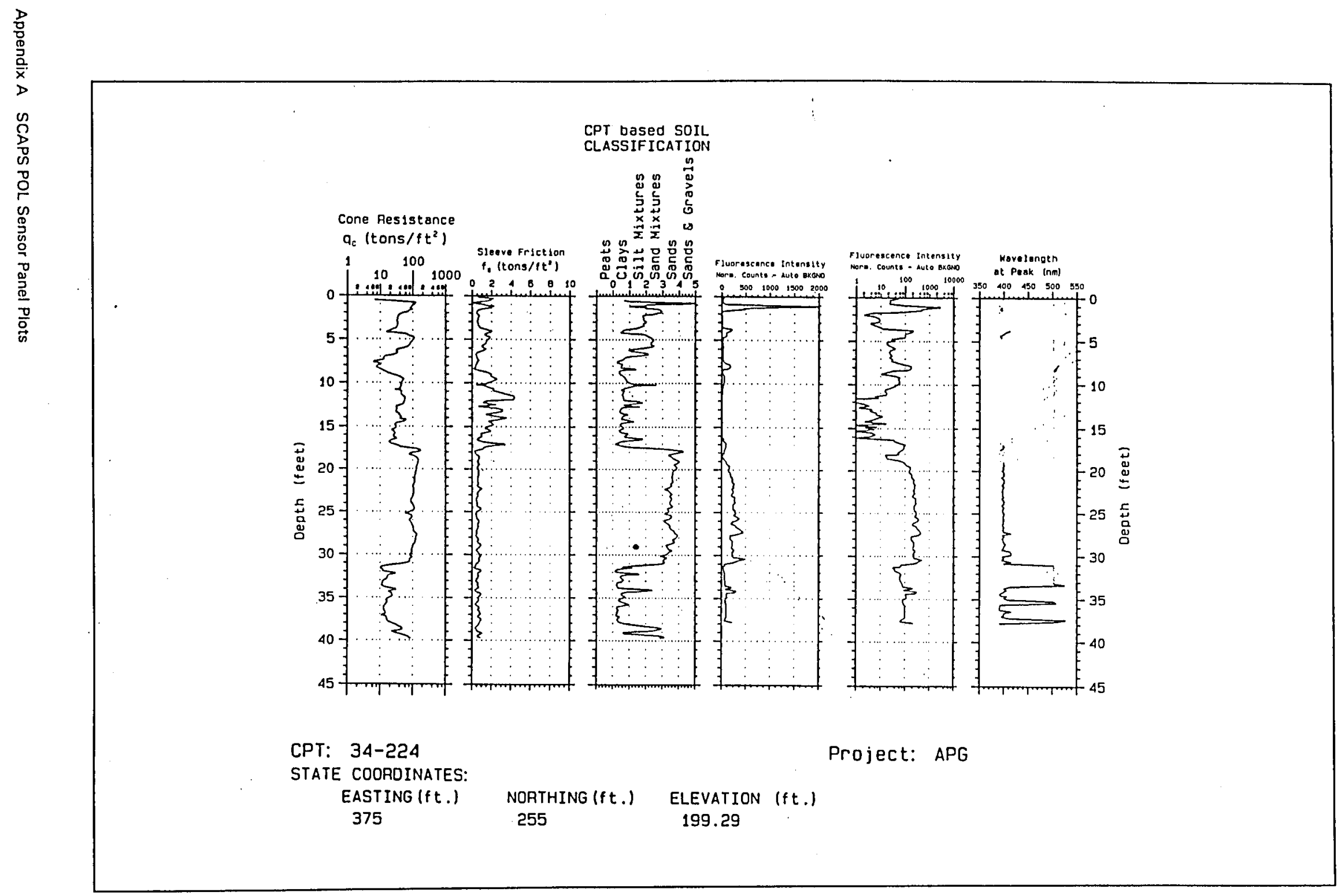

$\underset{\sim}{\stackrel{D}{w}}$ Figure A34. CPT 34-224, Aberdeen Proving Ground 


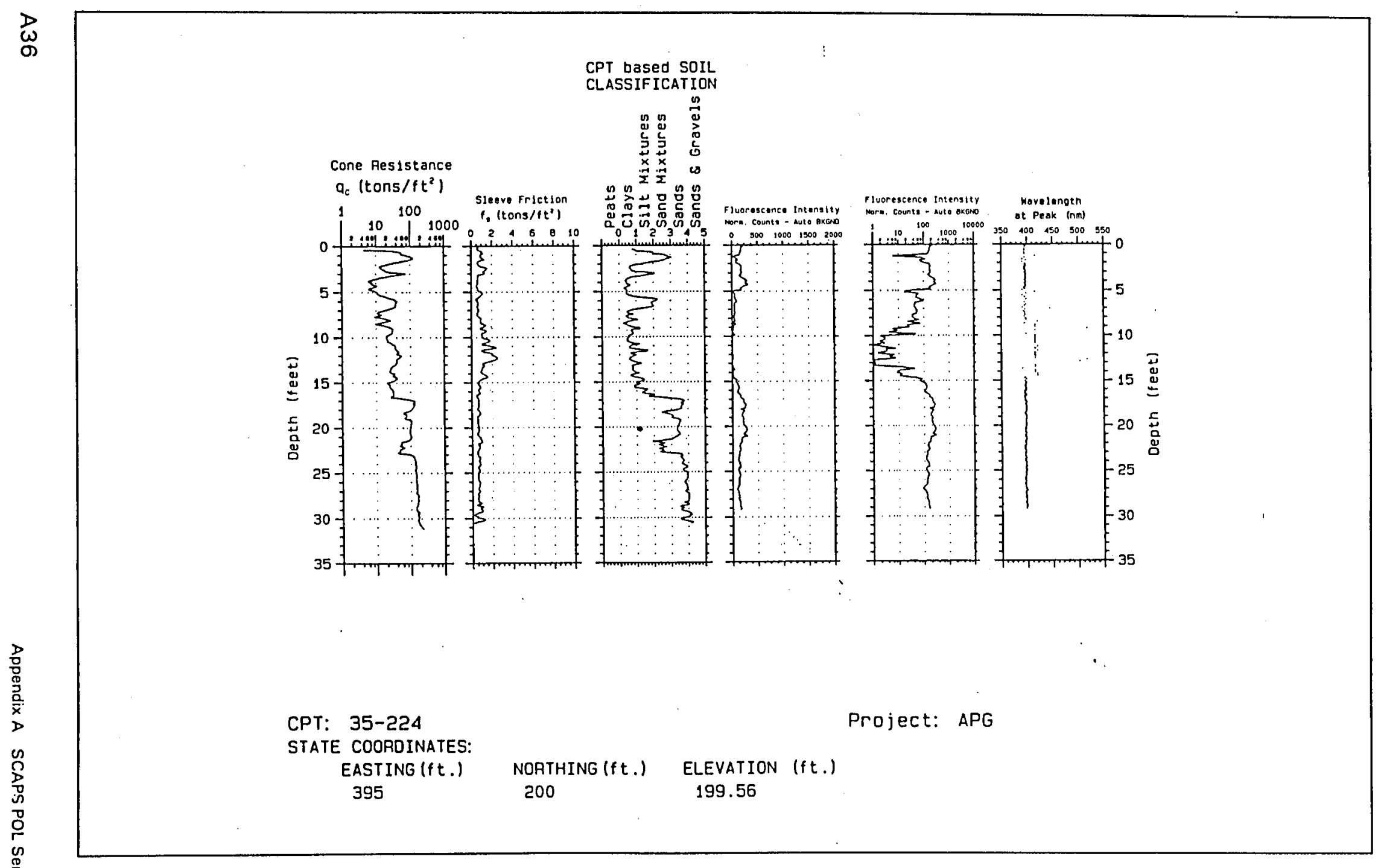

Figure A35. CPT 35-224, Aberdeen Proving Ground 


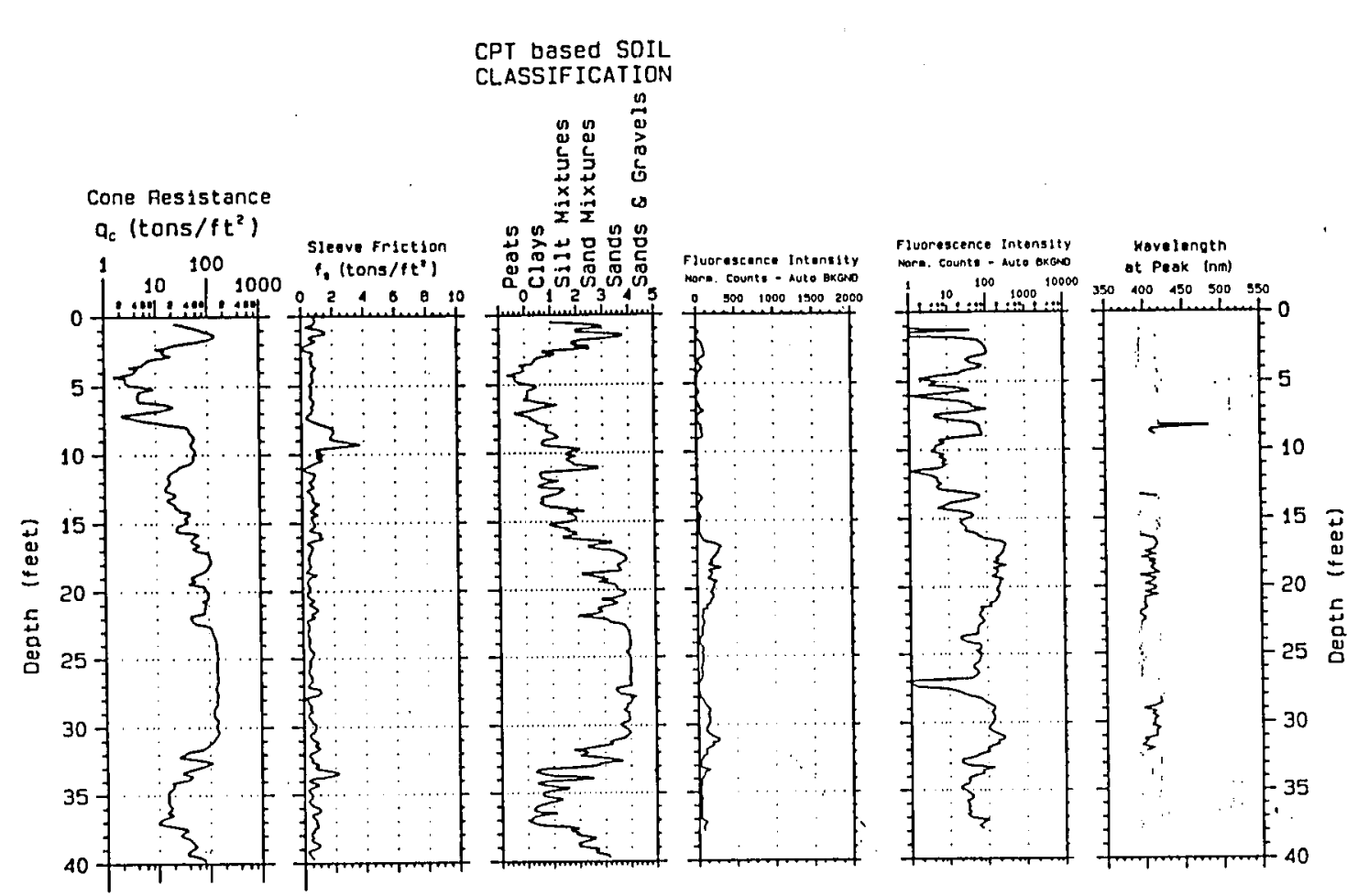

CPT: 36-224

STATE COOADINATES:

EASTING (ft.) NORTHING $(f t$.$) ELEVATION (f t$.

395

190

Project: APG 


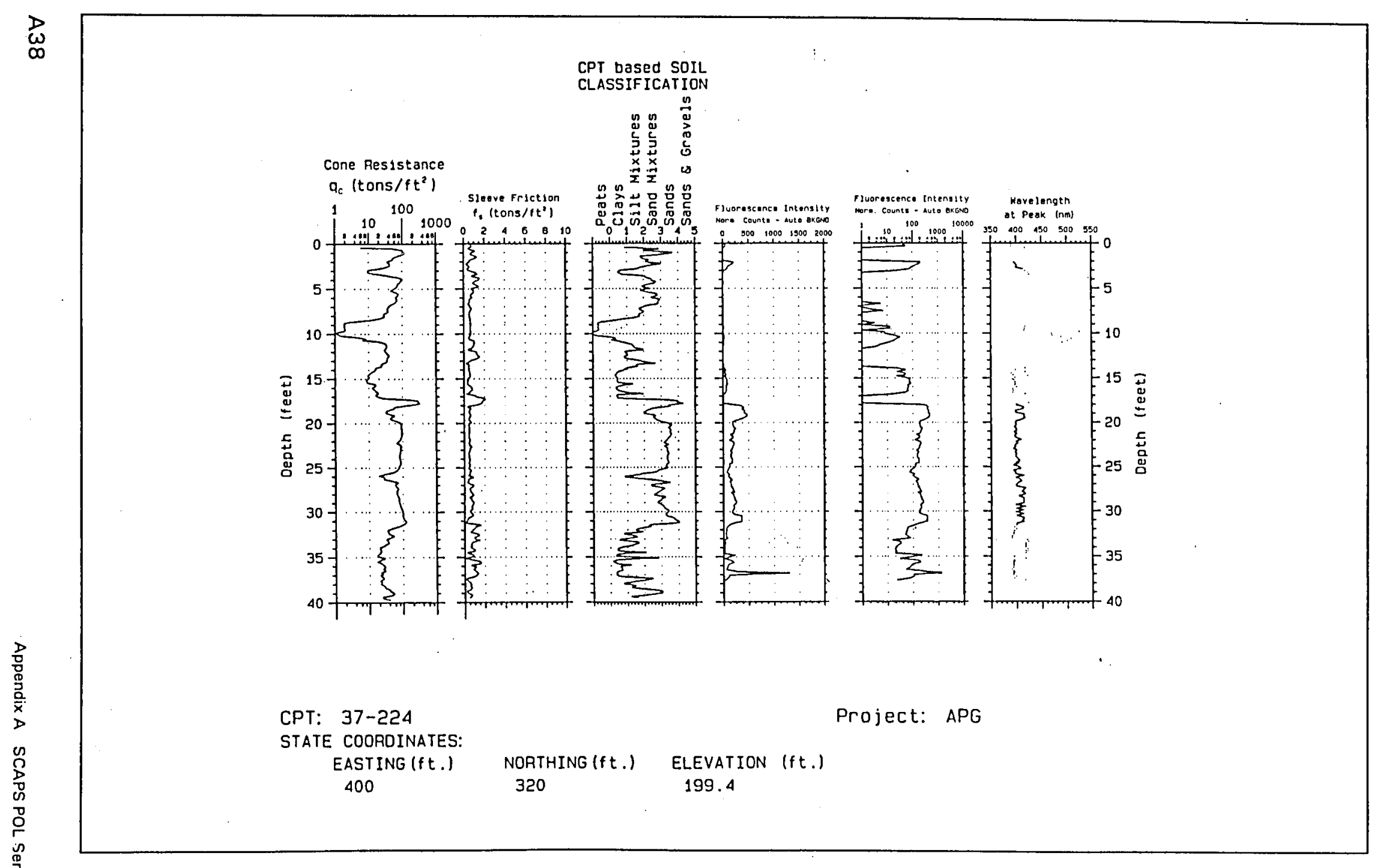

Figure A37. CPT 37-224, Aberdeen Proving Ground 


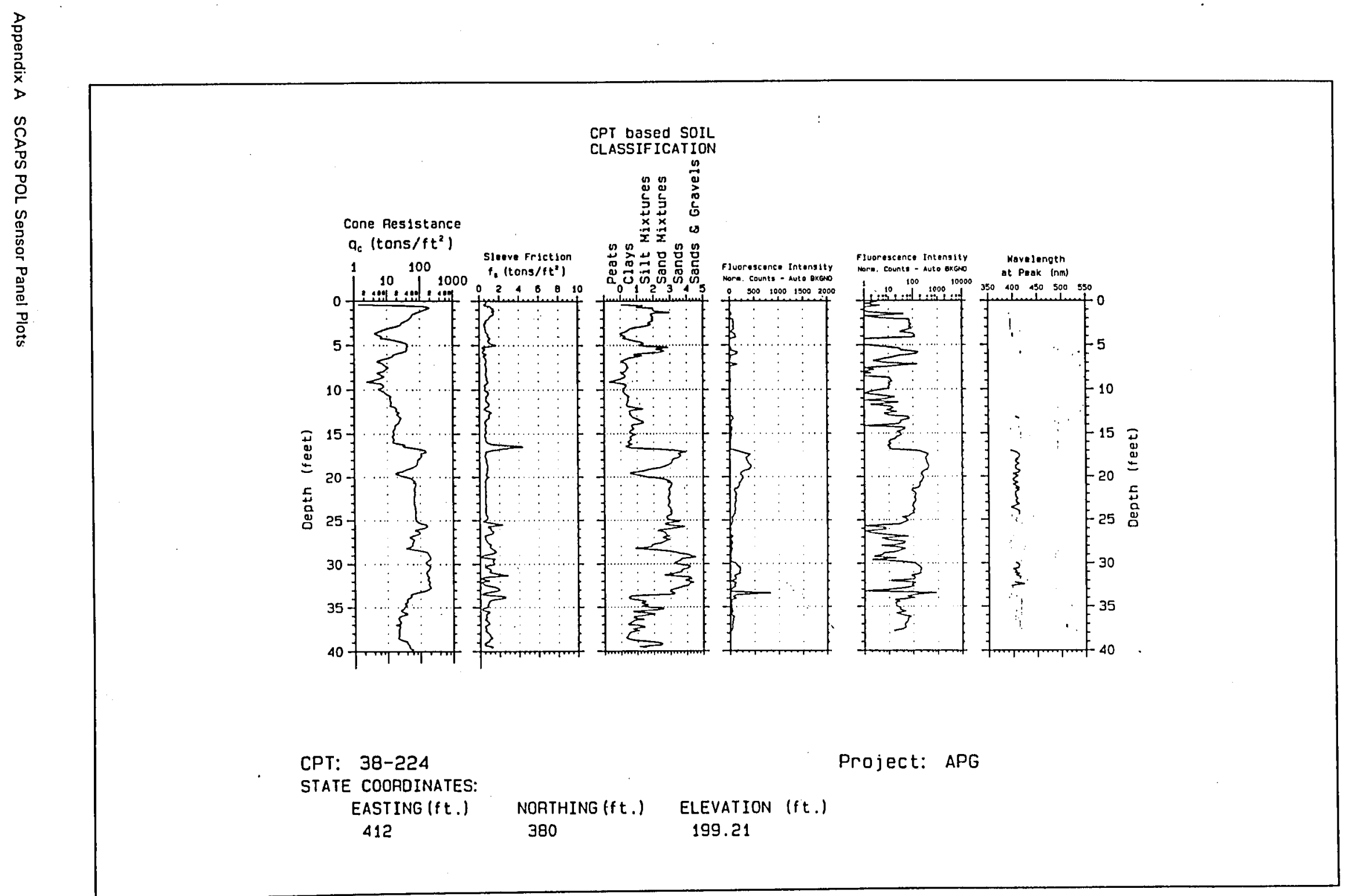

$\vec{\omega}$
0

Figure A38. СРT 38-224, Aberdeen Proving Ground 


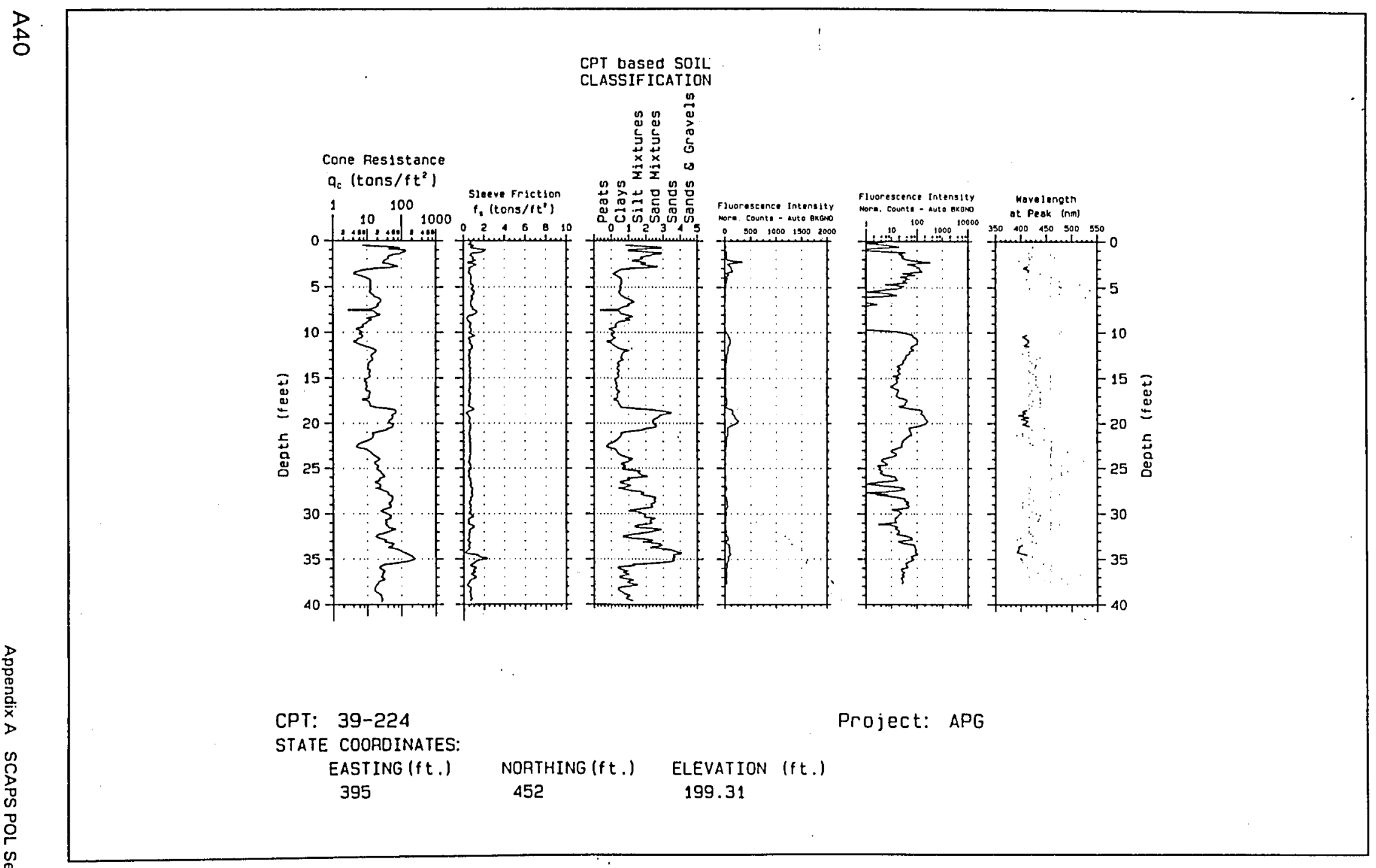

Figure A39. CPT 39-224, Aberdeen Proving Ground 


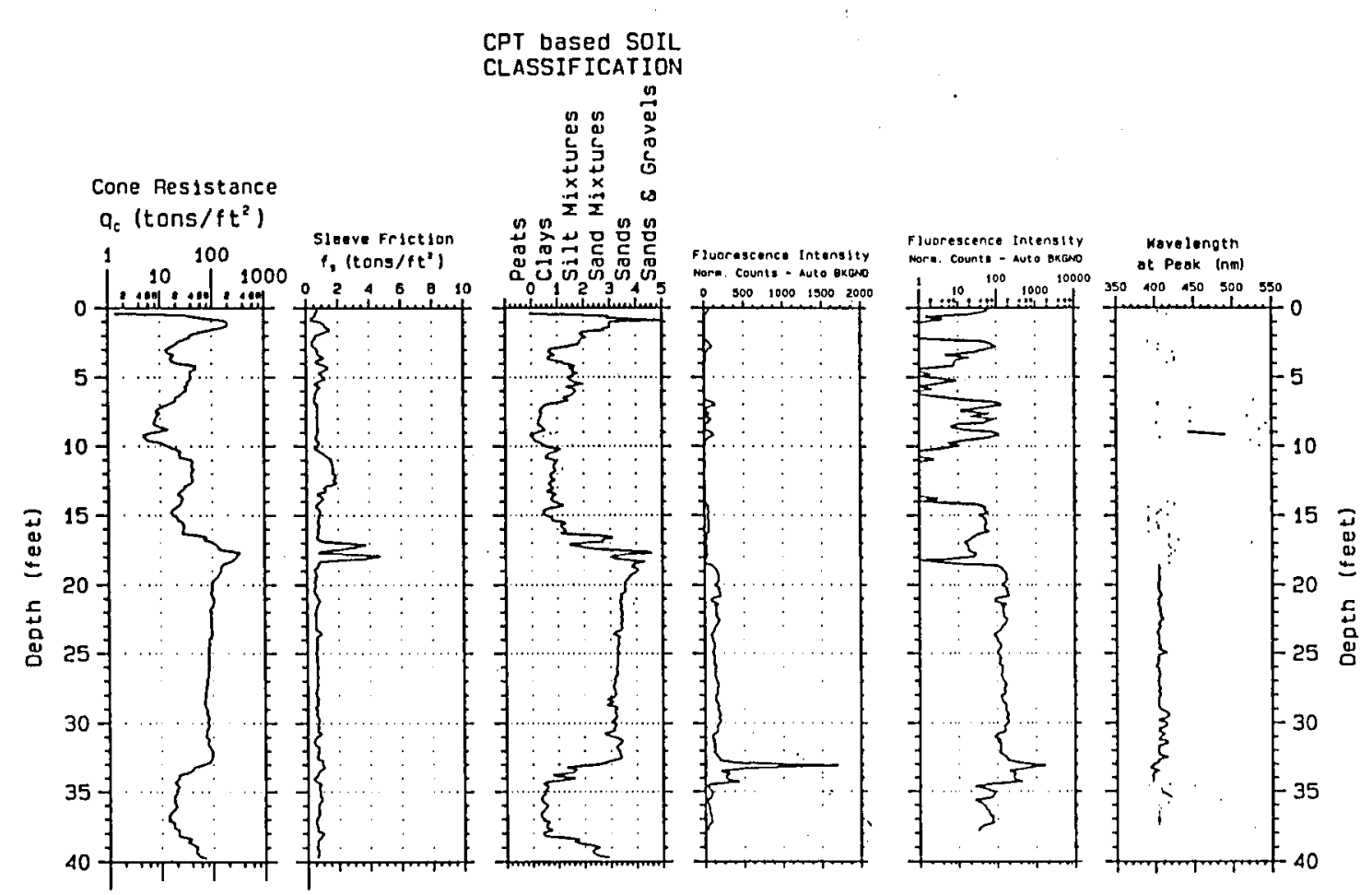

CPT: $40-225$

STATE COORDINATES:

$\begin{array}{ccc}\text { EASTING }(\mathrm{ft} .) & \text { NORTHING }(\mathrm{ft} .) & \text { ELEVATION } \\ 455 & 330 & 199.6\end{array}$

Project: APG

330

199.6 


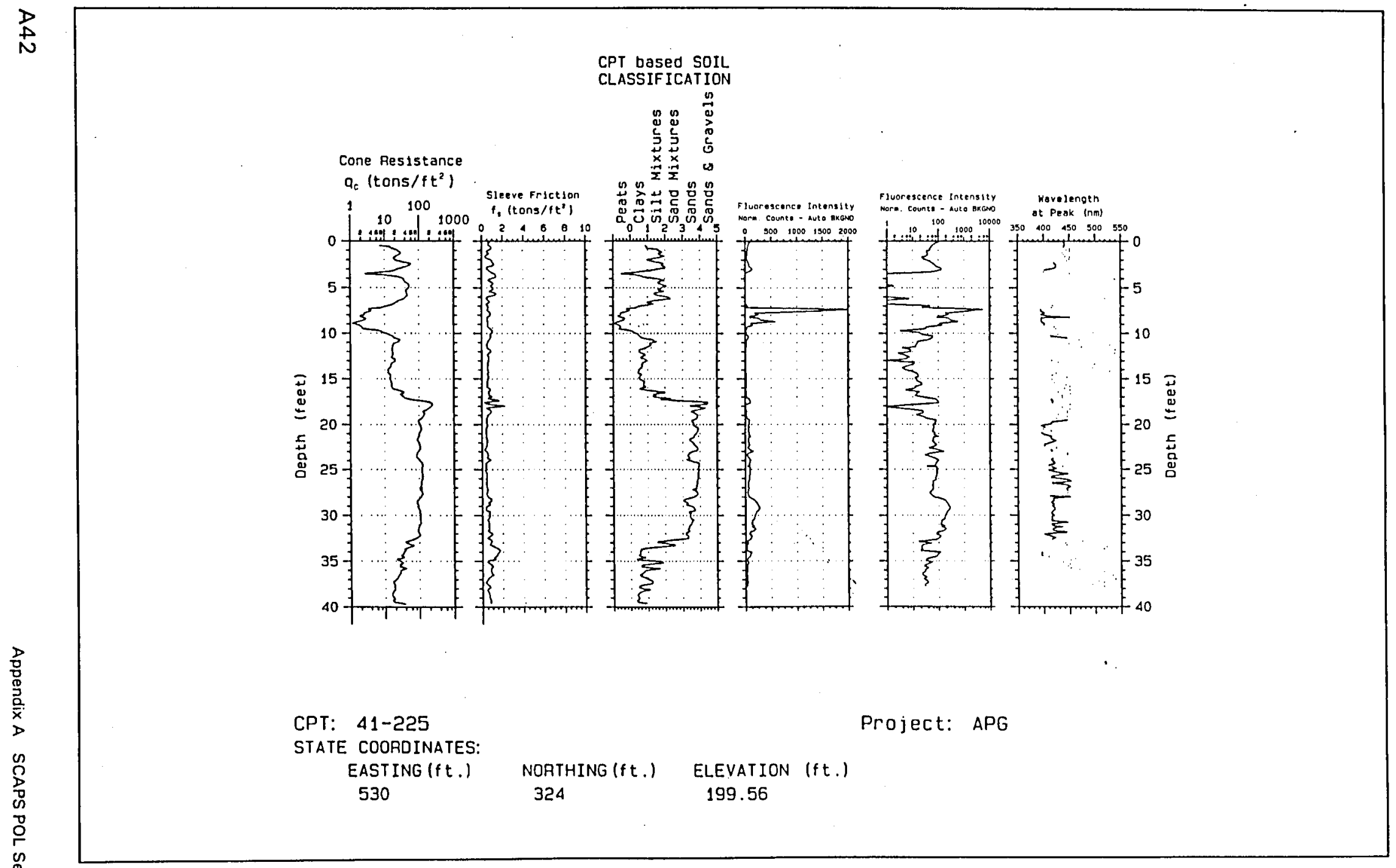

Figure A41. CPT 41-225, Aberdeen Proving Ground 


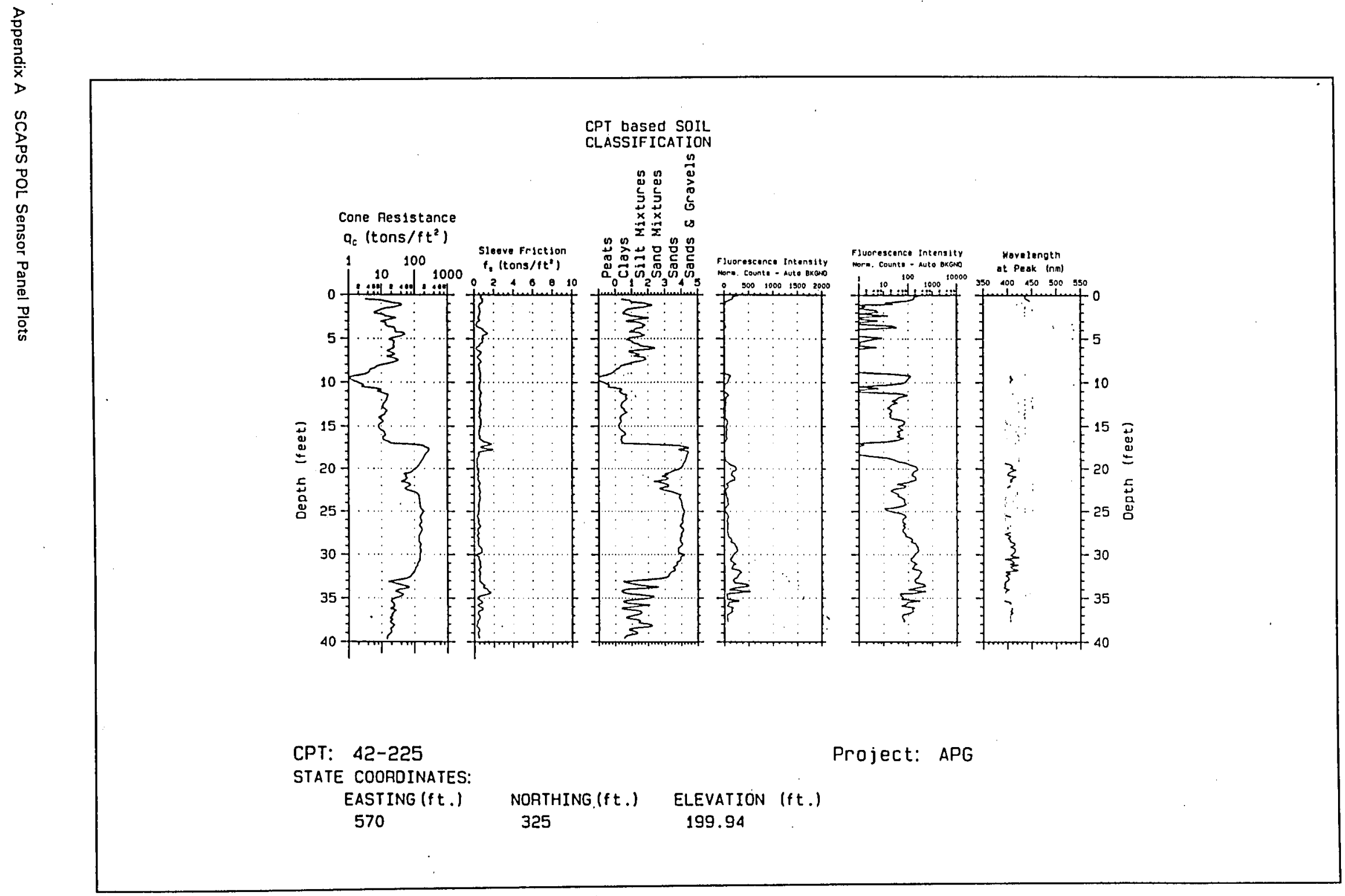

Figure A42. CPT 42-225, Aberdeen Proving Ground 


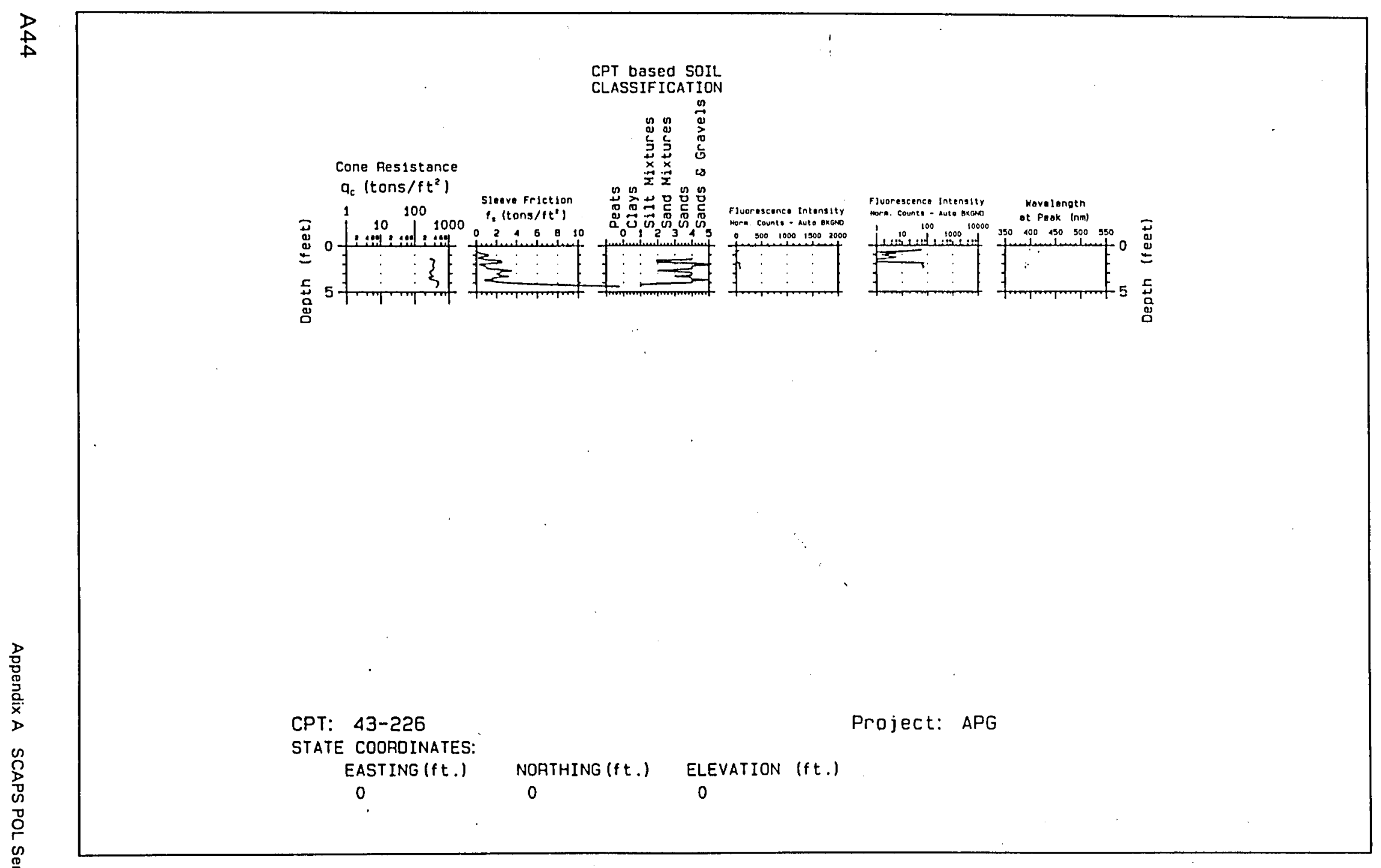

Figure A43. CPT 43-226, Aberdeen Proving Ground 


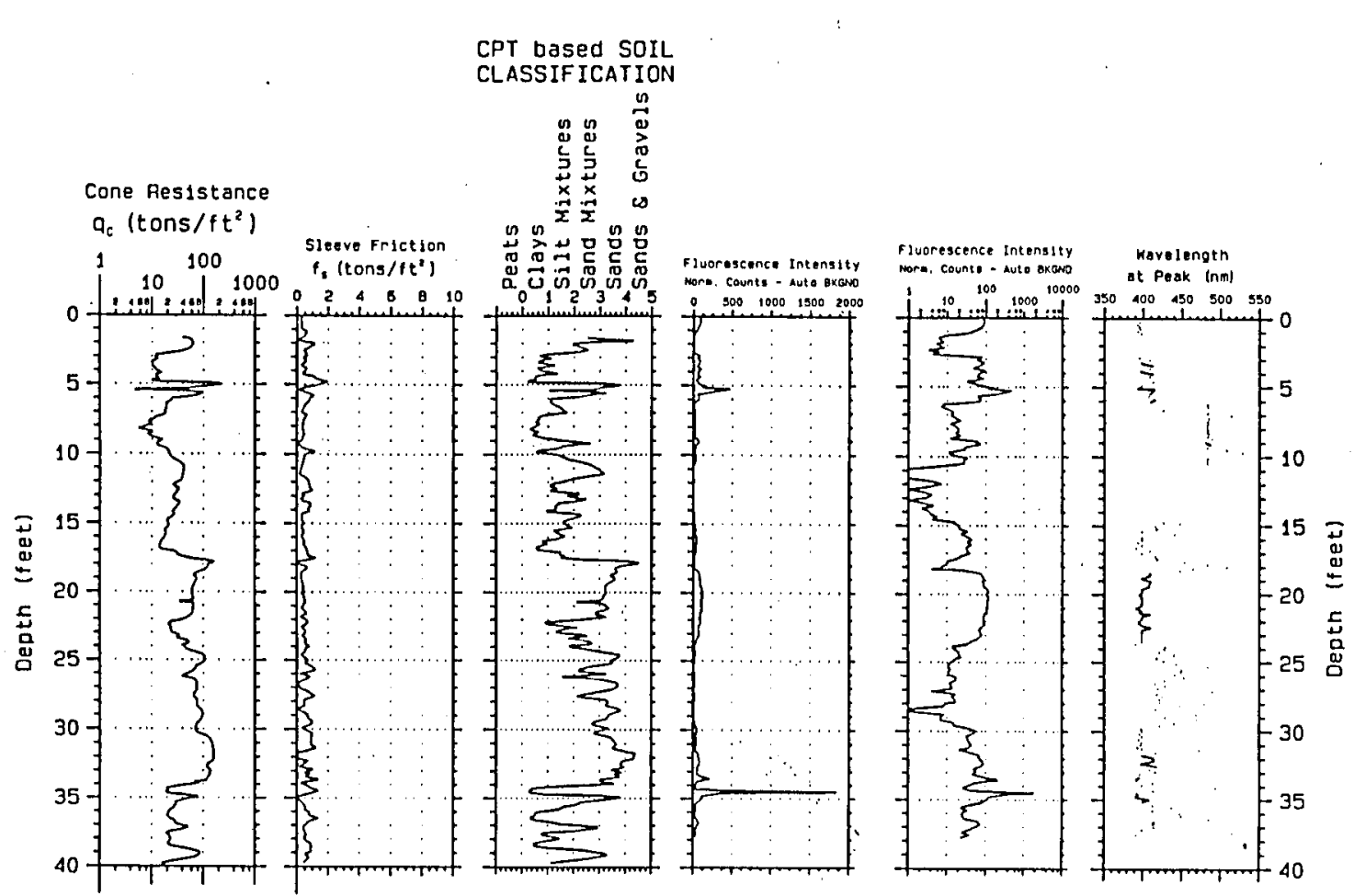

СРТ: 44-226

STATE COORDINATES: EASTING ( $\mathrm{ft}$.)

NORTHING ( $f t$.) ELEVATION (ft.)

233

291

199.43

Figure A44. CPT 44-226, Aberdeen Proving Ground

Project: APG 


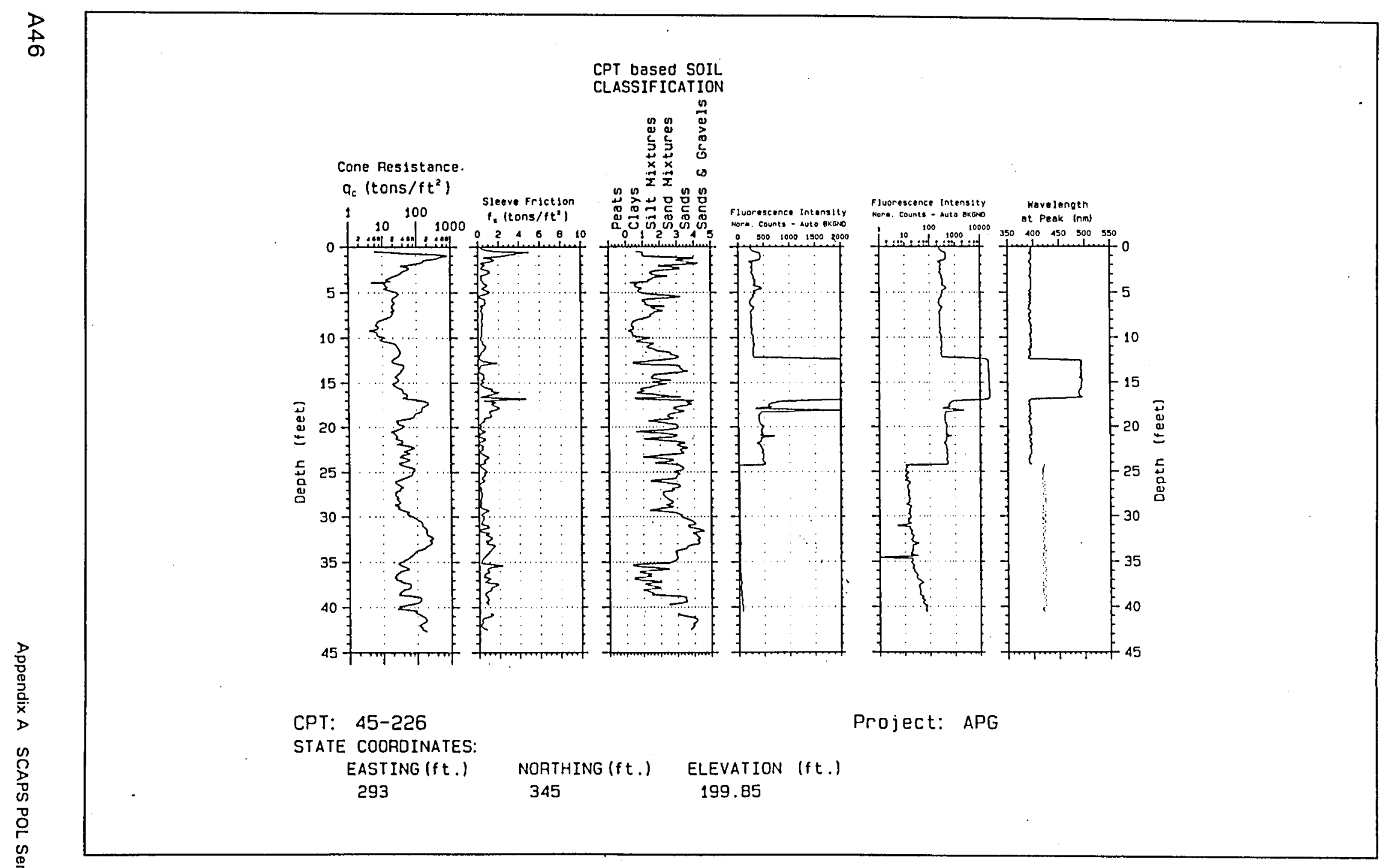

Figure A45. CPT 45-226, Aberdeen Proving Ground 
CPT based SOIL

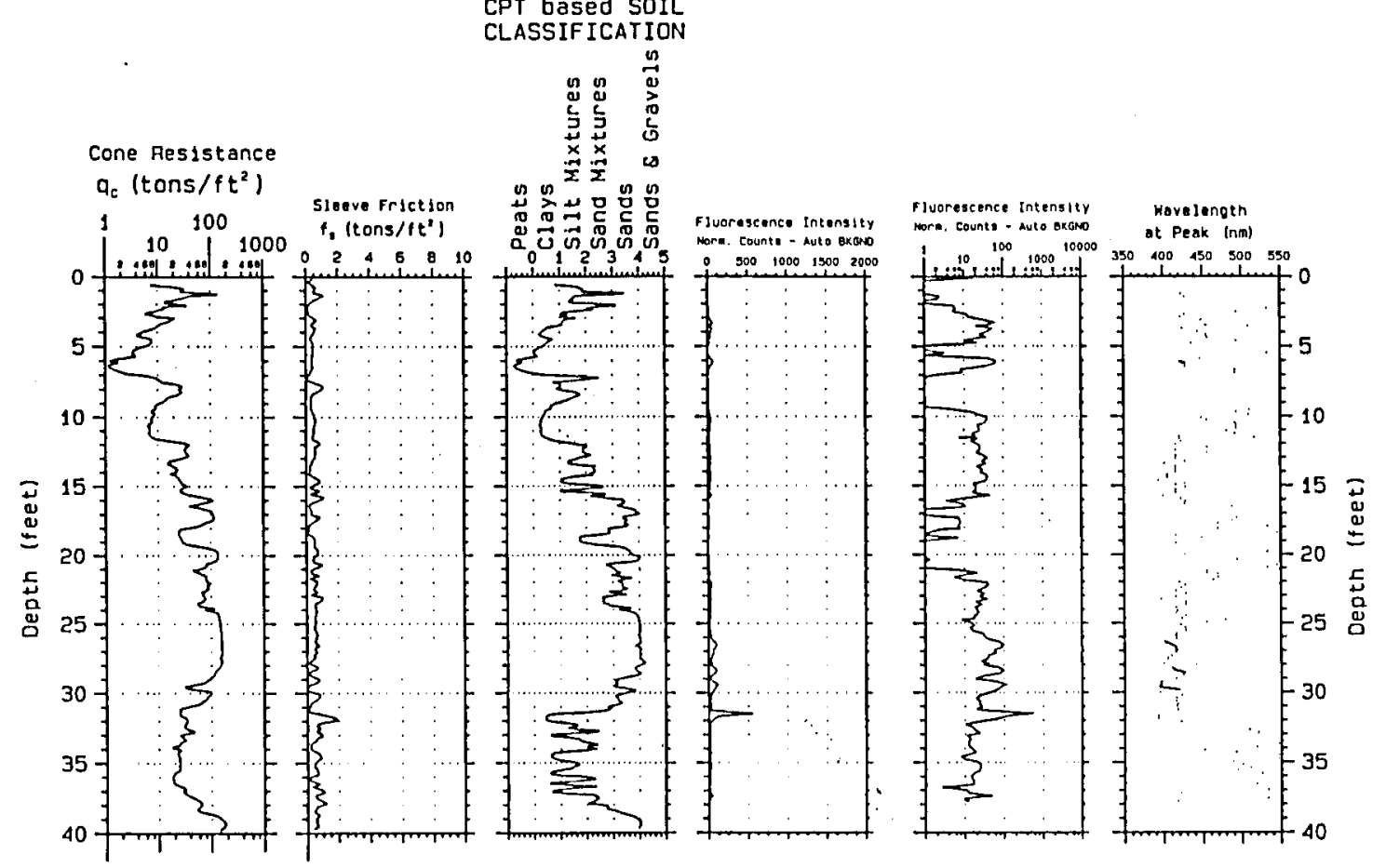

CPT: $46-227$

STATE COORDINATES:

EASTING (ft.) NORTHING (ft.) ELEVATION (ft.)

340

145

Project: APG

8

Figure A46. CPT 46-227, Aberdeen Proving Ground 


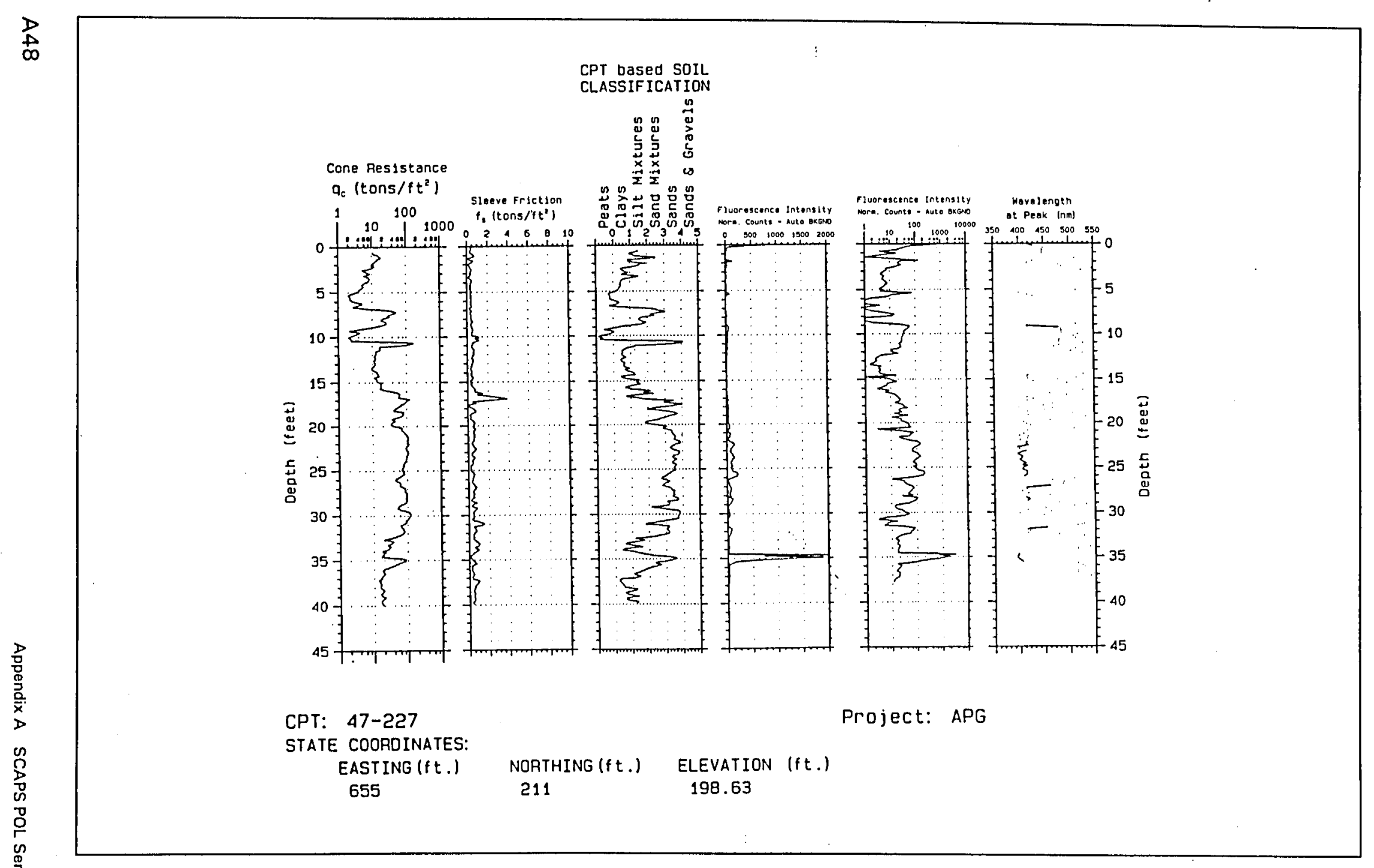

Figure A47. CPT 47-227, Aberdeen Proving Ground 


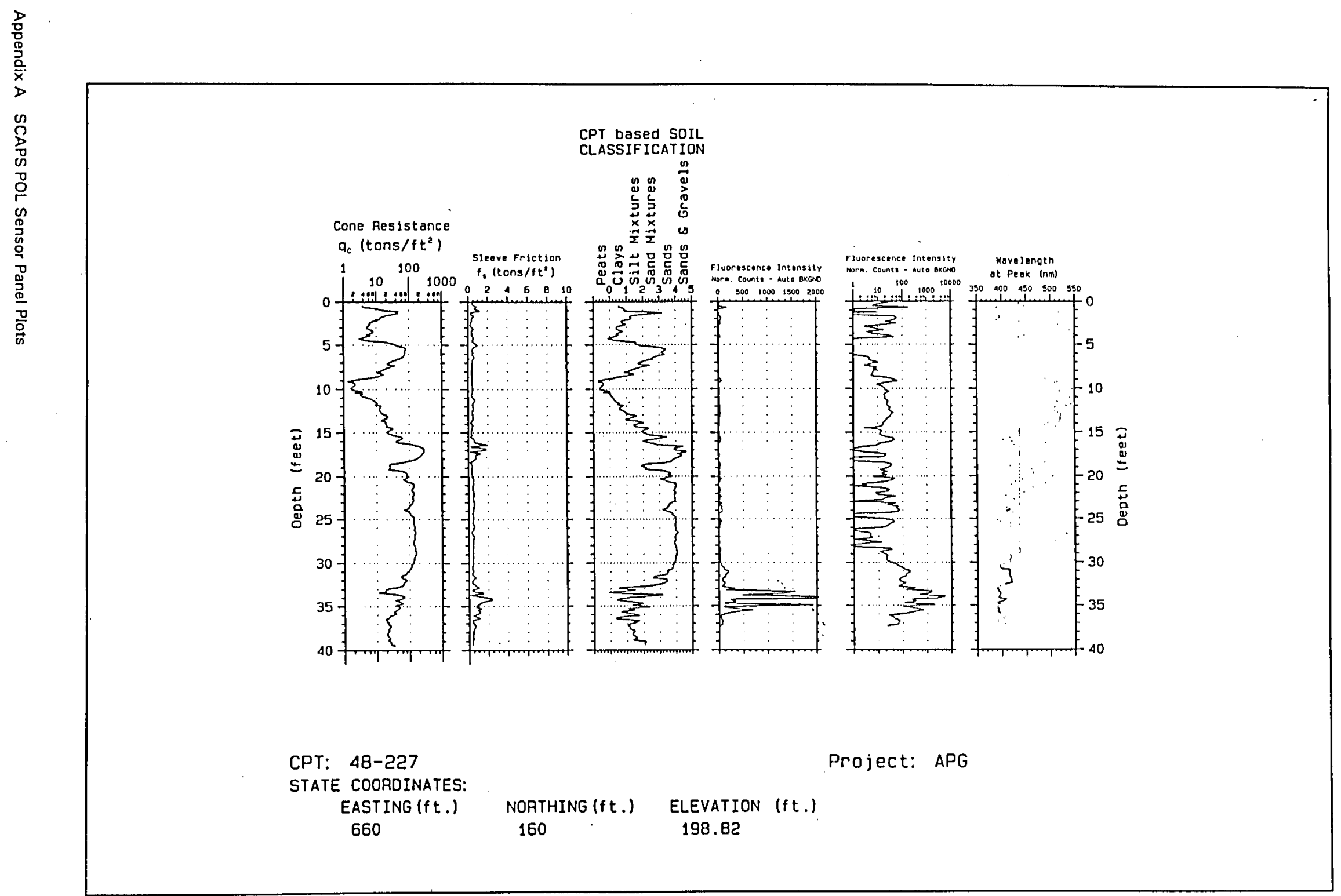

$\underset{6}{P}$

Figure A48. CPT 48-227, Aberdeen Proving Ground 


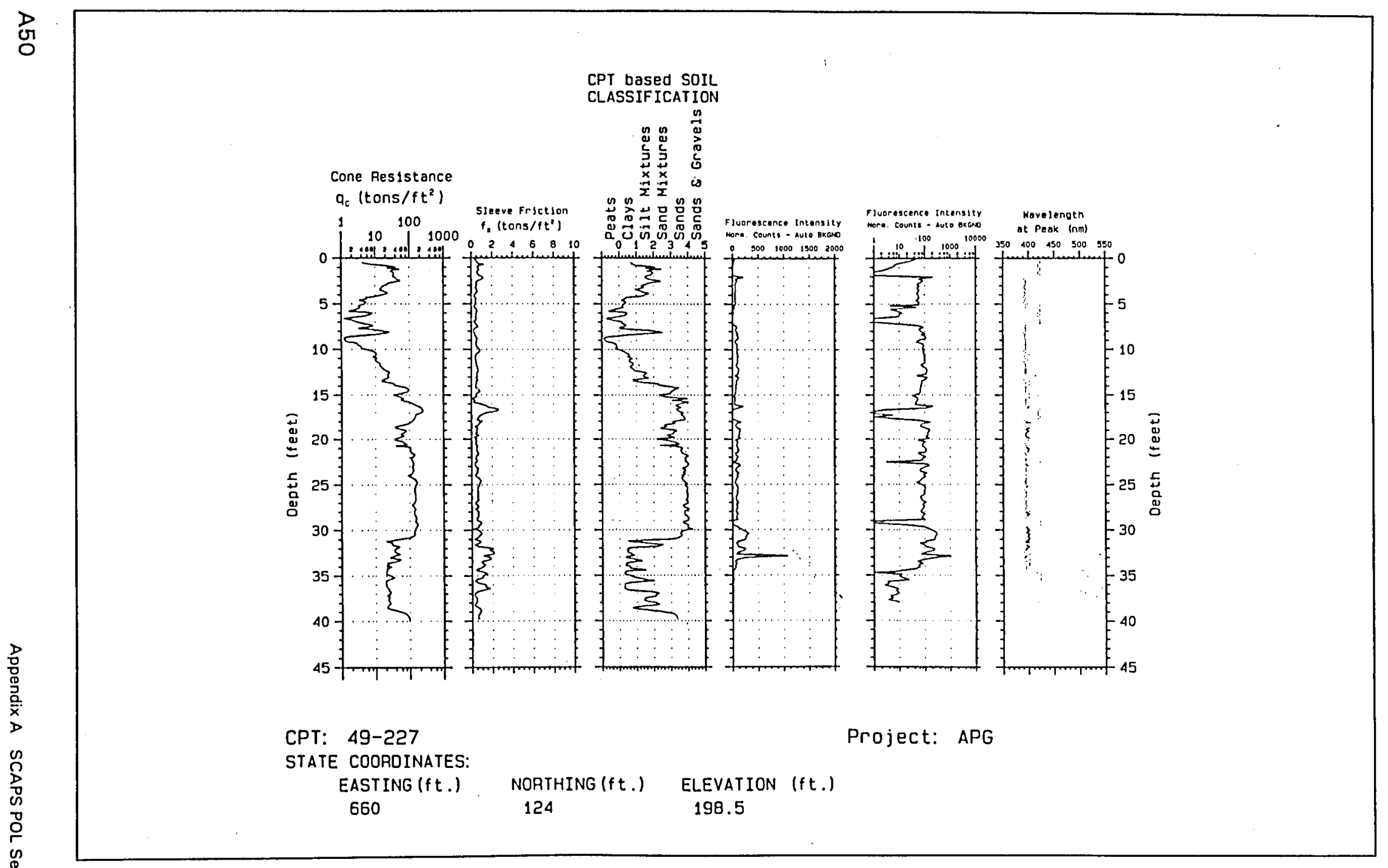

Figure A49. CPT 49-227, Aberdeen Proving Ground 


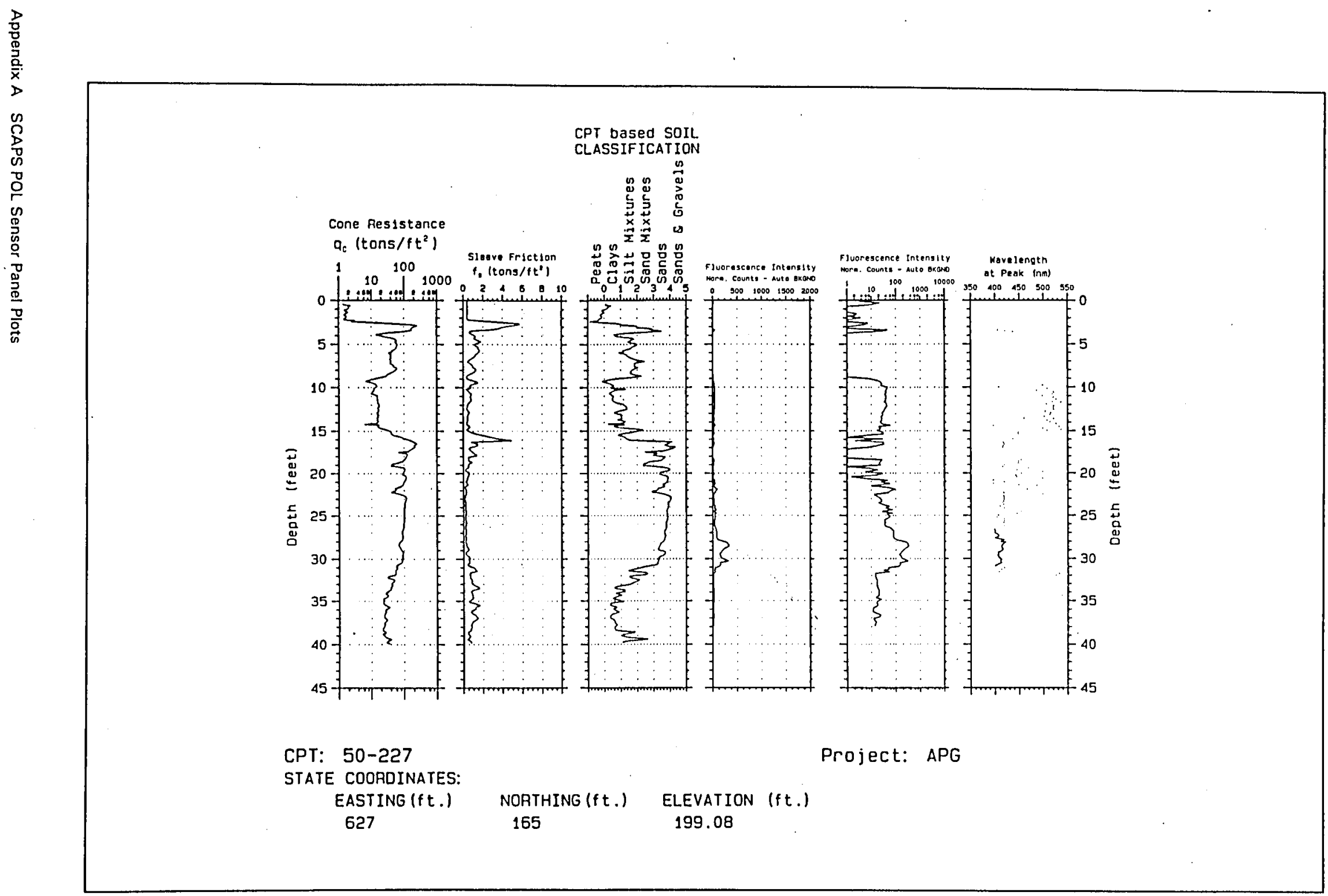




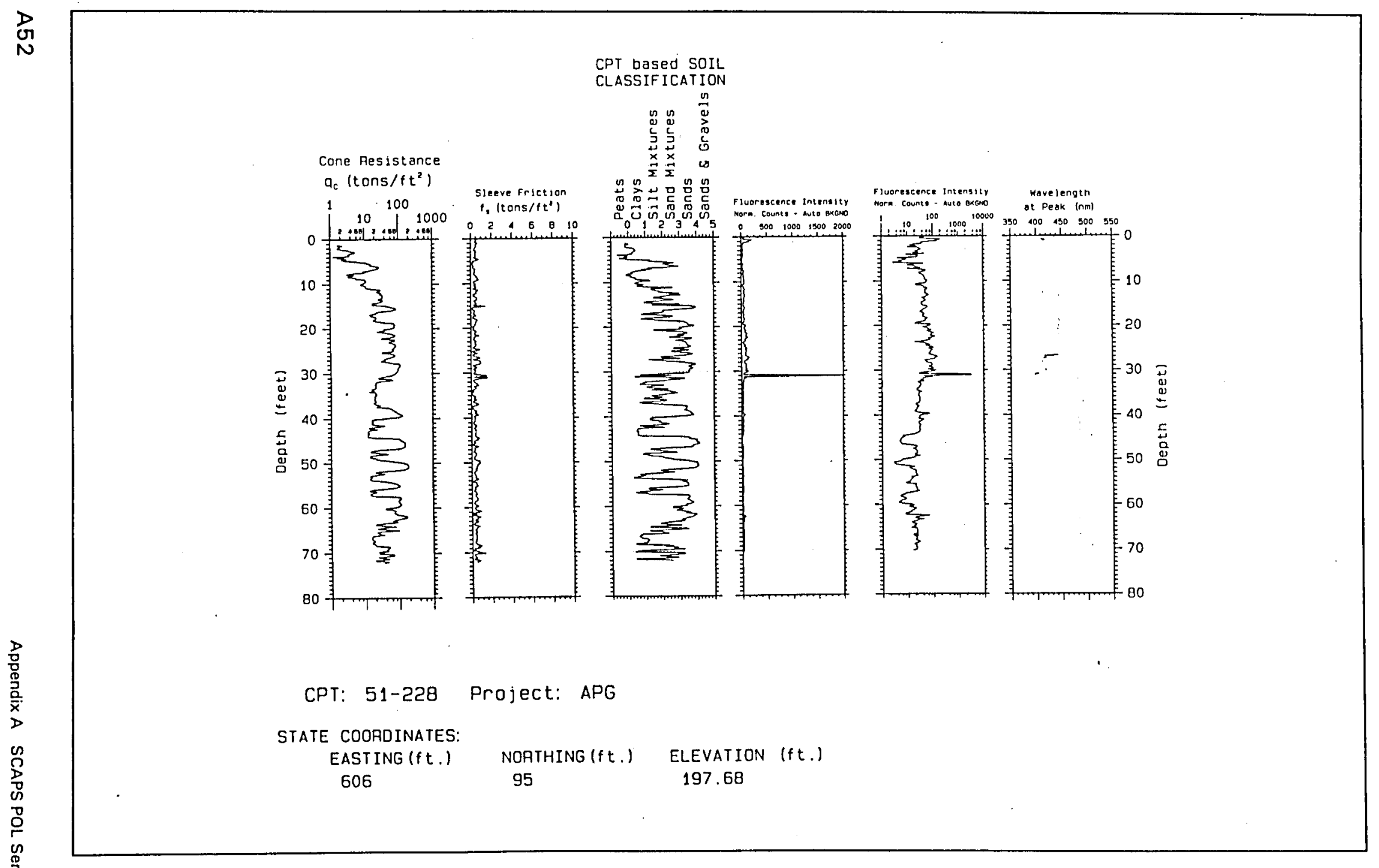

Figure A51. CPT 51-228, Aberdeen Proving Ground 


\section{Appendix B \\ List of Demonstration \\ Participants}




\begin{tabular}{|c|c|c|}
\hline \multicolumn{3}{|c|}{$\begin{array}{l}\text { APG SCAPS DEMO } \\
01 \text { and } 02 \text { March } 1995\end{array}$} \\
\hline Name & Organization & Phone \\
\hline Jennifer Cook & USAEC & \\
\hline Dean Hutchins & USAEC & $410-671-1527$ \\
\hline Gary R. Perry & USAEC & $410 \cdot 612.6855$ \\
\hline Vivian Graham & USAEC & 410.612 .6869 \\
\hline Rurik Loder & DSHE & $410-621-2945$ \\
\hline Chris Jacobs & DSHE & $410-621-2945$ \\
\hline Tim McNamara & $\begin{array}{l}\text { APG H, S \& Env } \\
\text { Branch Chief }\end{array}$ & \\
\hline Paul Cerieza & $\begin{array}{l}\text { MD Dept. of the Environment } \\
\text { Oil Control Program }\end{array}$ & $410-631-3442$ \\
\hline Naren Desai & APG, DSHE & $410-671-4569$ \\
\hline Rurik Loder & APG, DSHE & $410-671-4569$ \\
\hline Stan Swartzel & WES & $601-634-3326$ \\
\hline Melinda Pringle & DSHE & $410-278-4099$ \\
\hline Janice Martinez & DSHE & $410-278-7979$ \\
\hline Dan Hitching & DSHE & $410-278-7001$ \\
\hline Ray McDermott & DSHE & $410-278-9949$ \\
\hline Karen Baker & AEC & \\
\hline Ted Henry & APGSCC/Univ. of MD & $410-706-8196$ \\
\hline Amy Yorks & APGSCC/Univ, of MD & $410-706-8196$ \\
\hline Katherine Squibb & Univ. of MD/APGSCC & $410-455-6311$ \\
\hline Ron Jackson & USAEC & $410-612-6849$ \\
\hline
\end{tabular}




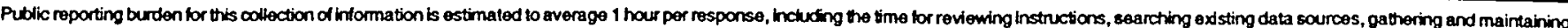

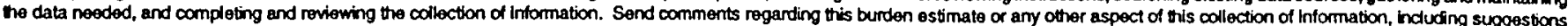

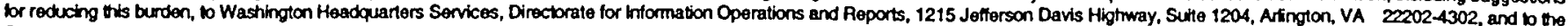
Office of Management and Budget, Paperwork Reduction Project (0704-0188), Wastington, DC 20503.

\begin{tabular}{|c|c|c|}
\hline 1. AGENCY USE ONLY (Leave blank) & $\begin{array}{l}\text { REPORT DATE } \\
\text { November } 1996\end{array}$ & $\begin{array}{l}\text { 3. REPORT TYPE AND DATES COVERED } \\
\text { Final report }\end{array}$ \\
\hline
\end{tabular}

4. TITLE AND SUBTtTLE

Site Characterization and Analysis Penetrometer System (SCAPS) Field Inves-

5. FUNDING NUMBERS

tigation at the Building 4020 Site, Aberdeen Proving Ground, Maryland

6. AUTHOR(S)

William M. Davis, Landris T. Lee, Jr., Jeff F. Powell

7. PERFORMING ORGANIZATION NAME(S) AND ADDRESS(ES)

U.S. Army Engineer Waterways Experiment Station

3909 Halls Ferry Road

Vicksburg, MS 39180-6199

8. PERForming ORganization REPORT NUMBER

Technical Report EL-96-17

9. SPONSORING/MONITORING AGENCY NAME(S) AND ADDRESS(ES)

U.S. Army Corps of Engineers

10. SPONSORING/MONITORING

Washington, DC 20314-1000 AGENCY REPORT NUMBER

11. SUPPLEMENTARY NOTES

Available from National Technical Information Service, 5285 Port Royal Road, Springfield, VA 22161.

12a. DISTRIBUTIONAVAILABILTTY STATEMENT

Approved for public release; distribution is unlimited.

12b. DISTRIBUTION CODE

13. ABSTRACT (Maximum 200 words)

The U.S. Army Engineer Waterways Experiment Station site charaterization and analysis penetrometer system (SCAPS) investigated suspected fuel leaks from removed underground storage tanks at the Building 4020 site on Aberdeen Proving Ground, Maryland. Fifty-one penetrations were made with the SCAPS soil sensor and the laser-induced fluorescence sensor during a period of 12 working days. The suspected contamination was detected, and its limited extent was delineated.

14. SUBJECT TERMS

Cone penetrometer

Contamination plume mapping

Field and laboratory verification
Laser-induced fluorometer

POL contamination

Soil stratigraphy
15. NUMBER OF PAGES

92

16. PRICE CODE
17. SECURITY CLASSIFICATION OF REPORT UNCLASSIFIED
18. SECURITY CLASSIFICATION OF THIS PAGE

UNCLASSIFIED
19. SECURITY CLASSIFICATION OF ABSTRACT 
